\title{
INFLUÊNCIA DA TEMPERATURA, TEMPO E CONCENTRAÇÃO DE PECTINASE NA TEXTURA, RENDIMENTO E CARACTERÍSTICAS FÍSICO-QUÍMICAS DA MANDIOCA (Manihot esculenta C.) DURANTE FERMENTAÇÃO
}

\author{
MARILISA FLAVIA PEREIRA DI-TANNO
}

Dissertação apresentada à Escola Superior de Agricultura "Luiz de Queiroz", Universidade de São Paulo, para obtenção de título de Mestre em Ciências, Área de Concentração: Ciência e Tecnologia de Alimentos.

P I R A C I C A B A

Estado de São Paulo- Brasil

Outubro - 2001 


\title{
INFLUÊNCIA DA TEMPERATURA, TEMPO E CONCENTRAÇÃO DE PECTINASE NA TEXTURA, RENDIMENTO E CARACTERÍSTICAS FÍSICO-QUÍMICAS DA MANDIOCA (Manihot esculenta C.) DURANTE FERMENTAÇÃO
}

\author{
MARILISA FLAVIA PEREIRA DI-TANNO \\ Engenheiro Agrônomo
}

Orientador: Prof. Dr. TOBIAS JOSÉ BARRETO DE MENEZES

\begin{abstract}
Dissertação apresentada à Escola Superior de Agricultura "Luiz de Queiroz", Universidade de São Paulo, para obtenção de título de Mestre em Ciências, Área de Concentração: Ciência e Tecnologia de Alimentos.
\end{abstract}

P I R A C I C A B A

Estado de São Paulo- Brasil

Outubro - 2001 
Dados Internacionais de Catalogação na Publicação (CIP) DIVISÃO DE BIBLIOTECA E DOCUMENTAÇÃO - ESALQ/USP

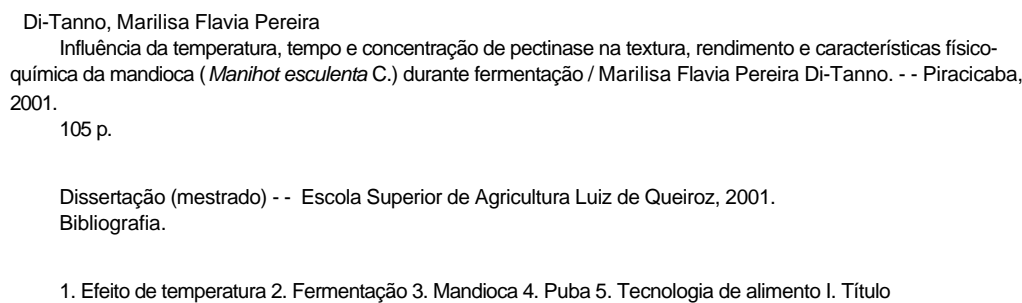




\section{DEDICO}

Aos meus pais:

Benedicto Ney Di-Tanno e Marilia Aparecida Pereira Di-Tanno

pelo amor, educação e apoio sempre.

A minha irmã e cunhado:

Mariney Flávia Pereira Di-Tanno Ramalho e Alexandre Figueiredo Ramanho

pela amizade, incentivo, compreensão e sugestões em todos os momentos.

Aos meus queridos sobrinhos:

Ana Carolina Di-Tanno Ramalho e

Bruno Di-Tanno Ramalho

por me alegrarem o coração e a vida. 


\section{AGRADECIMENTOS}

À DEUS pela vida e por todos que dela participam.

Ào Prof. Dr. Tobias José Barreto de Menezes pela oportunidade do mestrado e orientação.

À Profa Dra Silene Bruder Silveira Sarmento, pela prestimosa colaboração, utilização do laboratório, apoio e sugestões oferecidas ao longo do trabalho.

À CAPES pela concessão da bolsa de estudos.

À empresa Novo Nordisk Ferment Ltd pela doação da enzima, Pectinex ULTRA SP-L, utilizada no experimento.

À Profa Dra Marilia Oetterer pela utilização do laboratório e equipamentos, amizade e conhecimentos adquiridos durante o curso de mestrado.

À técnica de laboratório Carlota Borrali Prudente dos Anjos pela amizade, companhia, incentivo e auxílio na execução do experimento e análises físico-químicas.

Ao funcionário do CIAGRI/Esalq, Marcelo Alves, pela atenção e execução das análises estatísticas.

Às técnicas de laboratório Ivani A. Marcheto Moreno, Juliana Galvão, Roberta T. Rizzo Benato e Maria Fernanda de A. Prado pela amizade e auxílio prestado nos momentos necessários. 
Às Bibliotecárias Beatriz Helena Giongo e Midiam Gustinelli sempre prontas a colaborar na separação e busca do material bibliográfico.

Ao José Camilo Ceratti Viganó pelo amor, companhia, paciência e ajuda nos momentos oportunos.

À amiga Maria Cristina Cabral Garcia pelo apoio, companhia e incentivo desde minha chegada a Piracicaba.

À Patricia Pratti, pela amizade, companheirismo e colaboração desde o início do curso de mestrado.

À amiga Karen Regina Lemos pela ajuda, carinho e atenção nos momentos necessários.

Aos funcionários das Bibliotecas central e setoriais, Seção de Pós-Graduação e aos Coordenadores de Pós-Graduação em Agronomia, Área de Concentração: Ciência e Tecnologia de Alimentos, pelo esclarecimento e condução nas tarefas de atendimento às normas regulamentares que permitiram a apresentação desta dissertação.

Agradeço a todas as pessoas e instituições que de alguma forma, direta ou indireta, colaboraram para a realização deste trabalho. 


\section{SUMÁRIO}

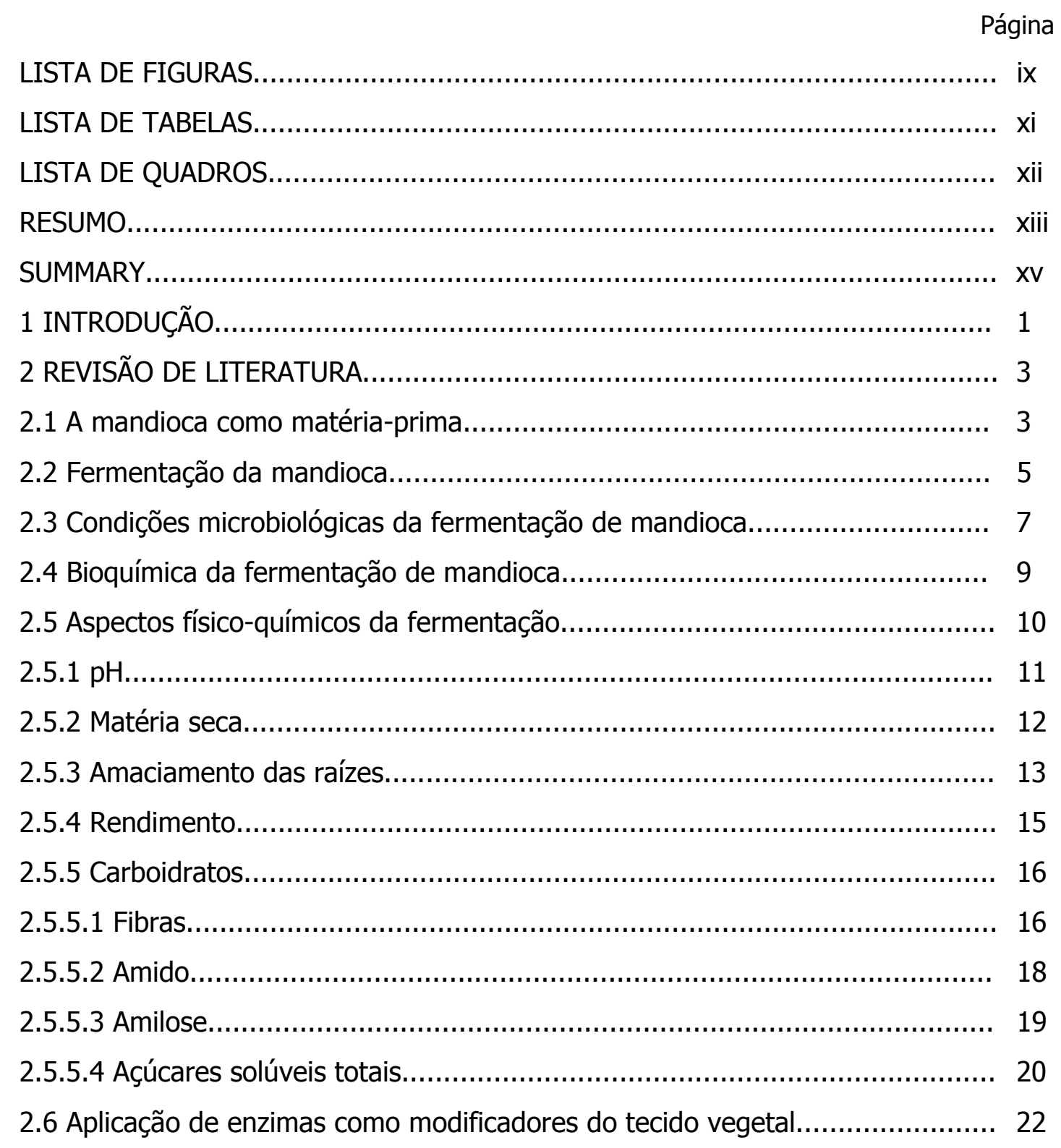


2.7 Temperatura e processo fermentativo.................................................. 24

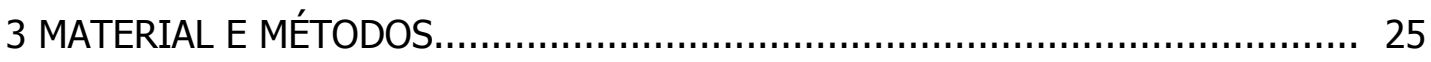

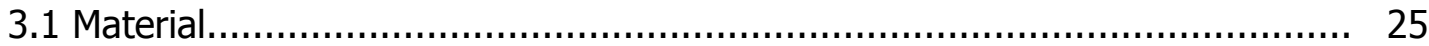

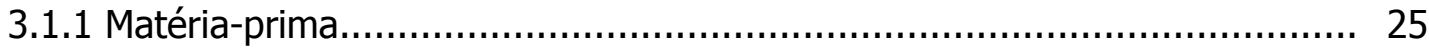

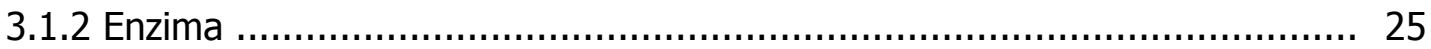

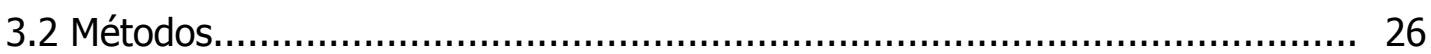

3.2.1 Pubagem convencional e com adição de enzimas.................................... 26

3.2.2 Acondicionamento das amostras....................................................... 30

3.2.3 Textura das raízes de puba............................................................ 32

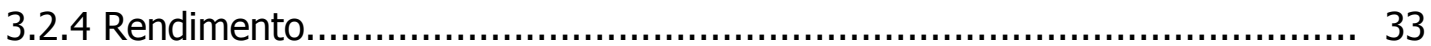

3.2.5 Determinações químicas e físicas.................................................... 33

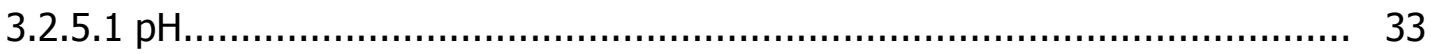

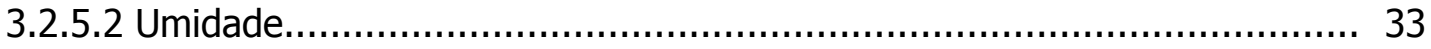

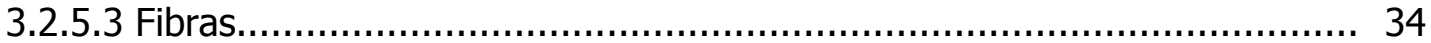

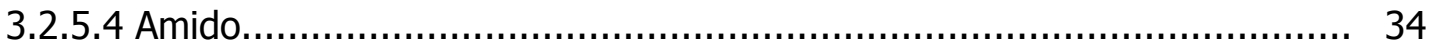

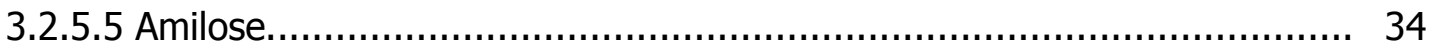

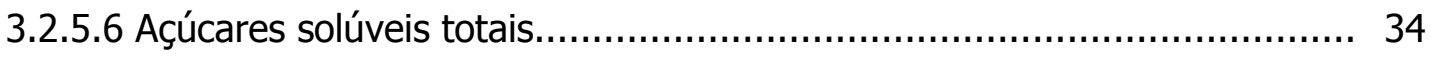

3.2.6 Delineamento experimental....................................................... 34

3.2.6.1 Análise dos resultados................................................................. 35

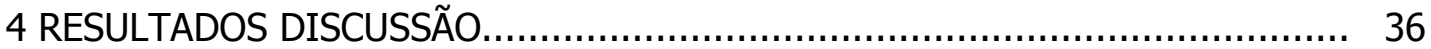

4.1 Composição da matéria-prima............................................................. 36

4.2 Acompanhamento do processo fermentativo........................................ 37

4.2.1 Características da fermentação........................................................... 37

4.2.2 Valores de pH do líquido de fermentação.............................................. 43

4.2.3 Teores de matéria seca das raízes pubadas ......................................... 48

4.2.4 Valores de textura das raízes pubadas................................................ 53

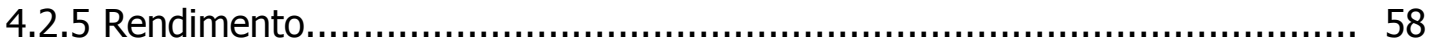

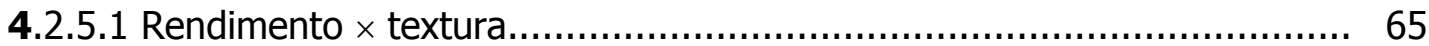

4.3 Propriedades físico-químicas das amostras de farinha de puba..................... 69

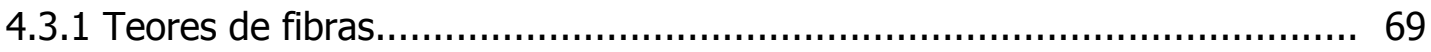

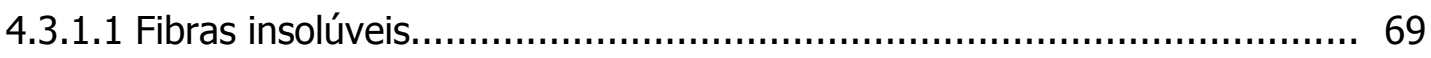

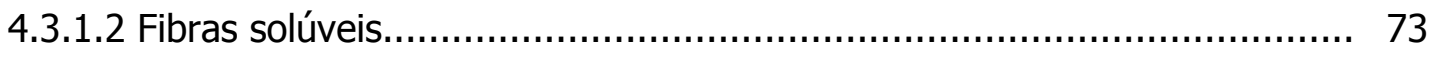




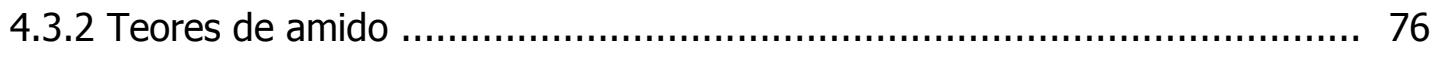

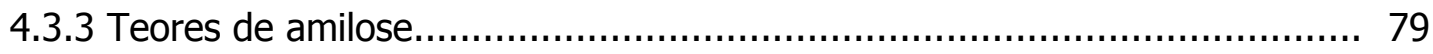

4.3.4 Teores de açúcares solúveis totais............................................... 83

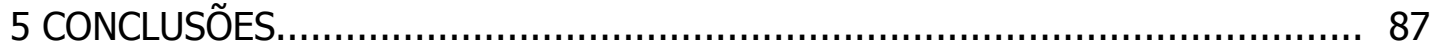

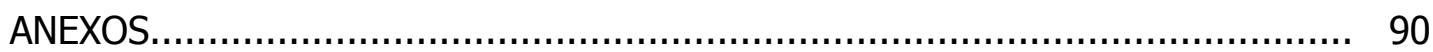

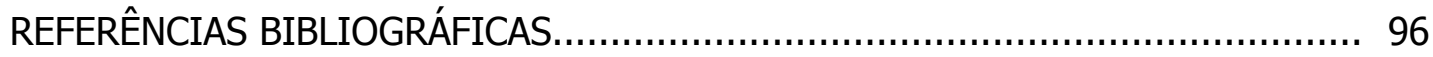




\section{LISTA DE FIGURAS}

Página

1 Esquema de obtenção de puba............................................... 6

2 Raízes de mandioca da cultivar Ouro do Vale................................. 26

3 Fluxograma de produção de puba............................................. 27

4 Aspecto das raízes de mandioca cortadas para a pubagem.................... 28

5 Drenagem do líquido de fermentação......................................... 29

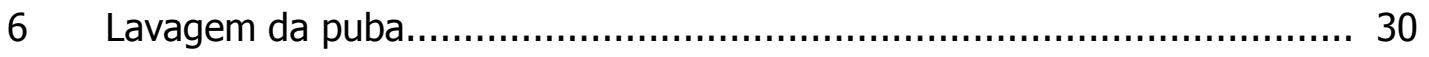

$7 \quad$ Puba após lavagem e prensagem.......................................... 31

8 Aspecto do produto final após a retirada de partes não pubadas.............. 32

9 Aspecto da espuma superficial................................................. 39

10 Aspecto da película na superfície........................................... 40

11 Aspecto do líquido de fermentação - coloração esbranquiçada.................. 41

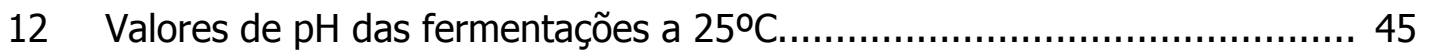

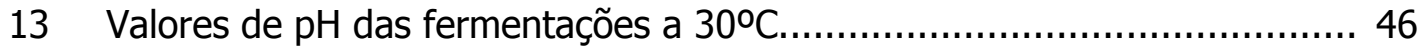

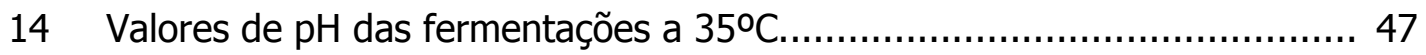

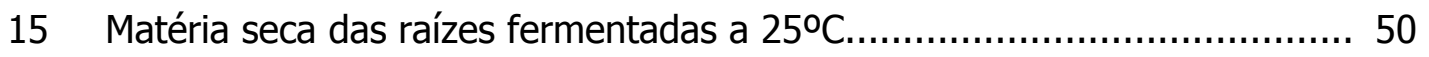

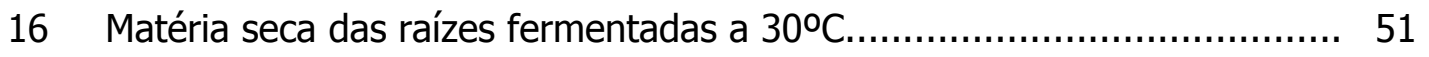

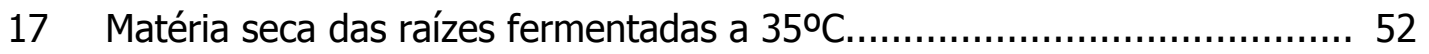

18 Variações da textura das raízes ao longo da fermentação a $25^{\circ} \mathrm{C} . \ldots . . . . . . . . . .54$

19 Variações da textura das raízes ao longo da fermentação a $30^{\circ} \mathrm{C}$................ 55

20 Variações da textura das raízes ao longo da fermentação a $35^{\circ} \mathrm{C}$............... 57

21 Rendimento em função da concentração de enzima da fermentação a

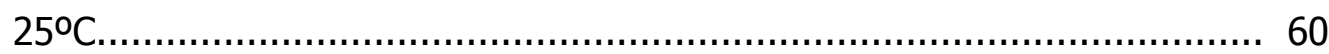

22 Rendimento em função do tempo de fermentação a $25^{\circ} \mathrm{C} . . . . . . . . . . . . . . . . . . .60$ 


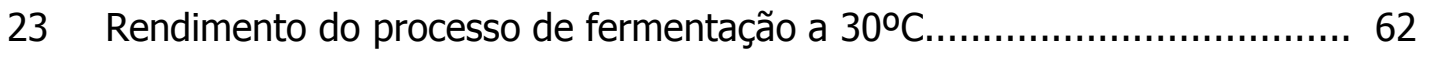

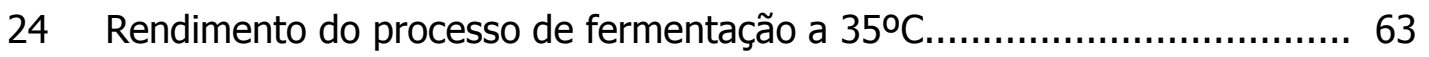

25 Regressão entre rendimento e textura nas temperaturas de $25^{\circ} \mathrm{C}$ (Figura a); $30^{\circ} \mathrm{C}$ (Figura b) e $35^{\circ} \mathrm{C}$ (Figura c) ................................................. 66

26 Regressão entre rendimento e textura nos períodos de 48 horas (Figura a); 72 horas (Figura b) e 96 horas (Figura c) ....................................... 68

27 Fibras insolúveis da matéria-prima e das pubas fermentadas a $25^{\circ} \mathrm{C} . \ldots \ldots . . . .70$

28 Fibras insolúveis da matéria-prima e das pubas fermentadas a $30^{\circ} \mathrm{C}$.......... 71

29 Fibras insolúveis da matéria-prima e das pubas fermentadas a $35^{\circ} \mathrm{C} \ldots \ldots . .72$

30 Fibras solúveis da matéria-prima e das pubas fermentadas a $25^{\circ} \mathrm{C} . . . \ldots \ldots . . . . .73$

31 Fibras solúveis da matéria-prima e das pubas fermentadas a $30^{\circ} \mathrm{C}$............ 74

32 Fibras solúveis da matéria-prima e das pubas fermentadas a $35^{\circ} \mathrm{C}$............ 75

33 Amido da matéria-prima e das pubas fermentadas a $25^{\circ} \mathrm{C}$........................ 77

34 Amido da matéria-prima e das pubas fermentadas a $30^{\circ} \mathrm{C}$....................... 78

35 Amido da matéria-prima e das pubas fermentadas a $35^{\circ} \mathrm{C} \ldots \ldots \ldots \ldots \ldots \ldots \ldots . . . . . . . . . . . .78$

36 Amilose da matéria-prima e das pubas fermentadas a $25^{\circ} \mathrm{C} \ldots \ldots \ldots \ldots \ldots . . . . . . . . . . .80$

37 Amilose da matéria-prima e das pubas fermentadas a $30^{\circ} \mathrm{C}$...................... 80

38 Amilose da matéria-prima e das pubas fermentadas a $35^{\circ} \mathrm{C}$...................... 81

39 Açúcares solúveis totais da matéria-prima e das pubas fermentadas a

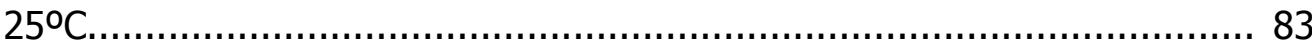

40 Açúcares solúveis totais da matéria-prima e das pubas fermentadas a

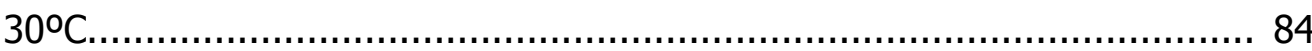

41 Açúcares solúveis totais da matéria-prima e das pubas fermentadas a $35^{\circ} \mathrm{C}$ 


\section{LISTA DE TABELAS}

Página

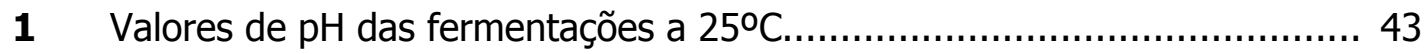

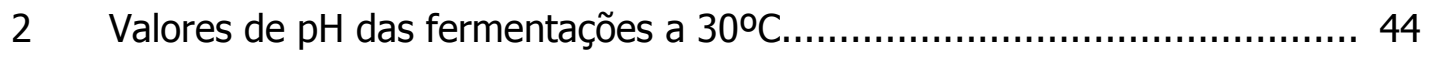

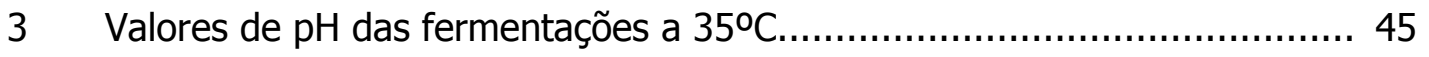

4 Análise estatística dos valores de $\mathrm{pH}$.............................................. 46

5 Matéria seca das raízes durante processo de fermentação a $25^{\circ} \mathrm{C} \ldots \ldots \ldots \ldots . . .48$

6 Matéria seca das raízes durante processo de fermentação a $30^{\circ} \mathrm{C}$.............. 49

7 Matéria seca das raízes durante processo de fermentação a $35^{\circ} \mathrm{C} \ldots \ldots \ldots \ldots . . . . . .50$

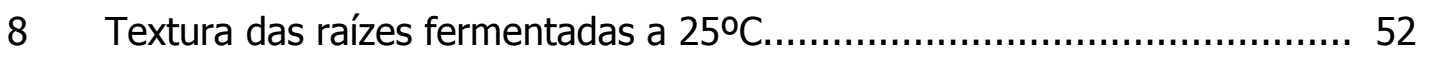

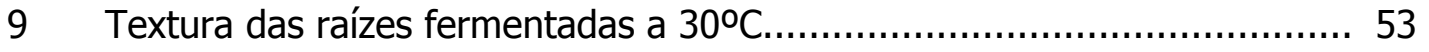

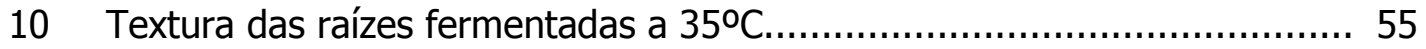

11 Análise estatística dos valores de textura........................................ 56

12 Valores de rendimento do processo de fermentação a $25^{\circ} \mathrm{C} . \ldots \ldots \ldots \ldots \ldots \ldots . . . . . . . . .57$

13 Valores de rendimento do processo de fermentação a $30^{\circ} \mathrm{C} \ldots \ldots \ldots \ldots \ldots \ldots . . . . . . .59$

14 Valores de rendimento do processo de fermentação a $35^{\circ} \mathrm{C} . . . \ldots \ldots \ldots \ldots \ldots . . . . . .61$

15 Análise estatística dos valores de rendimento......................................63 63

16 Análise estatística dos teores de fibras insolúveis.............................. 70

17 Análise estatística dos teores de fibras solúveis.................................. 74

18 Análise estatística dos teores de amido........................................ 77

19 Análise estatística dos teores de amilose....................................... 80

20 Análise estatística dos teores de açúcares solúveis totais.......................... 84 


\section{LISTA DE QUADROS}

Página

1 Características físico-químicas da matéria-prima utilizada no processo....... 37

2 Características de aparência e odor da fermentação no decorrer do

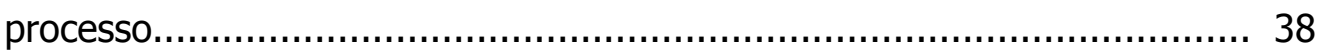




\title{
INFLUÊNCIA DA TEMPERATURA, CONCENTRAÇÃO DE PECTINASE E PERÍODO DE INCUBAÇÃO NA TEXTURA, RENDIMENTO E CARACTERÍSTICAS FÍSICO-QUÍMICAS DA MANDIOCA (Manihot esculenta C.) DURANTE FERMENTAÇÃO
}

\author{
Autora: MARILISA FLAVIA PEREIRA DI-TANNO \\ Orientador: Prof. Dr. TOBIAS JOSÉ BARRETO DE MENEZES
}

\section{RESUMO}

Pubagem é o processo de fermentação natural de raízes de mandioca para produção de puba, um alimento tradicional nas regiões Norte e Nordeste do Brasil. Além da fermentação lática, uma ação combinada da pectina-metil-esterase endógena e enzimas microbianas despolimerizantes causa o amolecimento das raízes, que é importante para sua completa desintegração. No entanto, o reconhecimento do ponto final de fermentação e as condições que propiciam puba de boa qualidade não são completamente esclarecidos. O objetivo do trabalho foi estudar a influência da temperatura de fermentação e da adição de enzima como auxiliar de pubagem na textura das raízes e rendimento de puba, procurando associar estes parâmetros para detectar o ponto final desta etapa do processo. Cerca de $1 \mathrm{Kg}$ de raízes descascadas e 2 litros de água foram colocados em recipientes plásticos. Diferentes concentrações $(0,1$ e $2 \mathrm{~mL}$ ) de pectinase comercial de Aspergillus aculeatus/ $\mathrm{Kg}$ de raiz foram adicionadas em tratamentos separados. Amostras foram incubadas a 25, 30 e $35^{\circ} \mathrm{C}$, por períodos de 48, 72 e 96 horas. Foram efetuadas análises de acompanhamento do processo fermentativo ( $\mathrm{pH}$, textura e rendimento) e da composição da farinha de puba obtida. $\mathrm{O}$ maior rendimento, de $77 \%$ após 72 horas, foi observado no tratamento a $25^{\circ} \mathrm{C}$ com 
$2 \mathrm{~mL}$ de enzima por $\mathrm{Kg}$ de raiz, quando a textura que era de $18,62 \mathrm{lbf} / \mathrm{g}$ na matériaprima passou para 3,92 lbf/g na raiz pubada. Outros rendimentos mais próximos desse valor, 75,7 e $74,7 \%$, foram obtidos respectivamente na fermentação natural a $35^{\circ} \mathrm{C}$ e na amostra tratada com $2 \mathrm{~mL}$ de enzima incubada a $30^{\circ} \mathrm{C} / 48$ horas. Os valores de textura foram de 2,50lbf/g para o primeiro tratamento e 2,89lbf/g para o segundo. A relação entre textura e rendimento foi significativa para a temperatura de $30^{\circ} \mathrm{C}$ e todos os períodos de 72 horas. A associação entre os dados de textura e rendimento permite concluir que quando a textura alcança valores da ordem de $4 \mathrm{lbf} / \mathrm{g}$ os rendimentos de puba são maiores, indicando o final do processo. Os rendimentos mais baixos ocorreram para os valores de textura próximos a 2,30lbf/g de amostra, geralmente obtidos em fermentações mais longas e com maior concentração de enzima. 


\title{
INFLUENCE OF THE TEMPERATURE, CONCENTRATION OF PECTINASE AND INCUBATION TIME ON THE TEXTURE, YIELD AND PHYSICOCHEMICAL PROPERTIES OF CASSAVA (manihot esculenta C.) DURING FERMENTATION
}

\author{
Author: MARILISA FLAVIA PEREIRA DI-TANNO \\ Adviser: Prof. Dr. TOBIAS JOSÉ BARRETO DE MENEZES
}

\section{SUMMARY}

"Retting" is a natural fermentation of cassava roots for the production of puba, a traditional food in the North and Northeast of Brazil. Besides the lactic fermentation, the combined action of the endogenous pectin-methyl-esterase and depolymeryzyng enzymes, causes a softening of the roots which is important for its complete disintegration. However, the recognition of the end point of fermentation and the conditions that lead to good quality puba are not completely understood. The objective of this work was to study the influence of the temperature and enzyme concentration on the yield and texture, aiming at associating these parameters to detect the end point of fermentation. The physicochemical properties of the puba flour were also determined. About $1 \mathrm{Kg}$ of peeled roots and 2 liters of water were placed in plastic containers. One or two milliliters of commercial pectinase from Aspergillus aculeatus were added / $\mathrm{Kg}$ root, in separate treatments. In the control treatment no enzyme was added. Samples were incubated at 25,30 and $35^{\circ} \mathrm{C}$ and portions removed 
after 48, 72 and 96 hours for the determination of $\mathrm{pH}$, texture, yield and dry matter. Fibers, starch, total soluble sugars and amylose were determined in the flour of the dried puba. The highest yield of $77 \%$ was obtained after 72 hours for the treatment at $25^{\circ} \mathrm{C}$ with $2 \mathrm{~mL}$ of enzyme/ $\mathrm{kg}$ of root, when the texture values decreased from $18.62 \mathrm{lbf} / \mathrm{g}$ (raw material) to $3.92 \mathrm{lbf} / \mathrm{g}$ (retted root). A high yield of $75.7 \%$ was also observed in same period, for the natural fermentation at $35^{\circ} \mathrm{C}$, when texture values of $2.50 \mathrm{lbf} / \mathrm{g}$ were reached. The relation between texture and yield was significant for a temperature of $30^{\circ} \mathrm{C}$ and a period of 72 hours. The association between the texture and yield data suggests that when the texture reaches values of the order of $4 \mathrm{lbf} / \mathrm{g}$, the yields are higher, indicating the end of the process. The yields were lower when texture values were close to $2.30 \mathrm{lbf} / \mathrm{g}$, usually achieved for long fermentations and higher enzyme concentrations. 


\section{INTRODUÇÃO}

A puba ou carimã é um produto obtido nas regiões Norte e Nordeste do Brasil, através de processos fermentativos utilizando raízes de mandioca (Manihot esculenta Crantz) inteiras ou em pedaços, diretamente em água estagnada ou dentro de um saco mantido em água corrente. Em ambos os casos, as raízes permanecem de 3 a 7 dias nessas condições, até que amoleçam e comecem a soltar a casca. Em seguida as raízes são esmagadas em peneiras ou côchos de madeira e secas ao sol ou em forno.

O processo de fermentação melhora o sabor, odor e o gosto além de agregar valor e aumentar a vida de prateleira dos produtos da mandioca. Os diversos métodos de fermentação praticado nos diferentes países e a multiplicidade dos produtos elaborados, tornam difícil generalizar as mudanças bioquímicas que acompanham a fermentação da mandioca.

Embora se saiba que a fermentação causa uma série de alterações nas propriedades físico-químicas e funcionais das raízes, tentativas têm raramente sido feitas para consolidar e analisar criticamente as informações disponíveis na literatura.

Flagrantes inconsistentes e visíveis contradições em alguns resultados refletem diferenças e variações no processo artesanal seguido nas preparações dos diversos produtos fermentados de mandioca.

Os processos que utilizam a mandioca como matéria-prima são, em geral, efetuados por meio desuniforme por métodos artesanais e empíricos, sem controle e por período variável de tempo. Ademais, o final do processo fermentativo da puba é reconhecido pelo tato ou visualmente, de tal forma que o reconhecimento tardio ou antecipado pode resultar em menores rendimentos ou características indesejáveis que comprometem a qualidade do produto final. 
Este trabalho teve como objetivo verificar a influência da temperatura, do tempo e da concentração de enzima na textura, no rendimento e nas características físico-químicas da mandioca durante a fermentação. Visando determinar o ponto final do processo, procurou-se relacionar valores de textura com os valores de rendimento de massa de puba obtidos. 


\section{REVISÃO DE LITERATURA}

\subsection{A mandioca como matéria-prima}

A matéria-prima para elaboração da puba, a mandioca, é de origem brasileira e sua produção nacional anual atinge cerca de vinte milhões de toneladas . A região Nordeste é a maior produtora com $34,74 \%$ da produção do país, sendo que o Pará, principal estado produtor brasileiro, contribui com $17,97 \%$ da produção nacional. Já a maior produtividade encontra-se no estado do Paraná com 22,72ton/ha, enquanto os estados do Pará e Bahia, que são os maiores produtores de sua região, apresentam produtividades de 13,82ton/ha e 12,38ton/ha respectivamente (FNP Consultoria \& Comércio, 1999). No recôncavo baiano a mandioca é comercializada crua e transformada em farinha, garantindo grande parte da renda familiar do agricultor.

Em virtude da facilidade de cultivo, resistência a doenças e às condições edafoclimáticas, a mandioca é considerada o pão dos trópicos (Mariath, 1986). Além da puba, muitos outros produtos são obtidos da mandioca (folhas e raízes) como o beiju, a tapioca, a maniçoba, o tucupi, o tacacá, a goma e o arubê, e vários tipos de farinha, como a farinha d'água, a farinha seca ou de mesa, a mista e a do Pará (Maravalhas, 1964; Mendes et al., 1988; Noronha, 1967). Muito embora os produtos fermentados da mandioca sejam largamente empregados na culinária caseira das regiões Norte e Nordeste do Brasil, para confecção de biscoitos, bolos, cuscús, mingaus, entre outros (Albuquerque, 1969), pouco se conhece sobre a qualidade da puba comercializada na Bahia ou em outros locais (Almeida et al., 1993).

A forma de consumo de mandioca varia muito pelos países do mundo (Balagopalan et al., 1988; Lancaster et al., 1982). Na África as técnicas de processamento incluem cozinhar em água fervente, fritar e secar levemente, assar entre outras formas de alimentos elaborados depois da extração do amido 
ou farinha. Outro tipo de processamento consiste em submeter as raízes a fermentação e subsequente conversão em diferentes produtos como gari, fufu (fou-fou), placali, farinha do continente africano, pande yuca, pande-bono, e tape kalella, como ocorre com alguns produtos fermentados de mandioca nas fazendas do Leste da África (Balagopalan et al., 1988; Lancaster et al., 1982).

Até o final da década de 80 , a mandioca era considerada pela população brasileira como um produto para as camadas mais humildes da população, mas nos últimos anos as novas tecnologias estão permitindo que a mandioca se destaque no contexto alimentício como um produto tão importante quanto a soja, o milho, o trigo, a cana-de-açúcar, entre outros (A.B.A.M., 2001).

Como produtora básica de energia, a mandioca supre de nutrientes 500 milhões de pessoas, estando em $4^{\circ}$ lugar depois de arroz, trigo e milho. A planta tem uma produção eficiente mesmo sob condições adversas e irregulares como baixa taxa de precipitação e baixa fertilidade do solo. A alta eficiência em produção de energia resulta em menor emprego de mão-de-obra por calorias colhidas e uma boa flexibilidade no cronograma de gastos com insumos e tratos culturais (Balagopalan et al., 1988).

Dados da Associação de Produtores de Amido e Mandioca (A.B.A.M., 2001) mostram que a fécula de mandioca tem sido exportada principalmente para países Asiáticos. Segundo a A.B.A.M., hoje a produção européia de amido utiliza $19 \%$ do total de milho e 3,6\% de trigo. Este mercado pode ser conquistado pelo amido derivado da mandioca, uma vez que esta mostra elevada produtividade por hectare, necessitando de menor superfície plantada, ao contrário dos cereais produtores de amido.

Com a estabilização econômica e a criação do Mercosul, foram abertas possibilidades para o Brasil na conquista deste mercado, uma vez que nosso país apresenta extenso período de colheita ( 6 a 12 meses) em relação a outros países produtores. Estes dados mostram um mercado importante para exploração de empresas que atuam no setor de fecularia, possibilitando transformar os sub-produtos e os resíduos da extração de amido em produtos nobres, com alto valor econômico. No Brasil a exploração destes sub-produtos pelas empresas é ainda irrisória. Com a globalização o mercado de sub-produtos do amido selecionará as empresas mais 
competitivas, ou seja, aquelas que valorizem melhor esses sub-produtos e resíduos, baixando o custo na produção e aumentando a lucratividade e a competitividade (A.B.A.M., 2001).

As raízes de mandioca contêm elevados teores de amido e quantidades muito menores de proteína, lipídios e outros constituintes bioquímicos (Chadha \& Nair, 1994; Kay, 1987). O amido de mandioca apresenta propriedades importantes, como o elevado teor de amilopectina, que é desejável para alguns fins industriais, devido à viscosidade do seu gel ser relativamente estável, com menor tendência a retrogradação (Okezie \& Kosikowki, 1982).

\subsection{Fermentação da mandioca}

A maceração que ocorre durante o amadurecimento e desfolhamento de vegetais e em processos infecciosos dos tecidos (Call et al., 1985) ocorre também durante a fermentação das raízes de mandioca e é fundamental para o preparo da puba. Na indústria de alimentos, enzimas de maceração têm sido largamente utilizadas em vários processos industriais visando modificar as características reológicas dos produtos, como diminuir a viscosidade e também aumentar o rendimento de extração dos sucos de frutas.

Malta (1958) relata que os índios brasileiros preparavam a puba através da redução das raízes de mandioca a uma polpa, que era deixada amolecer e fermentar, quando então extraíam o líquido tóxico, permanecendo apenas o polvilho, constituído quase que exclusivamente de amido, sem as fibras que existem na farinha. Os processos utilizados pelos indígenas foram absorvidos pelos escravos e posteriormente transferidos para o continente africano.

Basicamente, nas diversas regiões da Bahia, a puba é produzida por dois processos, conforme esquematizados no fluxograma da Figura 1 por Almeida et al. (1993). 


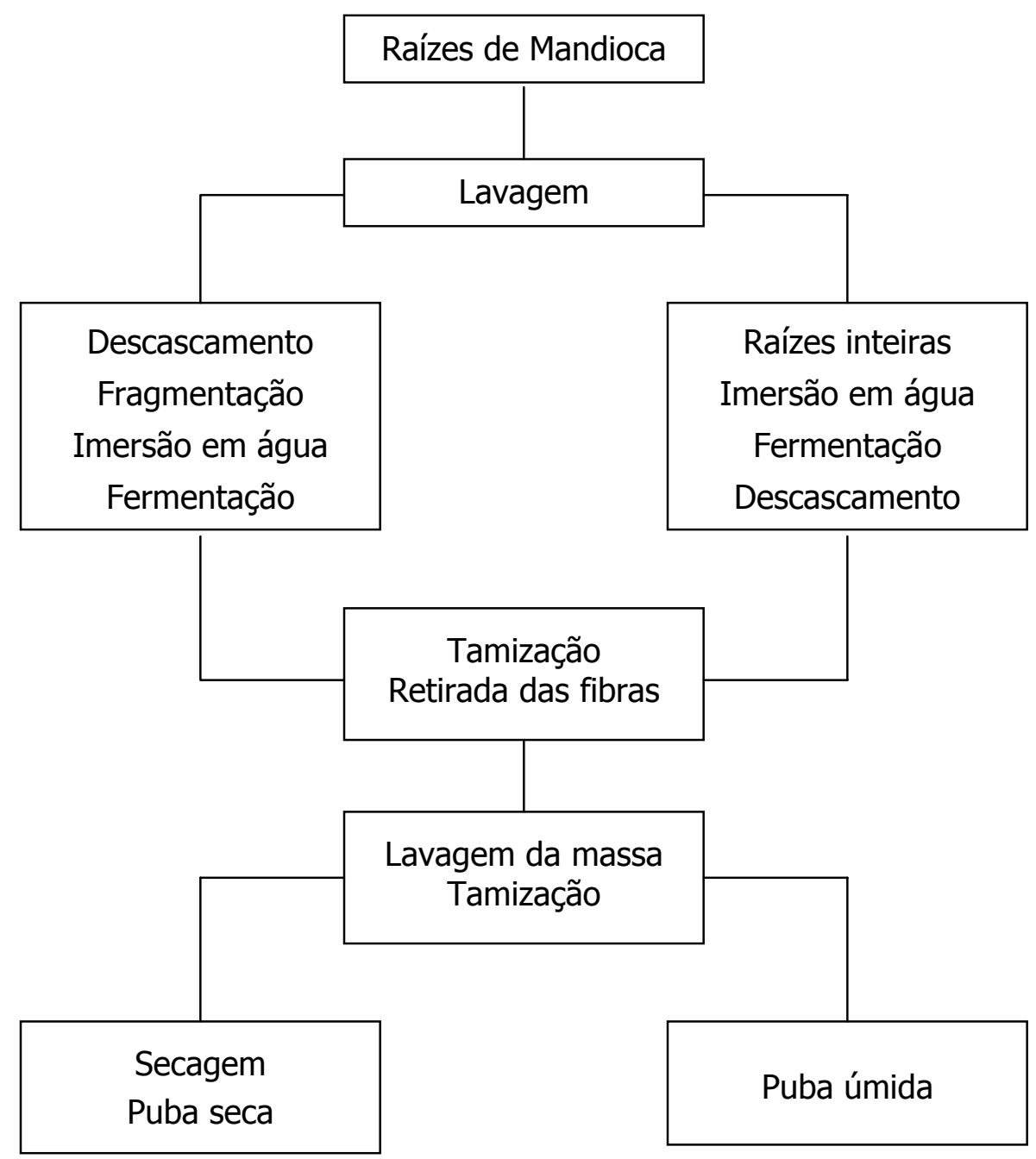

Figura 1 - Esquema de obtenção de puba.

Segundo Oyewole (1992) a fermentação da mandioca pode ser categorizada em dois tipos principais: a fermentação da raiz no estado sólido (no qual a raiz não está embebida em água) e o processo de fermentação submerso (utilizado para obtenção da puba). O período de fermentação depende das condições ambientais, da cultivar e da idade das raízes, da temperatura e $\mathrm{pH}$ da água.

Outros produtos podem ser obtidos pela fermentação da mandioca submersa em água, por um período curto (2-3 dias), como o lafum e o fufu. A pasta obtida da fermentação das raízes pode ser peneirada molhada e cozida em água fervente até formar uma massa dura chamada fufu na Nigéria (Oyewole \& Odunfa, 
1989), ou submetida a outro processo o qual pode incluir peneiramento, secagem ao sol, defumação e moagem para obtenção de farinha. Esta farinha pode ser cozida até obter uma massa dura chamada lafum na Nigéria (Oyewole \& Odunfa, 1988).

Um produto obtido através da fermentação sólida da mandioca é o gari como é conhecido no Oeste da África. Segundo Ayres (1972), Akinrele (1964), Collard \& Levi (1959), este processo de produção consiste em moer as raízes de mandioca e submete-las a fermentação natural (por 3-5 dias), ocorrendo liberação de ácido cianídrico, seja por abaixamento do $\mathrm{pH}$, seja por ação de enzimas endógenas. A massa fermentada é desidratada, peneirada e assada antes do consumo.

A fermentação da mandioca objetiva conferir novas características tecnológicas e sensoriais ao produto, além de reduzir sua toxicidade, através da eliminação parcial do ácido cianídrico presente em elevado teor nas variedades utilizadas para fins comerciais (Cereda, 1973). Todas as plantas de mandioca apresentam um princípio tóxico devido à presença de glicosídeos cianogênicos conhecidos como linamarina e lotaustralina, os quais sob ação de ácidos ou enzimas, sofrem hidrólise e liberam acetona, açúcar e ácido cianídrico (HCN). O HCN é extremamente tóxico pois inibe a atividade das enzimas da cadeia respiratória dos seres vivos (Câmara et al., 1982).

A fermentação tem sido tradicionalmente praticada em muitos países da África e América Latina como meio de aperfeiçoamento das qualidades de textura das farinhas e sabor dos produtos (Oyenuga, 1968; Oyewole \& Odunfa, 1989).

\subsection{Condições microbiológicas da fermentação de mandioca}

$\mathrm{Na}$ fermentação da mandioca está presente uma larga variedade de microrganismos (Akinrele, 1964; Balagopalan et al., 1988) como bactérias, leveduras e bolores, podendo ocorrer (Akinrele, 1964; Cereda et al., 1985) em estado sólido ou submerso em água por períodos diferentes (Bokanga \& Steinkraus, 1988; George et al., 1992) como da noite para o dia, por semanas ou até meses, obtendo-se assim diversos produtos alimentícios diferentes e bebidas alcoólicas (Moorthy \& George, 1998).

A maioria dos processos fermentativos que utilizam a mandioca, são efetuados por meio de métodos artesanais, empíricos, sem controle e por variáveis 
períodos, através dos quais ocorrem alterações significativas da flora microbiana (Adegoke \& Babaloa, 1988; Almeida et al., 1987; Cereda, 1973; Okafor et al.,1984; Oyewole \& Odunfa, 1988;).

Almeida et al. (1987) afirmam que os microrganismos tipo enterobactérias, corinebactérias, lactobacilos, leuconostocos, enterococos e leveduras formadoras de película estão envolvidas na produção da puba. Na oportunidade observaram que existiam alterações na microbiota durante a produção da puba, sendo que nas primeiras 24 horas predominaram Erwinia, Klebisiella, Corinebacterium e Streptococcus. Após esse período a contagem dos três primeiros gêneros citados decresceu gradualmente até desaparecer no terceiro dia de fermentação. As bactérias láticas dos gêneros Streptococcus, Lactobacillus e Leuconostoc foram aumentando gradualmente até predominarem no final da fermentação.

Almeida (1993) confirmando os resultados anteriores, ressaltou o fenômeno da sucessão bacteriana de modo que a participação das enterobactérias e corinebactérias se reduz durante o processo fermentativo, dando lugar ao desenvolvimento da flora lática e esporulada que ao final da fermentação, atinge cerca de $80 \%$ da microbiota total.

Okafor et al. (1984) efetuando um estudo sobre a microbiologia da maceração da mandioca para produção de fufu, isolaram bactérias dos gêneros Bacillus, Lactobacillus, Klebsiella, Leuconostoc e Corynebacterium, bem como a levedura do gênero Candida. Por sua vez, Adegoke \& Babaloa (1988) verificaram que os microrganismos predominantes durante a fermentação do fufu foram Streptococcus fecalis, coliformes, Bacillus subtilis, B. polymyxa, Lactobacillus fermentum, L. brevis e Saccharomyces cerevisae.

Para outros pesquisadores, os microrganismos mais freqüentes envolvidos na fermentação da mandioca também foram os bacillus, corinebactérias, coliformes, bactérias lácticas, leveduras além de clostrídios (Adegoke \& Babaloa, 1988; Almeida et al., 1987; Cereda, 1973; Oyewole \& Odunfa, 1988; Oyewole \& Odunfa, 1990; Okafor et al., 1984).

Com exceção do Clostridium e Pediococcus, os organismos mencionados anteriormente também já foram encontrados em produtos fermentados da mandioca, 
cujo sistema de produção é similar ao da puba ou carimã, como o fufu (Adegoke \& Babaloa, 1988; Okafor et al., 1984).

Durante a obtenção da puba há que se considerar o aspecto higiênico sanitário, pois de acordo com Gravatá (1940), no sistema rotineiro de fermentação, as raízes são imersas em águas não tratadas e em seguida são submetidas a processos manuais até a sua comercialização. Muito embora a puba apresente $\mathrm{pH}$ em torno ou abaixo de 5,0 é conveniente lembrar que no início da fermentação há participação de enterobactérias, conforme cita Almeida (1993). Alimentos submetidos a esse tipo de processamento devem ser analisados microbiologicamente para garantir sua qualidade conforme menciona APHA (1976). As oportunidades de contaminação, segundo Frazier (1978), poderão introduzir microrganismos do solo, água, utensílios, superfícies e mãos dos manipuladores. As precárias condições de processamento, conservação e comercialização podem se refletir nas propriedades tecnológicas da puba, na sua vida útil e eventuais riscos aos consumidores.

\subsection{Bioquímica da fermentação de mandioca}

$\mathrm{Na}$ fermentação da mandioca estão envolvidas enzimas amilolíticas, pectinolíticas, a degradação do glicosídeo cianogênico e o metabolismo de carboidratos em compostos como ácidos, álcoois, aldeídos, ésteres e acetonas.

Quanto aos aspectos bioquímicos para produção do fufu, Okafor et al. (1984), verificaram que apenas microrganismos dos gêneros Bacillus e Corynebacterium $s p$. eram capazes de amolecer a mandioca e hidrolisar a fécula. Segundo os autores, as bactérias produtoras do ácido lático abaixam o pH do meio a valores inferiores a 4,0, conferindo aroma típico do fufu mas não promovem o amolecimento. Por outro lado, somente os Corinobacterium sp. apresentavam enzimas pectinolíticas, sugerindo que os Bacillus $s p$. causam amolecimento da mandioca por desintegração de outros componentes celulares.

Ohochuku \& Ballantine (1983) avaliando os componentes responsáveis pelo odor do fufu, encontraram ácido acético, ácido propiônico e ácido butírico, sendo que o último era o responsável pelo odor desagradável. Maravalhas (1964) acredita que o sabor e odor da farinha d'água são formados durante o amolecimento, indicando 
fermentação butírica, provavelmente através de Clostridium $s p$, devido ao acentuado odor butírico exalado.

Collard \& Levi (1959) acompanhando a fermentação do gari, verificaram que o processo ocorre em dois estágios: na primeira fase o Corinebacterium manihot degrada o amido com produção de ácidos orgânicos (inclusive ácido lático) durante as primeiras 24 horas, criando condições ( $\mathrm{pH}$ e nutrientes oxidáveis) favoráveis para o desenvolvimento do fungo Geotricum candidum, assim como para a decomposição do glicosídio cianogênico. Esse último organismo inicia a segunda fase, tornado-se paulatinamente predominante até o fim do processo fermentativo, produzindo aldeídos e ésteres que conferem o aroma e o sabor característicos do gari. Segundo Tinay et al. (1984), a perda de ácido cianídrico é significativa no primeiro dia de fermentação e é maior em raízes moídas que inteiras.

Akinrele (1964) encontrou elevada proporção de ácido lático na polpa de mandioca fermentada durante o primeiro estágio da produção do gari, o que também já havia sido relatado por Collard \& Levi (1959), embora estes autores não tenham isolado bactérias láticas. Abe \& Lindsay (1978) afirmaram que os microrganismos responsáveis pela produção de ácidos orgânicos não são do gênero Corynebacterium, em função dos valores de pH e acidez encontrados, como foi relatado por Akinrele (1964), visto que a maioria das espécies de Corinebacterium oxida a glicose completamente a $\mathrm{CO}_{2}$ e água.

\subsection{Aspectos físico-químicos da fermentação}

Durante a fermentação da puba, Almeida et al. (1987), verificaram que o processo fermentativo pode ser acelerado empregando-se em vez das raízes inteiras, pequenos fragmentos colocados em água a temperaturas próximas a $30^{\circ} \mathrm{C}$. Trabalhos realizados para obtenção de fufu por Okafor et al. (1984) sugerem que o tamanho da raiz afeta a velocidade de maceração, porém Ampe et al. (1994), trabalhando com raízes inteiras concluíram em seus experimentos que esse fator não tem efeito significativo na velocidade deste processo. Assim como outras variáveis como o tempo de estocagem, a retirada da película externa e a variedade da mandioca parecem ter 
pouca ou nenhuma influência na velocidade de maceração para produção de fufu. Porém afetaram a qualidade organoléptica do produto.

\subsection{1 pH}

A diminuição do pH e aumento da acidez titulável são efeitos comumente observados e relatados em fermentações de mandioca para obtenção dos mais variados produtos (Almeida, 1992; Braumam et al., 1995; Menezes et al., 1998; Olivieri et al., 1999).

Oyewole \& Odunfa (1988) estudando a fermentação de lafum relatam que a acidez titulável do líquido da fermentação e das raízes aumentou rapidamente, reduzindo o pH a níveis inferiores a 4,0. A temperatura oscilou entre 30 e $32^{\circ} \mathrm{C}$.

George et al. (1995) mensuraram os valores de pH do líquido durante a fermentação de 4 cultivares de mandioca. Estes variaram entre 5,67 a 6,05 no início do processo. Após 24 horas de fermentação os valores reduziram, variando entre 4,3 e 4,7. Após 72 horas de fermentação variou de 4,1 a 4,3 indicando um apreciável enriquecimento de ácidos orgânicos devido a fermentação. Akinrele (1964) também verificou que os ácidos orgânicos se formaram na fermentação da mandioca. Ácidos orgânicos produzidos durante a maceração da mandioca também foram relatados por Ampe et al. (1994).

Segundo Brauman et al. (1995) e Menezes et al. (1998) o abaixamento do pH ocorre logo no início da fermentação. A tensão de oxigênio dissolvido no líquido também diminui rapidamente (após 10 horas de fermentação) e se estabiliza após o segundo dia de fermentação ao redor de 4,5 e 0,05mg/L respectivamente (Braumam, et al. 1995).

$\mathrm{O} \mathrm{pH}$ das raízes fermentadas moídas é maior do que o $\mathrm{pH}$ do líquido de fermentação segundo Brauman et al. (1995). Já Moorthy \& George (1998) relataram que não existe muita diferença entre $\mathrm{o}$ pH do líquido de fermentação e pedaços de raízes fermentadas. 


\subsubsection{Matéria seca}

A maioria das fermentações envolvem procedimentos de embebição das raízes em água por longos períodos e alterações na matéria seca podem ser observadas (Moorthy \& George, 1998).

Um pequeno aumento no conteúdo de matéria seca foi observado durante fermentações para obtenção de gari e lafum (Ketiku et al., 1978). As alterações de matéria seca para o gari foram de $37,6 \%$ no início da trituração para $40,7 \%$ após 48 horas de fermentação, sendo estes valores considerados estatisticamente iguais $(p>0,01)$. Os valores de matéria seca só foram estatisticamente diferentes $(48,7 \%)$ após o gari permanecer 24 horas pressionado. Já para o lafum os valores de matéria seca foram de 39,3\% no início da trituração e 39,9\% após 5 dias de embebição. Estes valores apresentaram-se elevados após 48 horas de secagem $(86,5 \%)$.

Menezes et al. (1999), observaram uma diminuição dos teores de matéria seca da puba em relação a matéria-prima, tanto nas pubas obtidas da fermentação natural quanto as tratadas com enzima.

Reduções nos valores de matéria seca também foram observadas por George et al. (1995) em 4 variedades com adição inicial de inóculo misto, encontrando redução máxima dentro das primeiras 24 e 48 horas de fermentação em todos os casos. A perda em matéria seca pode ser, em parte, devido a redução do conteúdo de açúcares e amido e ao amaciamento das raízes que conduz a um aumento na absorção de água, contribuindo para a redução do peso seco.

Oyewole \& Odunfa (1988) relataram que o teor de umidade aumentou de $70,34 \%$ dentro das 36 horas iniciais e que gradualmente diminuiu para cerca de $60 \%$ durante o restante do período de fermentação para obtenção do lafum. A perda durante o período final foi atribuída a osmose.

De acordo com Almeida (1992) os teores de 7-9\% de umidade no produto final são considerados adequados para sua conservação. Entretanto os valores encontrados na literatura, como adequados, situem-se em torno de $12-14 \%$. 


\subsubsection{Amaciamento das raízes}

Durante o amaciamento das raízes para produção de gari, fufu e lafum, a textura das raízes passa por uma visível alteração, tornando-se macias. Geralmente, o amaciamento das raízes é observado durante o segundo dia e continua até o quarto dia na fermentação tradicional (Oyewole, 1990).

O amolecimento dos tecidos durante a fermentação pode ser atribuído ao aumento da atividade de enzimas pectinolíticas e celulolíticas. Estas são produzidas por microrganismos e ajudam nas operações de redução de tamanho como esmagamento e trituração. Acredita-se que o processo de degradação envolve principalmente $o$ arranjo da estrutura que une as moléculas de amido (Okechukwu et al., 1984).

Olivieri et. al. (1999) acompanharam o desenvolvimento da textura de duas cultivares ao longo do processo fermentativo para produção de puba. Os resultados demonstraram que até 24 horas de fermentação a textura não apresentou grandes alterações, mantendo-se constante ou tendendo a pequena elevação. Uma acentuada queda nos valores de textura ocorre entre 24 e 48 horas de fermentação. Os valores de textura tenderam a pequenas reduções até completar 72 horas de processamento. O comportamento dos valores de textura ao longo da fermentação apresentou-se semelhante para todas as cultivares e tratamentos.

Também Brauman et al. (1995) a partir do segundo dia de fermentação constataram uma alteração importante nas células vegetais que se manifesta por um amolecimento da raiz de mandioca. A característica de amolecimento foi avaliada pelo índice de penetrometria, parâmetro que permite quantificar este amolecimento ao longo da fermentação. As paredes celulares são progressivamente quebradas e os grãos de amido são lixiviados para a água de maceração, dando ao meio uma cor branca característica. Apesar da alteração das células vegetais, a perda em matéria seca durante o processo foi pouca, menos de $20 \%$.

Ampe et al. (1994) usaram o amaciamento dos tecidos como um índice de determinação de velocidade de maceração. Neste estudo, o amaciamento foi monitorado pelo penetrômetro e os valores foram usados para determinar o tempo da fermentação. Neste trabalho, os autores avaliaram vários fatores a fim de definir as 
condições ótimas para o processo. $O$ índice de penetrometria foi utilizado como indicador do amolecimento da raiz durante a maceração de acordo com o que foi preconizado por Brauman et al. (1991) os quais determinaram que $15 \mathrm{~mm} / \mathrm{s}$ corresponderia ao fim da maceração.

Segundo Oyewole (1990) a padronização de valores ideais de índice de penetrometria e sua correlação com o amaciamento das raízes, constituem uma eficiente forma de monitorar a fermentação. Entretanto, poucos experimentos foram feitos até hoje neste sentido.

A velocidade de amolecimento das raízes para produção do fufu foi realçada com a redução do tamanho dos pedaços de raiz a temperatura entre 30 a $40^{\circ} \mathrm{C}$ com duração de 48 horas, facilitando a maceração (Okafor et al., 1984).

O amolecimento das raízes de mandioca durante a fermentação usando um inóculo de cultura mista foi estudado em detalhes por Nanda \& George (1996) para produção de farinha amilácea. Neste trabalho, o comportamento da força de compressão (textura) de duas variedades $(\mathrm{H}-1687$ e H-2304) sobre uma carga de compressão axial foi avaliado. Raízes frescas foram submetidas a fermentação por 18 , 24 ou 48 horas. A força de compressão nas raízes diminuiu conforme o tempo de fermentação de $6,827 \pm 0,89 \mathrm{Kg} / \mathrm{cm}^{2}$ no tempo zero, para 0,583 $\pm 0,24 \mathrm{Kg} / \mathrm{cm}^{2}$ após 48 horas de fermentação. Os valores de deformação e ruptura aumentaram com a duração da fermentação de $10,92 \pm 2,11 \%$ no tempo zero para $13,12 \% \pm 1,41 \%$ após 24 horas de fermentação, seguido de um decréscimo para 7,53 $\pm 3,16 \%$ após 48 horas de fermentação. Este comportamento se repetiu para as duas variedades testadas, mas diferenças das forças de compressão iniciais foram observadas entre as variedades. A redução da força de compressão inicial foi de $8,54 \%$ para a $\mathrm{H}-2304$ e $20,06 \%$ para a $\mathrm{H}-1687$ depois de 48 horas de fermentação.

Importante salientar que Ayernor (1985), considerou que o estabelecimento de metodologia para a determinação de um índice de textura é importante critério objetivo para se detectar o final da fermentação, embora tenha sido relatado que a taxa de desintegração dos tecidos não segue nenhum padrão definido com respeito ao índice de textura. 


\subsubsection{Rendimento}

A quantidade de puba produzida em relação à quantidade de matériaprima inicial exprime o rendimento do processo e tem grande importância do ponto de vista técnico-econômico.

O rendimento do processo para produção de puba foi avaliado por Olivieri et al. (1999). Observou-se que o rendimento obtido para as pubas elaboradas sem adição de enzima $(68,3 \%)$ para a cultivar Ouro do Vale apresentou-se menor que o rendimento obtido do tratamento adicionado de enzima $(71,6 \%)$.

Menezes et al. (1999) observaram um rendimento, em valores médios de $14,7 \%$ quando a puba foi obtida com adição de celulase e $42,2 \%$, quando adicionado de pectinase. O maior valor, no entanto, foi obtido durante a fermentação natural $(54,7 \%)$. Nestes experimentos, os autores relataram grande variabilidade entre as repetições, atribuída, provavelmente, ao amolecimento desuniforme das raízes durante o processo fermentativo, não sendo possível relacionar o rendimento com o teor de enzima empregado. $\mathrm{O}$ baixo rendimento obtido na puba processada com adição de celulase foi atribuído pelos autores à pronta desintegração dos tecido pela enzima com conseqüente perda do amido. Entretanto, a puba produzida por fermentação natural também apresentou valores inferiores aos relatados na literatura. Segundo os autores, lavagens prolongadas nas amostras poderiam ter causado intensa lixiviação do amido.

Ayernor (1985) relata rendimentos entre 65 e $72 \%$ em experimentos de fermentação natural, dependendo da variedade. Segundo este autor, quanto menor a relação fibra/casca maior o rendimento do produto final. 


\subsubsection{Carboidratos}

\subsubsection{Fibras}

Almeida (1992) verificando a composição centesimal de 25 amostras de puba úmida comercializadas no recôncavo baiano observou valores mínimos de fibra de $1,55 \%$, médios de $2,16 \%$ e máximos de $4,60 \%$.

Estudos indicam claramente que os níveis de fibra mudam dependendo das condições da fermentação (Moorthy \& George, 1998).

Olivieri et al. (1999) estudaram a fermentação de duas variedades de mandioca para obtenção de puba, com e sem enzima, por 72 horas. Os teores de fibra total da matéria-prima tenderam a decrescer em ambas as variedades em fermentação, possivelmente devido à presença de enzimas pectinolíticas formadas ou acrescentadas ao processo.

Menezes et al. (1999) durante experimentos para produção de puba com e sem adição de enzimas (pectinase e celulase) observaram que os teores de fibra solúvel $(1,60$ a $1,05 \mathrm{~g} / 100 \mathrm{~g})$ tenderam a diminuir em relação à matéria-prima $(2,31 \mathrm{~g} / 100 \mathrm{~g})$. Entretanto, os valores de fibra insolúvel tenderam a um ligeiro aumento ou estabilização.

Uma pequena redução nos teores de fibras dietéticas foi observada na maioria dos produtos fermentados de mandioca, exceto o Kpokpo gari, em que um aumento triplo foi relatado (Longe, 1980).

Uma comparação dos teores de fibra no fufu e akpu revelaram que as fibras dietéticas foram menores na fermentação tradicional envolvendo leveduras quando comparadas com fermentação bacteriana. Isto porque as leveduras são tolerantes a baixos valores de $\mathrm{pH}$ e continuam degradando os polissacarídeos ao longo do período resultando numa redução dos níveis de fibra dietética. Os resultados indicaram que para se realizar um aumento nos níveis de fibra dietéticas no produto final, a fermentação bacteriana deve ser superior a fermentação por leveduras (Okolie et al., 1992).

Os teores de fibra diminuíram de 1,98\% em amostras obtidas de fermentações sem inóculo para 1,58\% com o uso de um inóculo natural. A perda de 
$22 \%$ ocorreu entre 12 e 48 horas (Bokanga et al., 1990). Contudo Numfor et al. (1995) não encontraram alteração significativa no conteúdo de fibras durante a fermentação.

George et al. (1995) estudando as mudanças bioquímicas durante a fermentação da mandioca por 72 horas usando inóculo de cultura mista revelaram que a farinha amilácea (amido) produzida tem maiores teores de fibra bruta que as farinhas obtidas de raízes não fermentadas. Os resultados mostram que os teores de fibra nas raízes fermentadas aumentaram com o tempo de fermentação, sendo o efeito uniforme entre as variedades analisadas. A fibra bruta contida na farinha amilácea obtida de raízes não fermentadas variou de 1,06 a 2,6g/100g. No entanto o aumento foi maior na farinha amilácea obtida de raízes fermentadas variando de 6,8 a 11,64g/100g.

O aumento do conteúdo de fibras segundo George et al. (1995) foi devido a ação de enzimas pectinolíticas e celulolíticas produzidas pela cultura mista, que ajudam a solubilizar as membranas da parede celular e liberar os grânulos de amido retidos. Neste caso o amido, da farinha amilácea, extraído está acompanhado de material fibroso resultante da ação das enzimas.

Numfor et al. (1995) avaliaram as alterações nos teores de fibra bruta ocorridas em amidos de mandioca (polvilho) comercial, fermentado naturalmente e fermentado com uso de inóculo, em relação ao originalmente presente nas raízes. Em todas as amostras os teores de fibra bruta diminuíram em relação ao teor original $(0,23 \% \pm 0,06) .0$ amido obtido da fermentação com uso de inóculo apresentou os menores valores $(0,11 \% \pm 0,06)$ quando comparado com o fermentado naturalmente $(0,13 \% \pm 0,12)$ e com o amido comercial $(0,15 \% \pm 0,04)$. No mesmo trabalho os autores avaliaram os teores de fibra bruta em duas farinhas de mandioca, obtidas por fermentação natural e adicionada de inóculo. Em ambas farinhas os valores diminuíram em relação ao conteúdo original $(1,13 \% \pm 0,08)$ presente na raiz. Na farinha obtida da fermentação natural os valores de fibra bruta $(1,03 \% \pm 0,12)$ foram inferiores aos encontrados na farinha fermentada com inóculo $(1,11 \% \pm 0,05)$. 


\subsubsection{Amido}

Almeida (1992) analisando o conteúdo de amido de 25 amostras de puba úmida comercializada no recôncavo baiano determinou valores mínimos de 77,58\%, médios de $86,62 \%$ e máximos de $95,78 \%$ amido, expressos em base seca.

Menezes et al. (1999) constataram que as amostras fermentadas de puba, principalmente as tratadas com enzimas, tiveram redução da concentração do amido em relação a matéria-prima. Os valores variaram de $89,1 \%$ na matéria-prima, para $86,06 \%$ na fermentação natural, e o menor valor de $74,7 \%$ no tratamento com $1,5 \mathrm{~g}$ de celulase/ $\mathrm{Kg}$ de raiz.

De acordo com Ketiku et al. (1978) alterações não significativas no conteúdo de amido ocorreram durante a fermentação de gari e lafum, enquanto Longe (1980), relatou uma redução significativa de $28,82 \%$ no conteúdo de amido durante uma fermentação para produção de KpoKo gari e uma redução menor, de apenas $15,18 \%$ e $17,89 \%$ na produção de fufu e pukuru respectivamente. A redução no conteúdo de amido foi atribuída a conversão de açúcares pelos microrganismos durante a fermentação (Meuser et al., 1980).

Oyewole \& Odunfa (1989) obtiveram resultados semelhantes aos anteriores quanto ao comportamento dos teores de amido durante a fermentação da mandioca para produção de fufu. Os teores de amido diminuíram gradualmente de $81 \%$ no tempo zero para $47 \%$ após 96 horas de fermentação.

George et al. (1995) mostraram que o inóculo de cultura mista realça a extratividade de amido das raízes. Isso ocorre pela ação de enzimas pectinolíticas e celulolíticas, produzidas ou adicionadas, os quais quebram a membrana da parede celular e liberam o grânulo de amido.

Neste trabalho, George et al. (1995) estudaram as transformações bioquímicas das raízes de mandioca, em 4 variedades diferentes, durante a fermentação com a adição de inóculo de cultura mista. A diminuição do conteúdo de amido não foi significativo no estágio inicial do processo, pois como existe um conteúdo suficiente de açúcares para os microrganismos utilizarem, o amido não é atacado por estes. No entanto, em estágios posteriores da fermentação, quando existe um decréscimo nos teores de açúcares, os microrganismos começam a quebrar o amido para disponibilizar açúcar. Neste trabalho os autores relataram uma redução no 
conteúdo de amido de 33,13g/100g (base fresca) no tempo zero de fermentação para $30,70 \mathrm{~g} / 100 \mathrm{~g}$ (base fresca) após 72 horas de fermentação.

Durante a fermentação a diminuição dos teores de amido foi acompanhada pelo decréscimo do teor matéria seca contidos nas raízes. (George et al., 1991).

Olivieri et al. (1999) caracterizaram farinhas de puba obtidas em condições de fermentação natural e com enzimas a $28^{\circ} \mathrm{C}$ por 72 horas de fermentação. O teor de amido das pubas obtidas com adição de enzima (82,98\%) apresentou-se maior que o originalmente presente nas raízes $(73,12 \%)$. Já os teores de amido das pubas obtidas sem adição de enzimas (72,90\%) diminuíram em relação aos teores originais. Segundo os autores, a presença de enzimas proporcionou maior retenção de amido no produto final.

\subsubsection{Amilose}

Os processos fermentativos, de acordo com Phan \& Mercier (1984) ocasionam uma diminuição no conteúdo de amilose. Os ácidos orgânicos produzidos durante a fermentação formam complexos com a fração solúvel da amilose, levando com isso uma redução aparente no conteúdo de amilose solúvel. Esta formação de complexo conduz ao aumento da temperatura de gelatinização e acentua a viscosidade do fufu (Phan \& Mercier, 1984). Contudo, tal redução de amilose não foi relatada em outros trabalhos (Camargo et al., 1988; Martinez \& Quiroga, 1988).

Numfor et al. (1995) avaliaram as alterações nos teores de amilose ocorridas em amidos de mandioca comercial, amidos e farinhas obtidas em condições de fermentação natural ou utilizando inóculo de cultura mista em relação ao originalmente presente nas raízes. Observaram aumento no conteúdo de amilose tanto nos amidos extraídos quanto nas farinhas obtidas pela fermentação natural ou utilizando inóculo de cultura mista em relação a raiz. Este resultado não é usual e foi explicado pela provável formação de um material semelhante a amilose, como resultante da ação das enzimas e hidrólises ácidas da amilopectina nas regiões amorfas do grânulo de amido, durante a fermentação. 
Os resultados encontrados por Moorthy et al. (1993) em uma fermentação usando inóculo de cultura mista, indicaram aparente redução nos conteúdos de amilose total e solúvel, devido a aparente redução do conteúdo de amido na extração da farinha amilácea.

Menezes et al., (1999) observaram um pequeno aumento nos teores de amilose (12,34\%) em amostras de pubas tratadas com 3,0g de celulose por $\mathrm{Kg}$ de raiz, em relação ao presente na matéria-prima $(11,64 \%)$ e ao tratamento testemunha $(11,58 \%)$. Os autores atribuíram aos comportamentos de aumento a formação de material semelhante a amilose proveniente da hidrólise do amido; e de redução a formação de complexos dos ácidos orgânicos com a fração solúvel da amilose.

\subsubsection{Açúcares solúveis totais}

Ketiku (1978) e Oyenuga (1968) relataram que o amido e açúcares constituem cerca de $84 \%$ e $4,5 \%$ do total de carboidratos na base seca de raízes não fermentadas, respectivamente.

As raízes de mandioca contêm elevadas quantidades de carboidratos solúveis em água, variando de 3 a $10 \mathrm{~g} / 100 \mathrm{~g}$ em diferentes variedades (Padmaja \& Balogopalan, 1991). Estes valores de carboidratos são suficientes para suprir a assimilação microbiana inicial, necessária para sua proliferação, não havendo necessidade de degradar o amido em açúcar. No entanto, quando ocorre uma depreciação suficiente do conteúdo de açúcar, os microrganismos podem começar a utilizar o amido como fonte de energia o que pode acarretar a sua diminuição nos estágios seguintes da fermentação (George et al., 1991).

Olivieri et al. (1999) analisaram os teores de carboidratos solúveis totais em farinhas de puba obtidas em condições de fermentação natural e com enzimas, a $28^{\circ} \mathrm{C}$ por 72 horas. Os valores tenderam a diminuir no final do processo em relação aos teores encontrados na matéria-prima $(2,55 \mathrm{~g} / 100 \mathrm{~g})$ em ambos tratamentos e variedades testadas, sendo que os valores obtidos da puba adicionada de enzimas $(1,95 \mathrm{~g} / 100 \mathrm{~g})$ apresentou-se pouco superior ao tratamento sem enzima $(1,90 \mathrm{~g} / 100 \mathrm{~g})$. 
Reduções nos teores de açúcares solúveis totais após 48 horas de fermentação também foram relatadas por Longe (1980) e Meuser (1978) em produtos fermentados de mandioca.

Numfor et al. (1995) observaram uma diminuição no conteúdo de açúcares totais tanto nos amidos quanto nas farinhas de mandioca obtidas em condições de fermentação natural ou utilizando inóculo de cultura mista quando comparado aos valores encontrados originalmente nas raízes. Este comportamento coincide com estudos iniciais de Ezeala (1984) e Ketiku et al. (1978).

Estudando as transformações bioquímicas das raízes de mandioca em 4 variedades diferentes, durante a fermentação com a adição de inóculo de cultura mista, George et al. (1995) verificaram que as variações dos teores de açúcar são semelhantes aos descritos anteriormente com valores elevados no estágio inicial do processo $(1,21 \mathrm{~g} / 100 \mathrm{~g}$ no tempo 0$)$ e um decréscimo nos estágios posteriores da fermentação $(0,55 \mathrm{~g} / 100 \mathrm{~g}$ após 48 horas e apenas traços após 72 horas). Esta redução nos teores de açúcares foi observada para as 4 variedades estudadas, indicando uma utilização predominante de açúcares pelos microrganismos devido sua fácil assimilação.

Oyewole \& Odunfa (1989) estudaram os efeitos da fermentação da mandioca nos teores de carboidratos para a produção de fufu. Neste experimento, a fermentação foi acompanhada até 96 horas à temperatura de $30^{\circ} \mathrm{C} \pm 2{ }^{\circ} \mathrm{C}$. Os níveis de açúcares solúveis totais foram medidos a cada 12 horas sendo que estes valores foram sempre maiores em relação a matéria-prima (4 \pm 0,1g/100g). Entre 36 e 48 horas de fermentação os valores de açúcares solúveis se estabilizaram em $11 \pm 0,1 \mathrm{~g} / 100 \mathrm{~g}$. Os valores diminuíram para $9 \pm 0,7 \mathrm{~g} / 100 \mathrm{~g}$ após 60 horas de fermentação e mantiveram-se estáveis até o final do processo com $8 \pm 0,4 \mathrm{~g} / 100 \mathrm{~g}$ após 96 horas de fermentação. Segundo o autor, o decréscimo que ocorreu após 48 horas de fermentação pode ser devido a conversão de açúcares em ácidos orgânicos. Outras possibilidades incluem: sua utilização por microrganismos responsáveis pela fermentação ou ainda a sua hidrólise durante o processo. O aumento dos teores de açúcares no final da fermentação em relação a matéria-prima foi atribuído à produção de açúcares proveniente da degradação do amido. 
Ogunsua (1980) trabalhando com fermentação de mandioca para produção de gari, observou um aumento inicial na concentração de açúcares similarmente ao relatado por Oyewole \& Odunfa (1989).

\subsection{Aplicação de enzimas como modificadores do tecido vegetal}

Enzimas fúngicas ricas em celulase, pectinases e hemicelulases obtidas de diferentes microrganismos têm sido utilizadas em processos que visam a modificação reológica dos produtos alimentícios (Sharma \& Joseph, 1983).

A aplicação de enzimas pectinolíticas, mais precisamente as endopoligalacturonases, concentra-se em processos industriais que visam produção de sucos de frutas hortaliças e outros vegetais com turvidez estável, alimentos infantis e geriátricos, sopas desidratadas e molhos (Zetelaki-horvath \& Gatai, 1977), bem como reduzir a polpa indesejável de alimentos fibrosos (Dellweg ${ }^{1}$, citado por Kitagawa, 1991). A importância destas enzimas advém do fato de desintegrarem o tecido vegetal em células individuais ou aglomerados celulares (Zetelaki-horvath \& Gatai, 1977), sem destruição total da célula, mantendo o conteúdo intacto (Mc Clendon \& Sommers, 1960; Codner, 1971; Call et al., 1985).

Os preparados enzimáticos de celulases e pectinases obtidas de microrganismos disponíveis no mercado, são em geral uma mistura de várias carboidrases, tornando difícil interpretar e controlar a ação individual de cada enzima dentro de parâmetros de maceração e liquefação (Sreenath et al., 1984).

Visando verificar a influência de enzimas hidrolíticas (celulase, pectinase e poligalacturonase) na velocidade de fermentação de puba, Menezes et al. (1999) constataram que a adição de celulase e poligalacturonase no início do processo de pubagem, acelera a fermentação aumentando a acidez titulável e reduzindo o pH, mais rapidamente em relação a fermentação natural (sem adição de enzimas). Verificaram também a formação de celulase, xilanase e poligalacturonase, que tiveram suas atividades aumentadas no decorrer do processo.

A acentuada atividade da celulase e enzimas pectinolíticas como a pectina metil esterase e poligalacturonase, durante o andamento da fermentação de

\footnotetext{
${ }^{1}$ DELLWEG, H. G Rundlagen und verfahren der biotechnologie. Vorlesungen, Berlin. 1977.
} 
mandioca inoculada com cultura mista, facilita a maceração celular (George et al., 1992).

O efeito da fermentação no amolecimento das raízes e o envolvimento de enzimas proteolíticas no processo foram estudadas em detalhes por Bokanga et al. (1990). Constatando-se alterações de textura durante as primeiras 12 horas, indicando que microrganismos fermentadores podem induzir o amaciamento pela produção e ativação de enzimas responsáveis pelo processo. George (1994) relatou a habilidade do inóculo de cultura mista provocar amolecimento em sete variedades de mandioca estudadas durante a fermentação, facilitando a produção de farinha ácida fermentada.

Ampe \& Brauman (1995) concluíram que durante a fermentação natural as enzimas endógenas e microbianas agem juntas para amolecer as raízes de mandioca e para degradar compostos cianogênicos endógenos. Inicialmente ocorre a degradação da parede celular pela pectina esterase endógena, localizada no interior da planta e liberada pelo decréscimo do $\mathrm{pH}$. Em seguida as enzimas microbianas poligalacturonase e a poligalacturonato liase, despolimerizam as cadeias de pectina.

Brauman et al. (1995) concluíram que enzimas pectinolíticas de origem microbiana são indispensáveis no amolecimento completo das raízes de mandioca. A atividade significativa da pectinaesterase nas raízes frescas de mandioca e sua estabilidade durante a fermentação demostram sua origem na planta e indicam o seu envolvimento no amolecimento.

A influência da inoculação do líquido de maceração de processos anteriores, foi um dos fatores avaliados por Ampe et al. (1991), com o objetivo de padronização da fermentação, através do melhor controle da microflora e da drástica diminuição do pH causada por esta adição. Segundo os autores, o excesso de inóculo de fermentações prévias resulta em maceração incompleta, provavelmente pelo $\mathrm{pH}$ muito baixo para o desenvolvimento da microflora adequada. Neste trabalho adição de inóculo não diminuiu o tempo de maceração e não melhorou as qualidades organolépticas do fufu. 


\subsection{Temperatura e processo fermentativo}

Menezes et. al. (1999) estudando a influência de enzimas de maceração, celulase e pectinase, na produção de puba a temperatura ambiente $\left(20-22^{\circ} \mathrm{C}\right)$, observaram que o processo terminou entre 7 dias (168 horas) e 8 dias (192 horas).

Almeida (1992), relatou que a maioria das raízes de mandioca incubadas a $35^{\circ} \mathrm{C}$, fermentaram em 48 horas, mas a puba apresentou características organolépticas inferiores àquelas incubadas a $28-32^{\circ} \mathrm{C}$ que, segundo o autor, parece ser a temperatura mais adequada para produzir uma boa puba, apesar do período de fermentação ter se prolongado para 60 a 72 horas. Neste mesmo trabalho foram conduzidos experimentos em temperaturas de 34 a $38^{\circ} \mathrm{C}$, observando-se que a $38^{\circ} \mathrm{C}$ houve formação de gases na superfície ao final da fermentação, com odor pútrido e raízes com coloração amarelada, enquanto que a $34^{\circ} \mathrm{C}$ o cheiro era pútrido e azedo e as raízes flutuaram. Já em experimentos conduzidos a temperaturas superiores a $40^{\circ} \mathrm{C}$, tanto a maceração como a fermentação típicas, não ocorreram mesmo após o período de 96 horas. Em experimentos conduzidos em temperaturas de 24 a $26^{\circ} \mathrm{C}$, a fermentação e maceração ocorreram normalmente após 144 horas de incubação.

Ampe et al. (1994) relataram que a temperatura é um fator de muita influência no processo, indicando $34^{\circ} \mathrm{C}$ como temperatura ótima para uma maceração rápida. De acordo com os autores amostras de fufu tiveram qualidade organoléptica melhor (mais favorável) quando foram incubadas em temperaturas entre 28 e $37^{\circ} \mathrm{C}$.

Os resultados obtidos por Ampe et al. (1991), para produção do fufu, indicaram que a temperatura tem efeito muito importante no tempo de maceração e que a $32^{\circ} \mathrm{C}$ ocorreu uma considerável diminuição do tempo. Porém até $37^{\circ} \mathrm{C}$ o processo continuou rapidamente.

Experimentos realizados para produção de puba, por Menezes et al. (1998) conduzidos a temperatura ambiente de 14 a $18^{\circ} \mathrm{C}$, constataram que embora $\mathrm{O} p \mathrm{pH}$ tenha se estabilizado logo após o $7^{0}$ dia de pubagem, quando as raízes ainda se mantinham rígidas, a acidez titulável continuou a evoluir até o $17^{\circ}$ dia de fermentação. A fermentação foi mais prolongada em virtude das baixas temperaturas. 


\section{MATERIAL E MÉTODOS}

O experimento foi realizado no Laboratório de Amidos e Féculas do Departamento de Agroindústria, Alimentos e Nutrição, da Escola Superior de Agricultura "Luiz de Queiroz"/ Universidade de São Paulo.

\subsection{Material}

\subsubsection{Matéria-prima}

Raízes recém colhidas de mandioca (Manihot esculenta Crantz) da cultivar de Ouro do Vale (SRT-797) com cerca de 14 meses, provenientes da Região de Santa Maria da Serra, Interior do Estado de São Paulo, com boas características para consumo de mesa (Lorenzi \& Dias, 1993), foram selecionadas para este experimento (Figura 2).

\subsubsection{Enzima}

Foi utilizado preparado enzimático comercial de endopoligalacturonase 3.2.1.15 (Pectinex Ultra SP-L, fornecido pelo Novo Nordisk A/S) produzido por uma estirpe selecionada de Aspergillus aculeatus. Este preparado enzímico contém alta atividade pectinolítica e também atividade hemicelulolítica. Com atividade padrão máxima de $26000 \mathrm{PG} / \mathrm{mL}$ em pH 3,5 a $20^{\circ} \mathrm{C}$, atingindo a atividade de $173 \%$ em pH $3,5 \mathrm{a}$ $35^{\circ} \mathrm{C}$ (Novo Nordisk, 1997). 


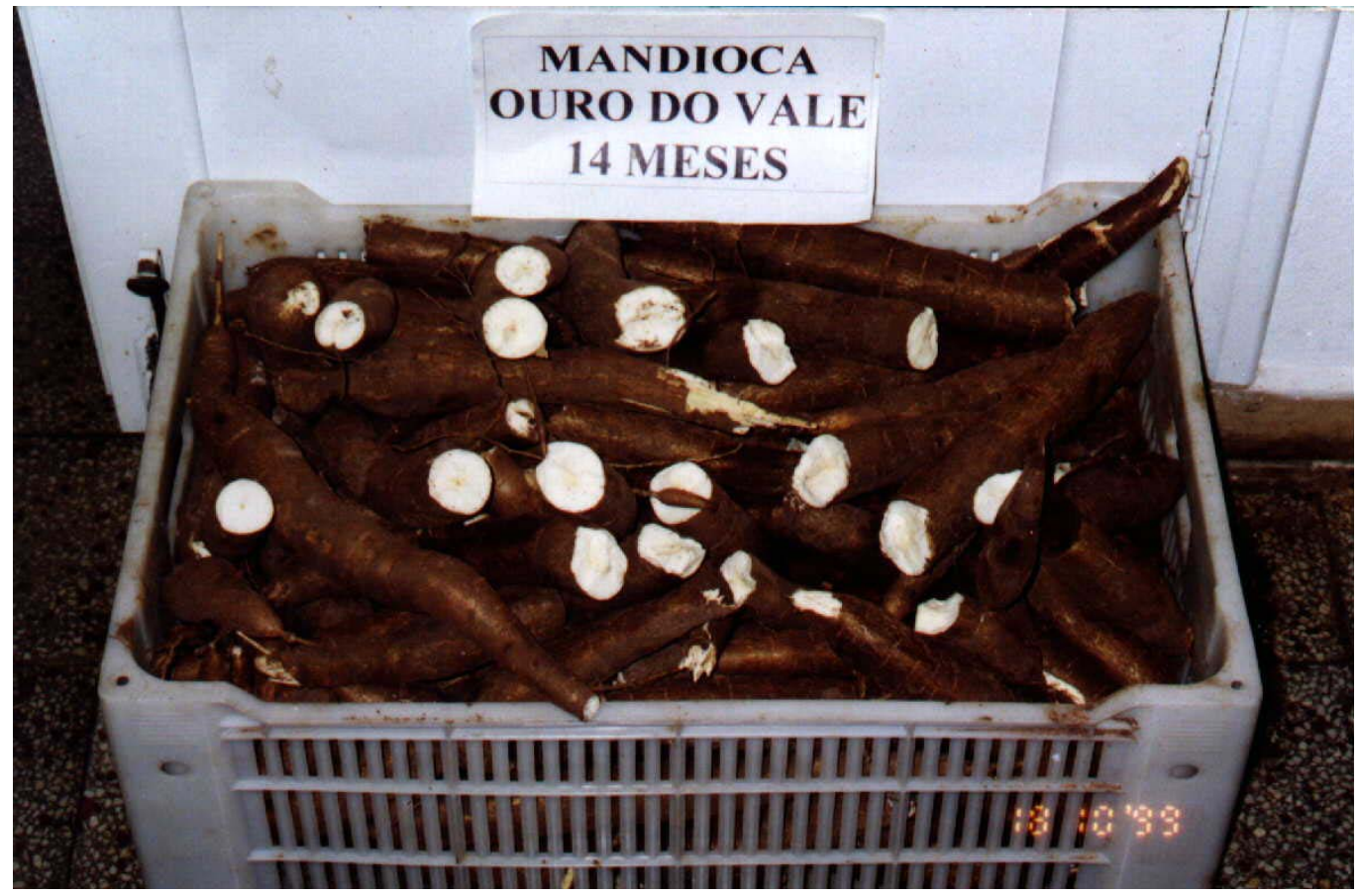

Figura 2 - Raízes de mandioca da cultivar Ouro do Vale.

\subsection{Métodos}

\subsubsection{Pubagem convencional e com adição de enzimas}

O procedimento utilizado para a produção de puba com e sem adição de pectinase obedeceu as seguintes etapas de processamento descritas no fluxograma abaixo (Figura 3).

As raízes foram descascadas, retirando-se apenas a película externa e cortando-se suas extremidades. Em seguida, foram lavadas e cortadas em pedaços uniformes de até aproximadamente $8 \mathrm{~cm}$ de espessura e $35-50 \mathrm{~g}$ de peso (Figura 4). Cerca de $1 \mathrm{Kg}$ de pedaços foi pesado em recipiente plástico com 3,5 litros de capacidade, onde foram adicionados 2 litros de água corrente por recipiente. 


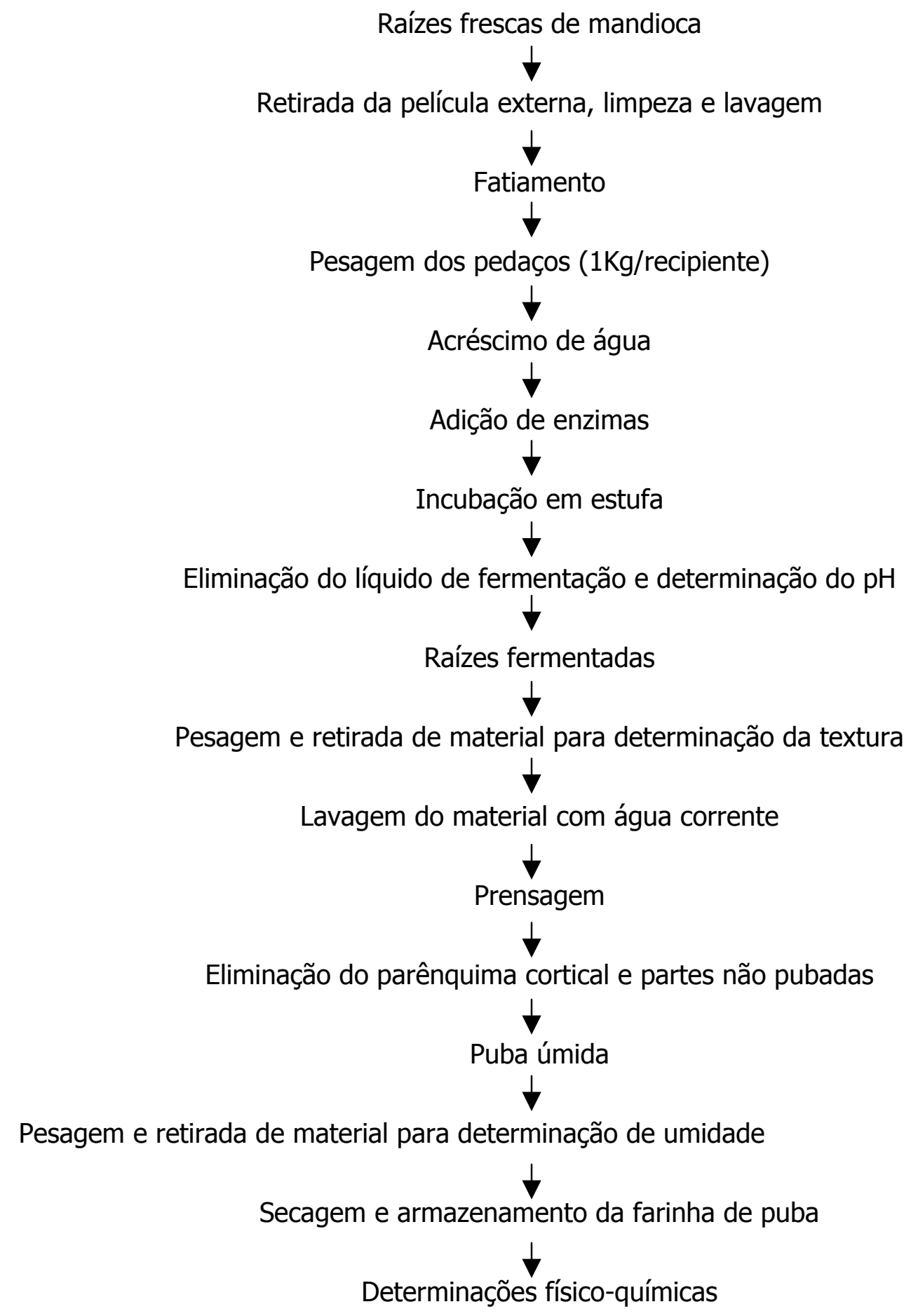

Figura 3 - Fluxograma de produção de puba. 


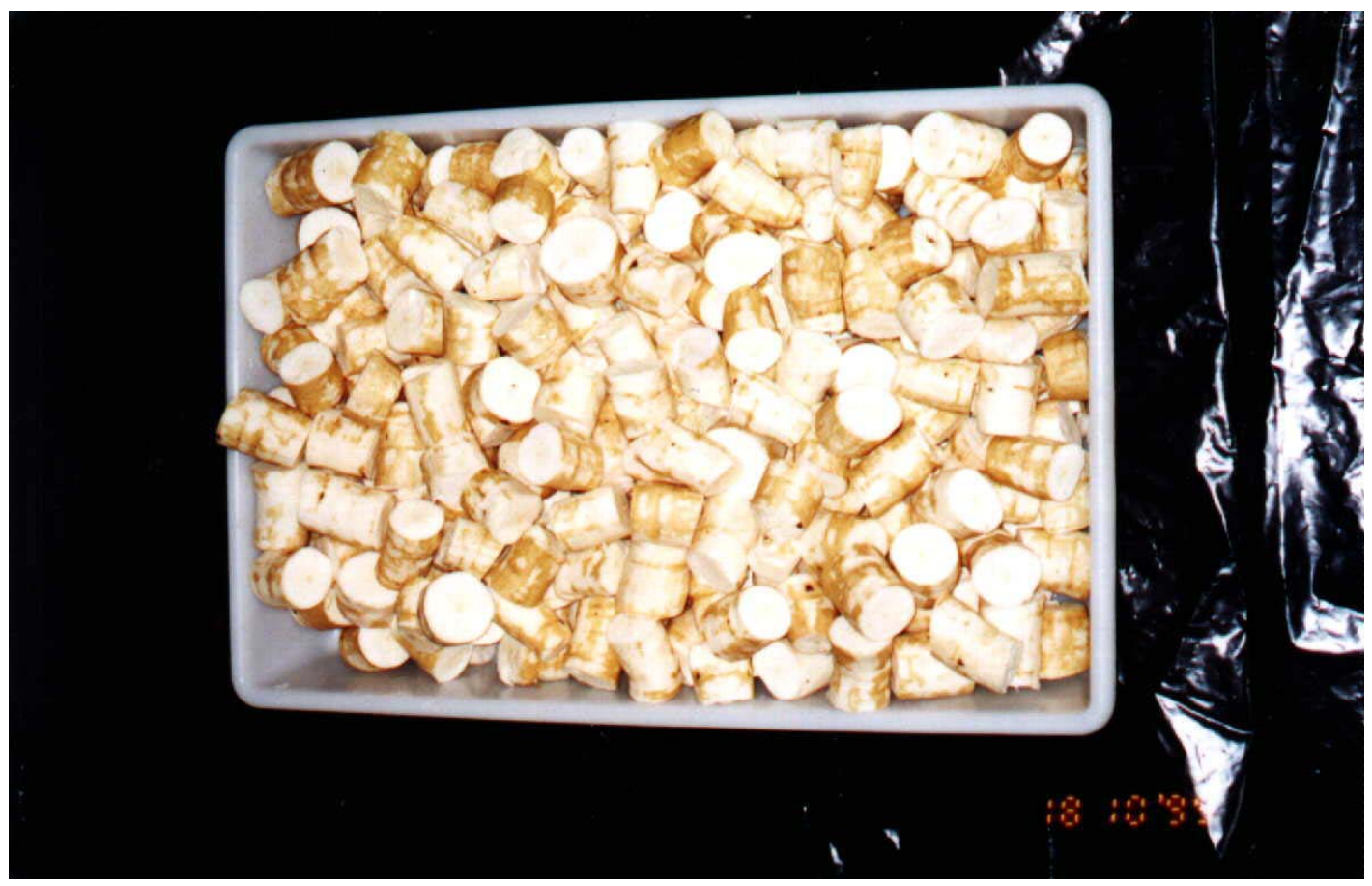

Figura 4 - Aspecto das raízes de mandioca cortadas para a pubagem.

Com o propósito de verificar a influência da enzima no processo de fermentação foi adicionado em cada tratamento 1 e $2 \mathrm{~mL}$ de enzima pectinase $/ \mathrm{Kg}$ de raiz. Ao tratamento controle (fermentação natural) não foi adicionada enzima. Após homogeneização, os sistemas foram incubados em estufa com temperaturas de 25, 30 e $35^{\circ} \mathrm{C}$ por 48,72 e 96 horas. No decorrer da fermentação os recipientes foram remanejados de lugar, aleatoriamente, dentro da estufa 2 vezes por dia.

Após o período determinado de incubação, o líquido de fermentação foi eliminado por drenagem por aproximadamente 1 hora com utilização de escorredouros plásticos (Figura 5). O material foi pesado e amostras de raízes pubadas foram retiradas para determinação da textura, e amostras do líquido para determinação do $\mathrm{pH}$. 


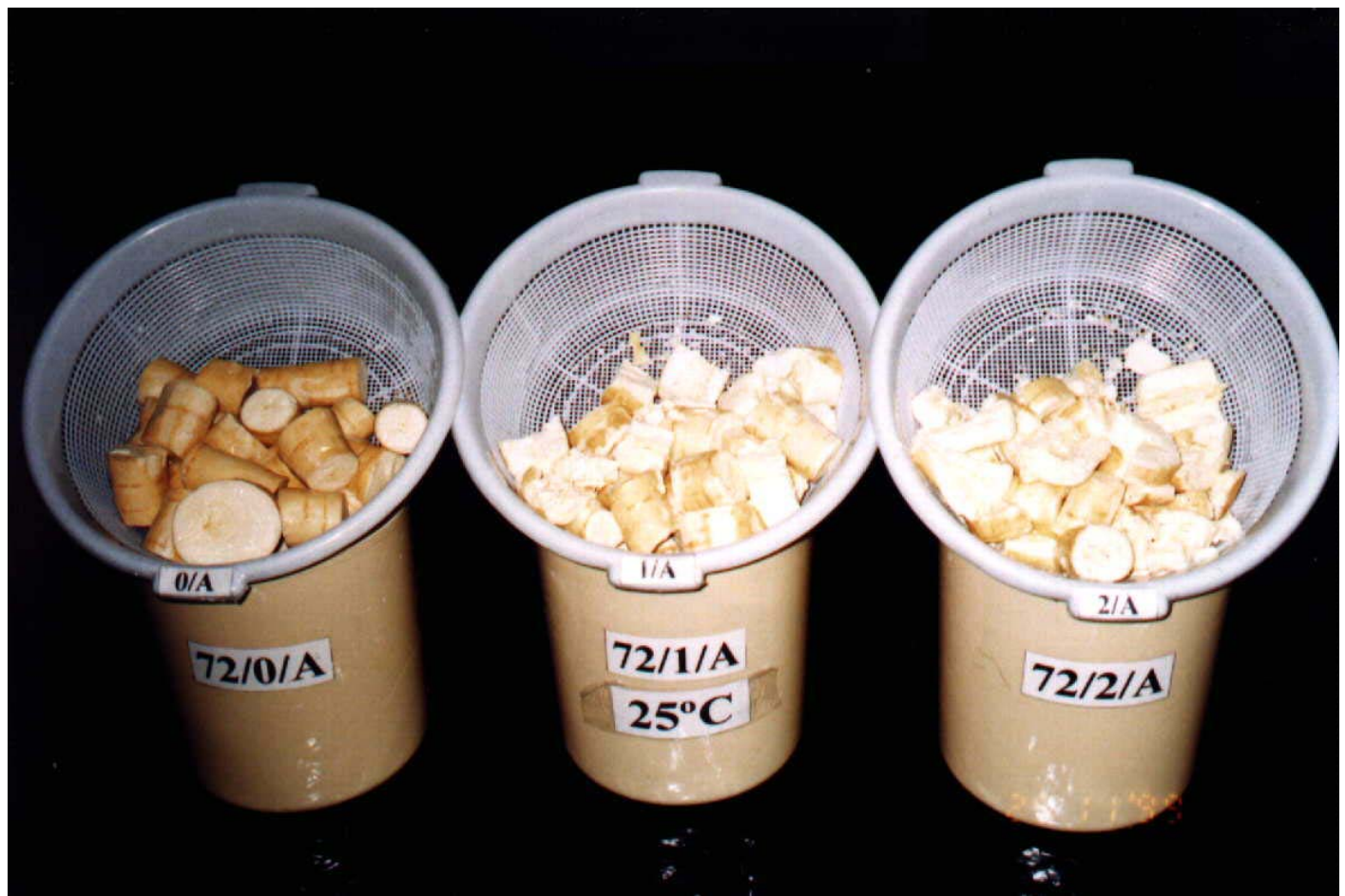

Figura 5 - Drenagem do líquido de fermentação.

Posteriormente, as raízes pubadas foram acondicionadas em saco de tecido de algodão e submetidas à lavagem, com 6 litros de água corrente (Figura 6). Em seguida o material foi prensado, no próprio tecido, e a massa resultante colocada em bandejas plásticas (Figura 7) para o processo de limpeza, eliminação do parênquima cortical e de partes não pubadas (Figura 8). Após a limpeza a massa final de puba foi pesada e amostras retiradas para determinação do teor de umidade para cálculo de rendimento. 


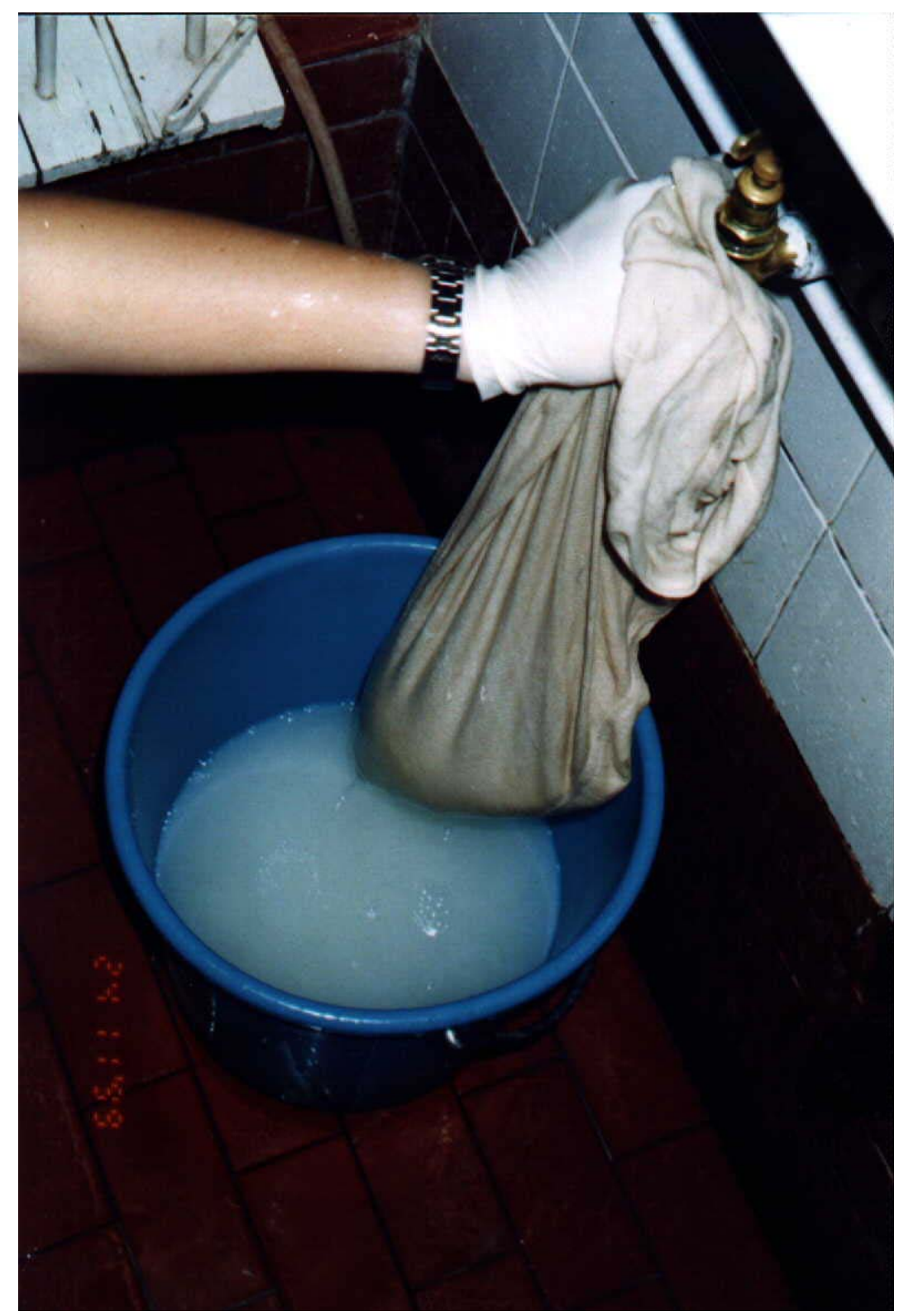

Figura 6 - Lavagem da puba.

\subsubsection{Acondicionamento das amostras}

As massas de puba resultantes de cada tratamento, foram acondicionadas em sacos plásticos individuais ao final do processo e congeladas à $-15^{\circ} \mathrm{C}$. Posteriormente as amostras foram descongeladas a temperatura ambiente e 
espalhadas sobre bandejas de aço inoxidável, sendo em seguida secas em estufa com circulação de ar forçado até atingirem umidade entre 7-9\%. Estes valores foram alcançados após aproximadamente $24-26$ horas à $35^{\circ} \mathrm{C}$ com homogeneização periódica da farinha nas bandejas. A massa desidratada foi moída em moinho da marca Tecnal (modelo TE) e armazenadas em recipientes de vidro tipo "snap-cap", para serem posteriormente submetidas as determinações de umidade, fibras insolúveis e solúveis, amido, amilose e açúcares solúveis totais.

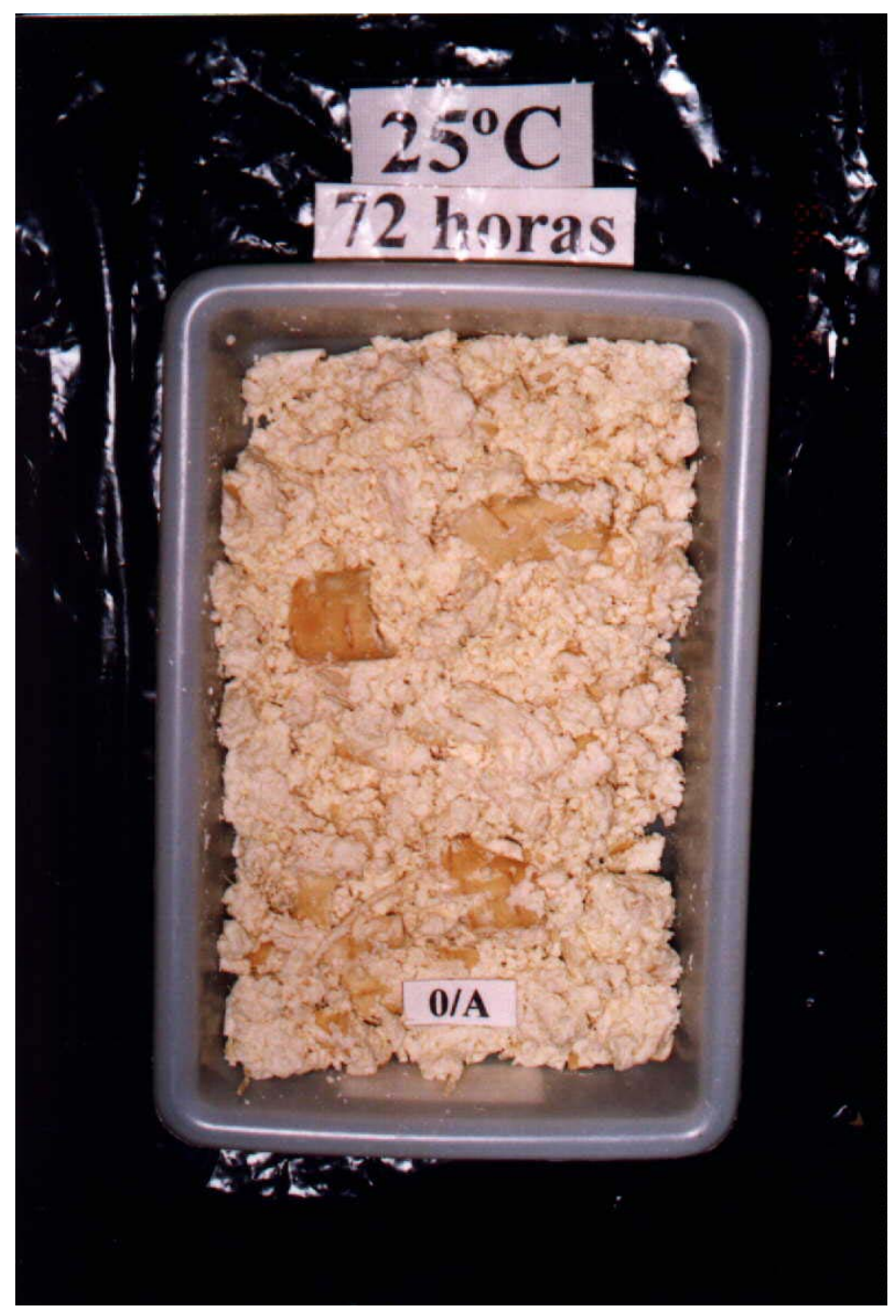

Figura 7 - Puba após lavagem e prensagem. 


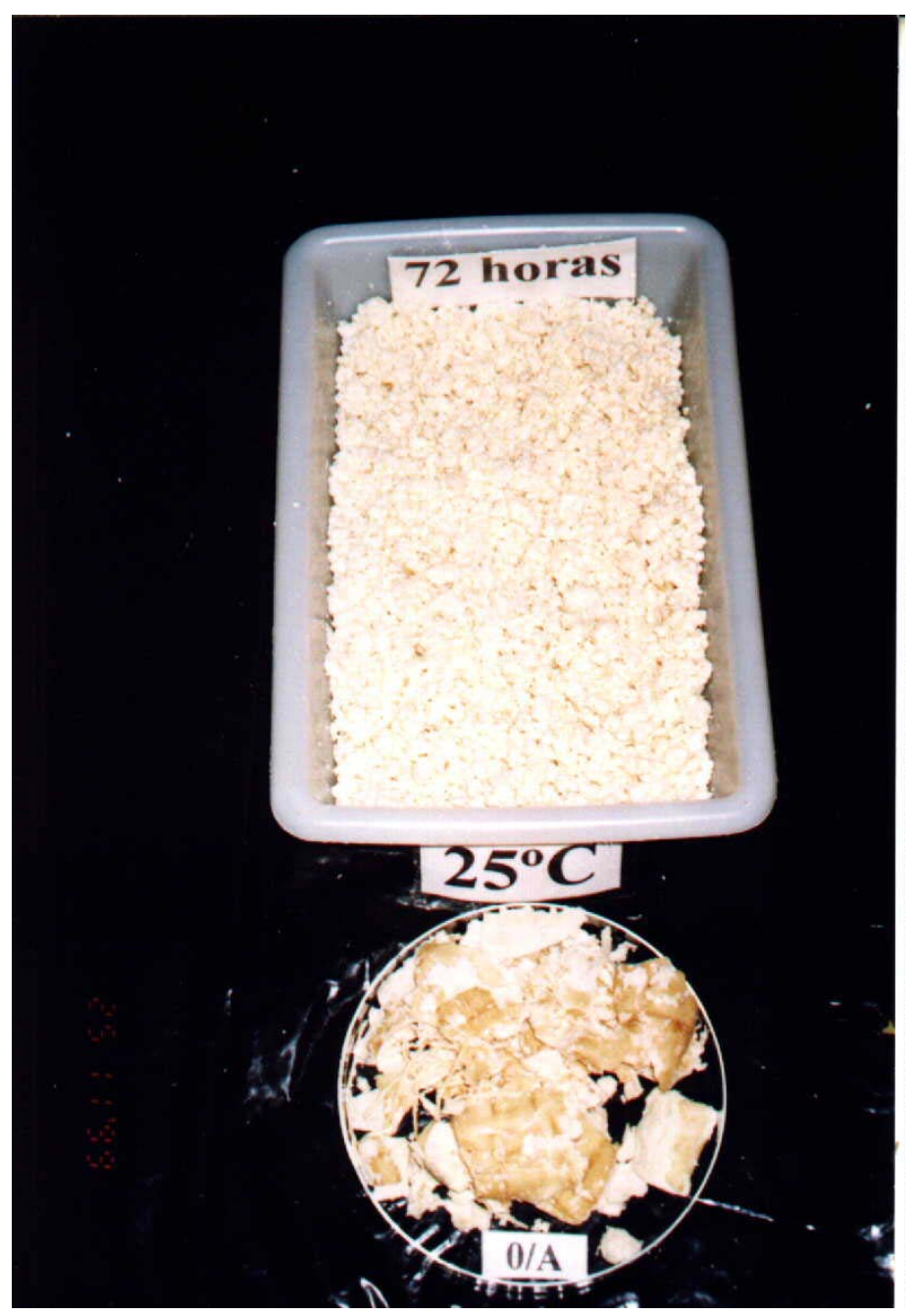

Figura 8 - Aspecto do produto final após retirada de partes não pubadas.

\subsubsection{Textura das raízes pubadas}

A avaliação da textura foi realizada em texturômetro "Texture Test System", modelo TP-1 acoplado a um registrador automático de variação de força, operando em célula-padrão de compressão de cisalhamento CS-1, com 10 lâminas de $1 / 8$ polegadas de espessura e ângulo de $90^{\circ}$. O instrumento era provido de um sensor eletrônico de 300, 1000 e 3000 libras-força (lbf). Para cada tempo de fermentação foi utilizado um sensor. A textura foi avaliada para cada tratamento ao final da incubação. 
Nesta ocasião quatro pedaços (fatias entre $40-50 \mathrm{~g}$ ) das raízes pubadas, foram amostrados aleatoriamente. As amostras eram previamente pesadas e colocadas na célula teste de cisalhamento e compressão, de tal forma que as lâminas das células tivessem ação paralela às fibras. As avaliações foram realizadas com o sensor eletrônico em 3000lbf no tempo inicial e com 48 horas de fermentação; 1000lbf com 72 horas de fermentação e 300lbf com 96 horas de fermentação. A velocidade de descida do pistão foi de $20 \mathrm{~cm} / \mathrm{min}$.

A força máxima de cisalhamento foi obtida da carta do registrador multiplicada pelo fator de posição do sensor eletrônico (3 se sensor em 300lbf, 10 se sensor em $1000 \mathrm{lbf}$ e 30 se sensor em $3000 \mathrm{lbf}$ ) e dividida pelo peso da amostra. Os resultados foram apresentados em lbf/g de amostra.

\subsubsection{Rendimento}

O rendimento foi calculado a partir da matéria seca das raízes e expresso em percentagem em base seca. Para efeito de cálculo de rendimento final, foi utilizado como referência (100\%) o peso das raízes na base seca no início do processo em relação ao peso da puba, na base seca, obtida após o processamento.

\subsubsection{Determinações químicas e físicas}

\subsubsection{1 pH}

$\mathrm{O}$ pH foi determinado em $20 \mathrm{~mL}$ do líquido de fermentação, utilizando-se potenciômetro da marca Beckmam-modelo zeromatic SS-3, de acordo com as Normas Analíticas do Instituto Adolfo Lutz (Pregnolato \& Pregnolato, 1986).

\subsubsection{Umidade}

Os teores de umidade foram determinados segundo normas da A.O.A.C. (1995). 


\subsubsection{Fibras}

Os teores de fibras solúveis e insolúveis foram determinados pelo método enzímico de ASP et al. (1983).

\subsubsection{Amido}

O teor de amido foi determinado pela hidrólise enzímica de acordo com metodologia descrita por Rickard \& Behn (1987) e o teor de açúcares dosado segundo Somogy e Nelson (Somogy, 1945).

\subsubsection{Amilose}

O teor de amilose foi realizado pela metodologia ISO 6647 (International Organization for Standartization, 1987).

\subsubsection{Açúcares solúveis totais}

Os açúcares solúveis foram extraídos utilizando-se solução de etanol $30 \%$ aquecido a $45^{\circ} \mathrm{C}$. Cinco gramas de amostra (base seca) moída foram pesadas e $35 \mathrm{~mL}$ da solução de etanol aquecido adicionado. Esta suspensão, foi levada a banhomaria a $40^{\circ} \mathrm{C}$ por 10 minutos, sob agitação constante. Após esfriar, o volume foi filtrado em papel de filtro quantitativo e lavado com $35 \mathrm{~mL}$ de solução de etanol aquecido. 0 volume recolhido foi colocado em estufa com circulação de ar forçado por uma noite. $O$ volume final foi transferido para balão volumétrico, completado o volume com água destilada e dosado o teor de açúcares solúveis pelo método fenol sulfúrico, descrito em Dubois et al. (1956).

\subsubsection{Delineamento Experimental}

Foram realizados 3 experimentos os quais diferiram na temperatura de incubação $\left(25,30\right.$ e $\left.35^{\circ} \mathrm{C}\right)$. Em cada um deles foi utilizado o delineamento experimental inteiramente casualizado com arranjo fatorial dos níveis testados (3X3), considerandose como fatores os tempos de incubação ( 48,72 e 96 horas) e as concentrações $(0,1$ e 
$2 \mathrm{~mL}$ de enzima comercial por $\mathrm{kg}$ de raiz). Os experimentos objetivaram avaliar o efeito dos fatores (tempo de incubação e concentração de enzima) sob o rendimento do processo e as características do produto obtido, os quais foram realizados em triplicata.

\subsubsection{Análise dos resultados}

Os dados obtidos foram analisados estatisticamente através do cálculos de médias, análise de variância e teste de TuKey. Os dados de textura e rendimento final também foram analisados estatisticamente através de equação de regressão e estudo de correlação. Foi adotado o nível de significância de $5 \%$ em todos os testes. As análises foram calculadas através do sistema SAS versão 8.0.

Realizou-se inicialmente um estudo de suposições através do programa SAS LAB para avaliar as exigências do modelo e adequar os dados obtidos. Os ajustes recomendados foram aplicados e são descritos em seguida.

Os valores de $\mathrm{pH}$ obtidos a $25^{\circ} \mathrm{C}$ foram ajustados elevando-se todos os dados $-7,5$.

Os valores de matéria seca obtidos a $25^{\circ} \mathrm{C}$ foram ajustados elevando-se todos os dados à potência -2.

Os valores de matéria seca obtidos a $30^{\circ} \mathrm{C}$ foram ajustados pela exclusão da observação obtida na $1^{\text {a }}$ repetição do ensaio conduzido por 96 horas tratado com $1 \mathrm{~mL}$ de enzima. 


\section{RESULTADOS E DISCUSSÃO}

Os resultados para cada repetição das determinações de matéria seca e textura das raízes pubadas, $\mathrm{pH}$ do líquido de fermentação bem como o rendimento final do processo estão compilados no Anexo $\mathrm{A}$.

Os resultados das determinações físico-químicas: teores de fibras insolúveis e solúveis, açúcares solúveis totais, amido e amilose \pm 0 erro padrão da média das amostras de puba desidratada estão compilados no Anexo B.

\subsection{Composição da matéria-prima}

A mandioca é uma cultura que apresenta muitas diferenças de constituição, tanto entre as variedades quanto dentro da mesma variedade. É uma matéria-prima de difícil utilização em condições de experimentos em laboratório, devido a falta de uniformidade, desde tamanho, forma, até a constituição, pois seus componentes chegam a variar dentro de uma mesma raiz.

As características das raízes de mandioca utilizadas como matéria-prima para a produção de puba, são apresentadas no Quadro 1. Os valores de $\mathrm{pH}$, textura e matéria seca foram determinados nas raízes frescas. Nas demais determinações foram utilizadas a farinha de mandioca moída na base seca (b.s.). 


\begin{tabular}{|l|r|}
\hline \multicolumn{1}{|c|}{ Características da mandioca } & \multicolumn{1}{c|}{ Média \pm e.p.**** } \\
\hline pH$^{*}$ & $\mathbf{6 , 2 2} \pm 0,080$ \\
\hline Textura lbf/g* & $\mathbf{1 8 , 6 2} \pm 0,797$ \\
\hline Matéria seca g/100g* & $\mathbf{3 9 , 3 0} \pm 0,401$ \\
\hline Fibra insolúvel g/100g* & $\mathbf{5 , 1 3} \pm 0,030$ \\
\hline Fibra solúvel g/100g* & $\mathbf{3 , 5 8} \pm 0,025$ \\
\hline Amido g/100g** & $\mathbf{8 8 , 9 1 ~} \pm 0,018$ \\
\hline Açúcares solúveis totais g/100g** & $\mathbf{2 , 4 0} \pm 0,010$ \\
\hline Amilose g/100g** & $\mathbf{1 4 , 0 5} \pm 0,016$ \\
\hline
\end{tabular}

Quadro 1 - Características físico-química da matéria-prima utilizada no processo.

$(*)$ Valores médios de 3 repetições \pm 0 erro padrão da média (e.p.***).

(**) Valores médio de 4 repetições \pm o erro padrão da média (e.p.***).

$(* * *)$ e.p. $=S / \sqrt{ } n \quad S^{2}=\left(\Sigma X^{2}-(\Sigma X)^{2} / n\right) / n-1 \quad n=n \cdot{ }^{0}$ de repetições.

\subsection{Acompanhamento do processo fermentativo}

\subsubsection{Características da fermentação}

Durante a fermentação da mandioca, alguns aspectos visuais e de odor puderam ser avaliados e comparados entre os parâmetros observados. Estes estão apresentados no Quadro 2 e nas Figuras 9, 10 e 11.

A presença de espuma de coloração branca na superfície (Figura 9), foi observada mais freqüentemente, nas primeiras 48 horas de fermentação para as três temperaturas, porém com maior intensidade nas fermentações naturais. Com 72 horas de fermentação, a quantidade diminuiu e passou para a tonalidade levemente amarelada (Figura 11). Com 96 horas não havia espuma na superfície do líquido em nenhuma das temperaturas e concentrações de enzima (Quadro 2). 


\begin{tabular}{|c|c|c|c|c|c|c|c|}
\hline $\begin{array}{c}\mathrm{T} \\
\left({ }^{\circ} \mathrm{C}\right)\end{array}$ & $\begin{array}{l}\text { Tempo } \\
\text { (h) }\end{array}$ & $\begin{array}{l}\text { Concen- } \\
\text { tração da } \\
\text { enzima } \\
(\mathrm{mL} / \mathrm{Kg})\end{array}$ & $\begin{array}{c}\text { Presença } \\
\text { de espuma } \\
\text { na } \\
\text { superfície } \\
\text { (Figuras } 9 \text { e } \\
11) \\
\end{array}$ & $\begin{array}{c}\text { Presença } \\
\text { de película } \\
\text { na } \\
\text { superfície } \\
\text { (Figura 10) }\end{array}$ & $\begin{array}{c}\text { Intensidade } \\
\text { coloração } \\
\text { branca } \\
\text { do líquido } \\
\text { (Figuras 6, 9, } 10 \\
\text { e11) }\end{array}$ & $\begin{array}{l}\text { Presença } \\
\text { de } \\
\text { pedaços } \\
\text { na } \\
\text { superfície } \\
\text { (Figuras } 910 \\
\text { e 11) }\end{array}$ & $\begin{array}{c}\text { Odor } \\
\text { característico }\end{array}$ \\
\hline \multirow{9}{*}{25} & \multirow{3}{*}{48} & 0 & Muita & Sem & "Muito Pouco & Sem & Suave \\
\hline & & 1 & Sem & Sem & Muito Pouco & Sem & Suave \\
\hline & & 2 & Pouca & Sem & Muito Pouco & Sem & Suave \\
\hline & \multirow{3}{*}{72} & 0 & Pouca & Sem & Pouco & Sem & Suave \\
\hline & & 1 & Sem & Sem & Pouco & Pouco & Médio \\
\hline & & 2 & Sem & Sem & Pouco & Pouco & Médio \\
\hline & \multirow{3}{*}{96} & 0 & Sem & Sem & Média & Pouco & Intenso \\
\hline & & 1 & Sem & Sem & Média & Pouco & Intenso \\
\hline & & 2 & Sem & Sem & Média & Pouco & Intenso \\
\hline \multirow{8}{*}{30} & \multirow[t]{2}{*}{48} & $\begin{array}{l}0 \\
1\end{array}$ & $\begin{array}{l}\text { Pouca } \\
\text { Pouca }\end{array}$ & $\begin{array}{l}\text { Sem } \\
\text { Sem }\end{array}$ & $\begin{array}{l}\text { Pouco } \\
\text { Pouco }\end{array}$ & $\begin{array}{l}\text { Muito } \\
\text { Muito }\end{array}$ & $\begin{array}{l}\text { Suave } \\
\text { Suave }\end{array}$ \\
\hline & & 2 & Pouca & Sem & Pouco & Muito & Suave \\
\hline & \multirow{3}{*}{72} & 0 & Sem & Sem & Pouco & Muito & Intenso \\
\hline & & 1 & Sem & Sem & Pouco & Muito & Intenso \\
\hline & & 2 & Sem & Sem & Média & Muito & Intenso \\
\hline & \multirow{3}{*}{96} & 0 & Sem & Com & Muito & Pouco & Acre \\
\hline & & 1 & Sem & Com & Muito & Pouco & Acre \\
\hline & & 2 & Sem & Com & Muito & Nenhum & Acre \\
\hline \multirow{9}{*}{35} & \multirow{3}{*}{48} & 0 & Muita & Sem & Pouco & Muito & Médio \\
\hline & & 1 & Pouca & Sem & Pouco & Muito & Médio \\
\hline & & 2 & Pouca & Sem & Médio & Muito & Médio \\
\hline & \multirow{3}{*}{72} & 0 & Pouca & Sem & Médio & Muito & Intenso \\
\hline & & 1 & Pouca & Sem & Médio & Muito & Intenso \\
\hline & & 2 & Pouca & Com & Muito & Pouco & Intenso \\
\hline & \multirow{3}{*}{96} & 0 & Sem & Com & Muito & Muito & Acre intenso \\
\hline & & 1 & Sem & Com & Muito & Pouco & Acre intenso \\
\hline & & 2 & Sem & Com & Muito & Pouco & Acre intenso \\
\hline
\end{tabular}

Quadro 2 - Características de aparência e odor da fermentação no decorrer do processo. 
Provavelmente, a adição de enzima causou alteração na microbiota presente nestes experimentos em relação aos experimentos nos quais ocorreu fermentação natural, para todas as temperaturas utilizadas. A presença de muita espuma na fermentação natural indica a presença de microrganismos formadores de gás.

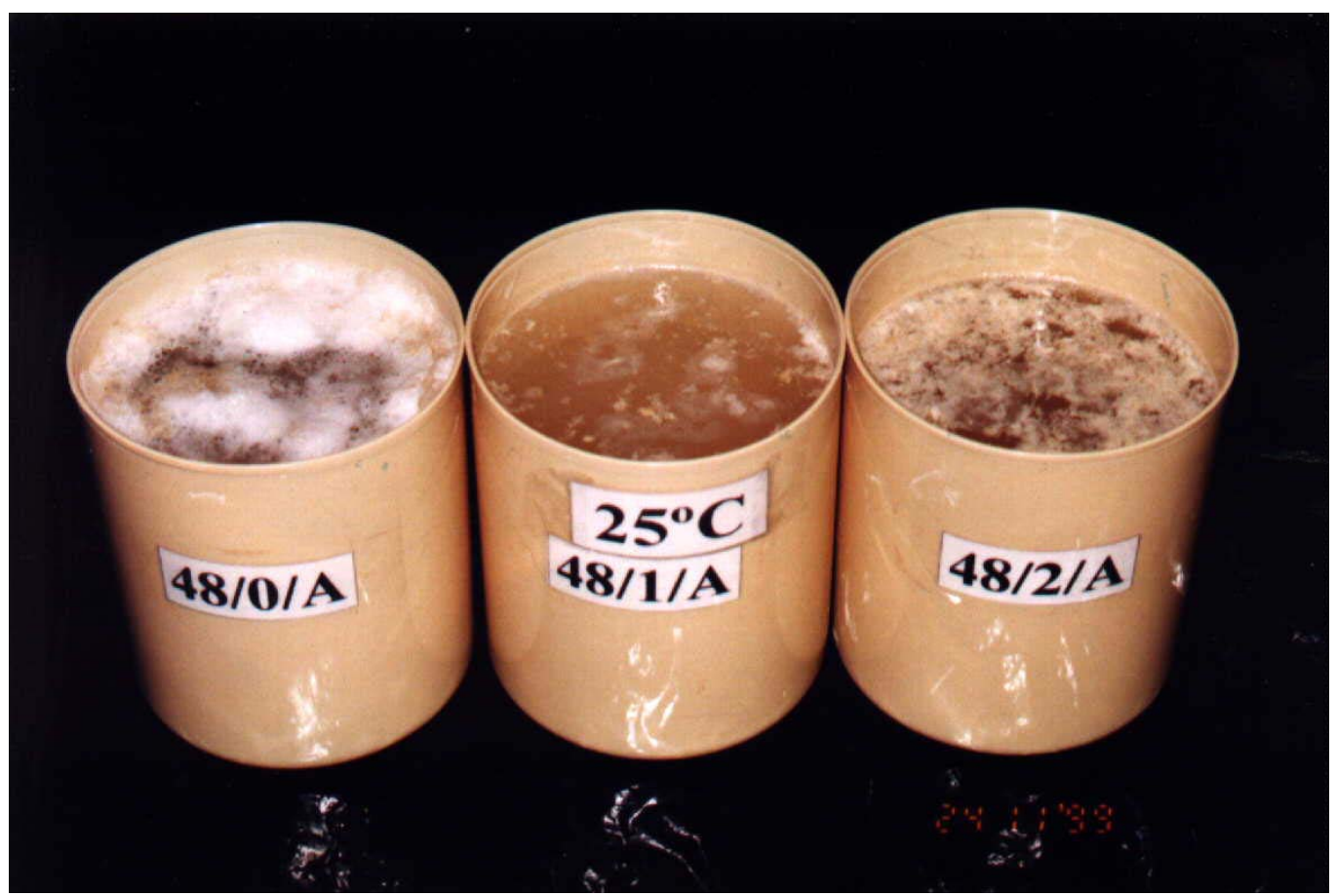

Figura 9 - Aspecto da espuma superficial.

$\mathrm{Na}$ temperatura de $25^{\circ} \mathrm{C}$, em nenhum tratamento foi observado formação de película, odor acre (azedo) ou excessiva turvidez do líquido drenado, provavelmente por esta temperatura ser menor que as outras e ocasionar uma fermentação mais lenta.

Segundo Almeida et al. (1987) provavelmente a presença de película e odores fortes e desagradáveis na fermentação, esteja relacionada ao crescimento de leveduras formadoras de película. 


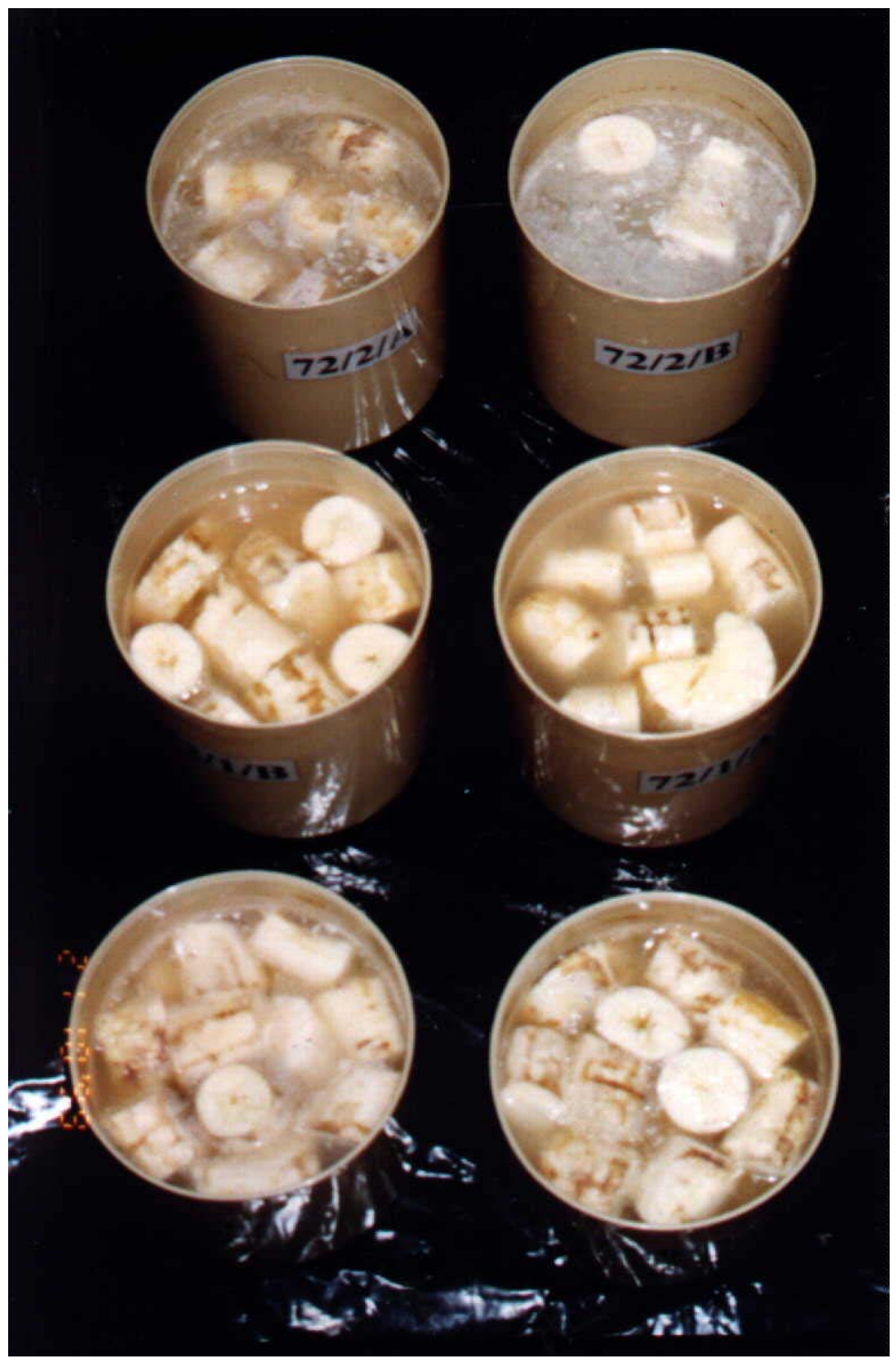

Figura 10 - Aspecto da película na superfície.

A formação de película na superfície (Figura 10) coincidiu com a presença de odor acre intenso (azedo acentuado) e com o aumento da turvidez do líquido de fermentação drenado, principalmente nos tratamentos com adição de $2 \mathrm{~mL}$ de enzima/Kg de raiz, no período de 72 horas para a temperatura de $35^{\circ} \mathrm{C}$, e em todos os tratamentos com 96 horas de incubação para 30 e $35^{\circ} \mathrm{C}$. Nestas condições as farinhas apresentavam-se com um aspecto pegajoso (viscoso) quando comparadas com a aparência das farinhas de puba obtidas em outras condições, que apresentavam-se soltas. 
A presença destas características somente com 96 horas de fermentação para as maiores temperaturas, pode estar relacionada com um período de incubação demasiadamente longo para obtenção da puba acarretando qualidades indesejáveis a mesma.

Almeida (1992) observou características semelhantes na fermentação da mandioca para produção de puba. O autor relata que em experimentos realizados a $38^{\circ} \mathrm{C}$ houve formação de gases na superfície ao final da fermentação, com odor pútrido apresentando-se as raízes amareladas, enquanto que a $34^{\circ} \mathrm{C}$ o cheiro era pútrido e acre.

Nas fermentações de vegetais, como na produção de picles, as leveduras formadoras de película, podem ocasionalmente aparecer na superfície da espuma e utilizar o ácido produzido pelos microrganismos, resultando em odor desagradável e produto de qualidade inferior (Prescott \& Dunn, 1959). Ainda não é conhecido o papel que essas leveduras exercem na fermentação da mandioca, mas pode-se especular que o problema não seja tão prejudicial, como em picles, se a massa de puba for desidratada posteriormente. Os compostos responsáveis pelo odor desagradável se volatilizariam na secagem, o que já não ocorreria no caso da puba consumida fresca.

Observou-se diferentes intensidades de turvidez do líquido de fermentação conforme o tratamento utilizado. Pode-se visualizar a diferença comparando-se a coloração do líquido mais branco ou turvo (Figura 11) para o líquido mais límpido (Figura 9).

Para todas as temperaturas, a turvidez da água foi tanto mais intensa quanto maior o período de incubação. A intensidade de turvidez com 48 horas de incubação foi maior quanto maior a temperatura, significando que períodos prolongados e temperaturas elevadas causam maiores perdas. A coloração branca da água de fermentação está associada a perda de amido (Brauman et al., 1995), o que pode ser constatado observando as Figuras 32, 34 e 35.

No início do processo (tempo zero), os pedaços de mandioca ao serem colocados nos recipientes plásticos permaneceram no fundo após a adição de água. Entretanto, no decorrer do processo, os pedaços de mandioca vieram a superfície, ou não, dependendo do tratamento. Nos experimentos conduzidos a $25^{\circ} \mathrm{C}$, não foram 
observados pedaços de raízes na superfície dos recipientes até 48 horas de fermentação, em todos os tratamentos. Com 72 horas de fermentação, alguns pedaços vieram a superfície e lá se mantiveram até 96 horas.

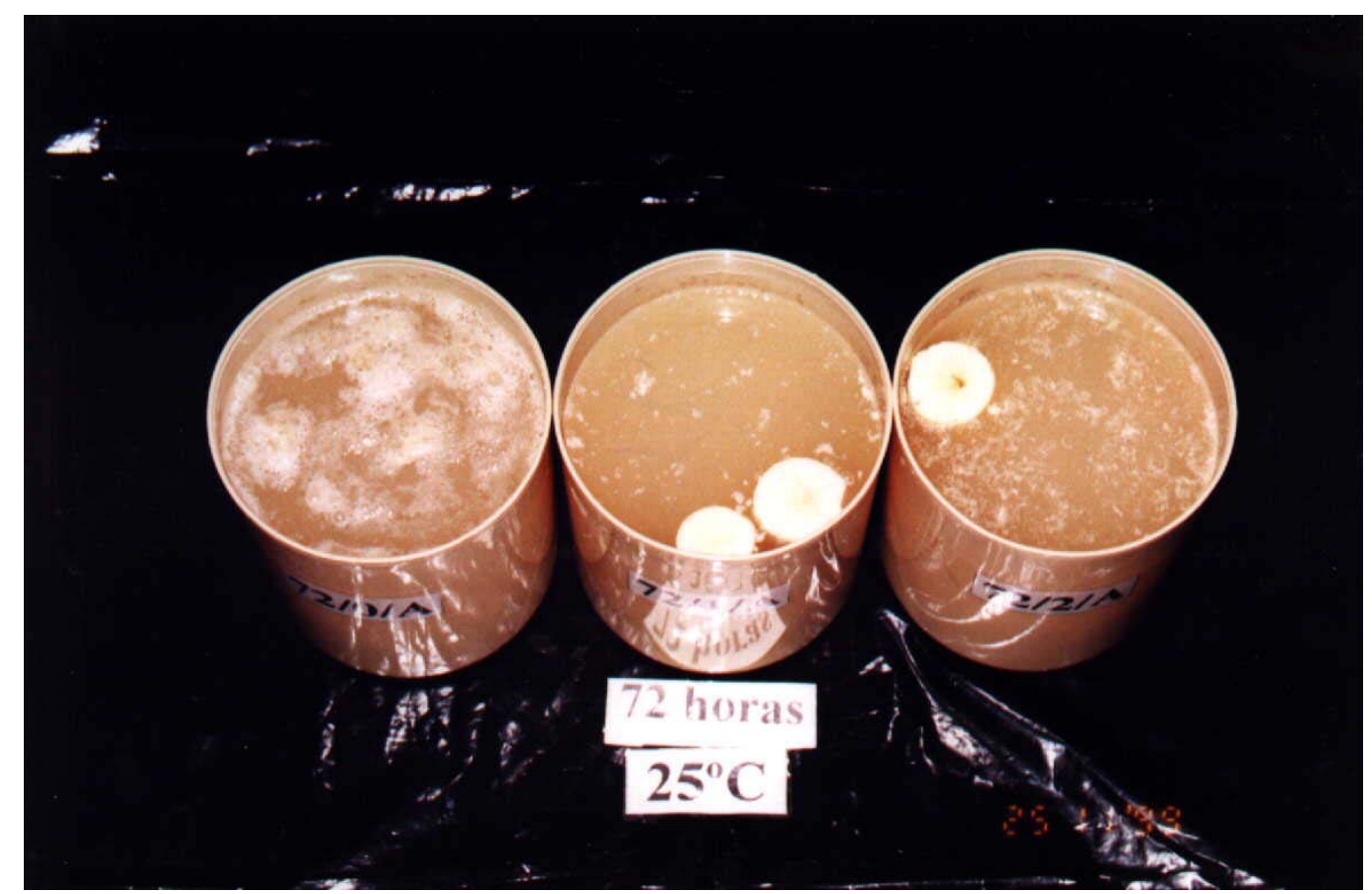

Figura 11 - Aspecto do líquido de fermentação - coloração esbranquiçada.

Para todos os tratamentos a $30^{\circ} \mathrm{C}$, muitos pedaços flutuaram nas primeiras 48 horas e lá se mantiveram até completar 72 horas de fermentação. Nesta mesma temperatura, na fermentação natural por 96 horas, apenas alguns pedaços se mantiveram na superfície, enquanto nos tratamentos com enzima nenhum pedaço veio a tona. Comportamento semelhante pôde ser observado para temperatura de $35^{\circ} \mathrm{C}$. Neste caso, com 72 horas de fermentação no tratamento adicionado de $2 \mathrm{~mL}$ de enzima/Kg de raiz, poucos pedaços vieram a superfície. Com 96 horas de incubação os tratamentos com enzima já não apresentavam nenhum pedaço na superfície, indicando fermentação excessiva das raízes. 
Pode-se supor que este comportamento dos pedaços de mandioca virem a superfície e voltarem a submergir (Figuras 10 e 11) poderia estar relacionado com o término do processo fermentativo. Pubas prontas boiariam e pubas demasiadamente fermentadas voltariam a submergir. É possível que haja uma relação entre esta característica e a densidade da mandioca e entre esta e a textura, mas não foi possível correlacionar precisamente estas características com o fim da fermentação.

Almeida (1992) também relatou presença de raízes flutuando durante a fermentação da mandioca para produção de puba a $34^{\circ} \mathrm{C}$ por 60 a 72 horas, além do cheiro pútrido e azedo.

A intensidade dos odores aumenta com o tempo de fermentação, e com o aumento da temperatura. Entretanto odores acre e acre intenso, os quais não são desejáveis neste processo, foram observados nas fermentações por 96 horas a $30^{\circ} \mathrm{C} \mathrm{e}$ $35^{\circ} \mathrm{C}$, respectivamente. Estas observações podem indicar que nestas temperaturas o período de 96 horas seja demasiadamente longo e provavelmente já esteja ocorrendo a putrefação do material. É oportuno ressaltar que os menores rendimentos tanto a $30^{\circ} \mathrm{C}$ como a $35^{\circ} \mathrm{C}$ foram no período de 96 horas de incubação com o tratamento de $2 \mathrm{~mL}$ de enzima/Kg de raiz (Figuras 23 e 24).

Ampe et al. (1994) concluíram que o tempo de fermentação e a temperatura tiveram forte efeito nas características não só visuais mas de sabor e aroma do fufu. Os autores relataram que obtiveram qualidade organoléptica melhor quando foram usadas temperaturas de incubação entre 28 e $32^{\circ} \mathrm{C}$.

Almeida (1992) relatou que a maioria das raízes de mandioca incubadas a $35^{\circ} \mathrm{C}$ fermentou em 48 horas, mas a puba apresentou características organolépticas inferiores àquelas incubadas a $28-32^{\circ} \mathrm{C}$ que, segundo o autor, parece ser a faixa de temperatura mais adequada para produzir puba com boa qualidade, apesar do período de fermentação ter se prolongado por 60 a 72 horas.

\subsubsection{Valores de pH do líquido de fermentação}

Os valores de pH foram medidos no líquido de fermentação adicionado ou não de enzima, no início do processo e no líquido de fermentação da puba, após cada período de incubação. 
$\mathrm{O} \mathrm{pH}$ do líquido no início do processo foi de 6,87 para o tratamento testemunha e de 6,70 e 6,80 para os tratamentos com 1 e $2 \mathrm{~mL}$ de enzima/Kg de raiz respectivamente.

Em todos os tratamentos houve um acentuado decréscimo do $\mathrm{pH}$ durante as primeiras 48 horas de incubação, após este período, entretanto, a acidificação prosseguiu mais lentamente, e ao final de 96 horas de processo, para os diversos tratamentos, os valores mínimos se situaram numa faixa próxima a 3,73-3,87, comportamento visualizado nas Figuras 12, 13 e 14. Os valores encontrados por Olivieri et al. (1999) para diversas amostras de puba fermentada com 72 horas variou de 4,1 a 4,7 .

Os valores médios de $\mathrm{pH}$ obtidos nas fermentações a $25^{\circ} \mathrm{C}$ estão representados na Tabela 1. Para esta temperatura os valores de pH oscilaram de 4,26 com 48 horas a 3,93 com 96 horas de incubação, no tratamento testemunha. Os tratamentos com 1 e $2 \mathrm{~mL}$ de enzima/Kg de raiz apresentaram comportamento semelhante, não tendo diferido estatisticamente entre si, apesar de terem decrescido com o aumento do tempo.

Tabela 1. Valores de pH das fermentações a $25^{\circ} \mathrm{C}$.

\begin{tabular}{ccccc}
\hline \multirow{2}{*}{ Tempo (h) } & \multicolumn{3}{c}{$\mathrm{pH} \pm$ e.p.* } & \multirow{2}{*}{ Média } \\
\cline { 2 - 4 } & 0 & 1 & 2 & \\
\cline { 2 - 4 } & $4,26 \pm 0,007$ & $4,14 \pm 0,031$ & $4,14 \pm 0,043$ & $4,18^{\mathrm{a}}$ \\
78 & $4,19 \pm 0,064$ & $4,05 \pm 0,013$ & $3,94 \pm 0,035$ & $4,06^{\mathrm{b}}$ \\
96 & $3,93 \pm 0,033$ & $3,80 \pm 0,100$ & $3,73 \pm 0,088$ & $3,82^{\mathrm{c}}$ \\
Média & $4,12^{\mathrm{A}}$ & $3,99^{\mathrm{B}}$ & $3,93^{\mathrm{B}}$ & \\
\hline
\end{tabular}

$\left(^{*}\right)$ Valores médios de três repetições \pm 0 erro padrão da média. Valores médios seguidos de letras minúsculas comparam médias dentro de cada tempo e, seguidos de letras maiúsculas comparam médias dentro de cada concentração de enzima, ao nível de $5 \%$ pelo teste de Tukey.

e.p. $=S / \sqrt{ } n \quad S^{2}=\left(\Sigma X^{2}-(\Sigma X)^{2} / n\right) / n-1 \quad n=n .^{\circ}$ de repetições

A diminuição dos valores de $\mathrm{pH}$ durante a fermentação tem sido relatada por vários pesquisadores (Almeida, 1992; Brauman et al., 1995; Menezes et al., 1998; 
Olivieri et al., 1999). Conforme esperado, os valores de $\mathrm{pH}$ obtidos dos líquidos de fermentação reduziram com o tempo de incubação para todas as temperaturas.

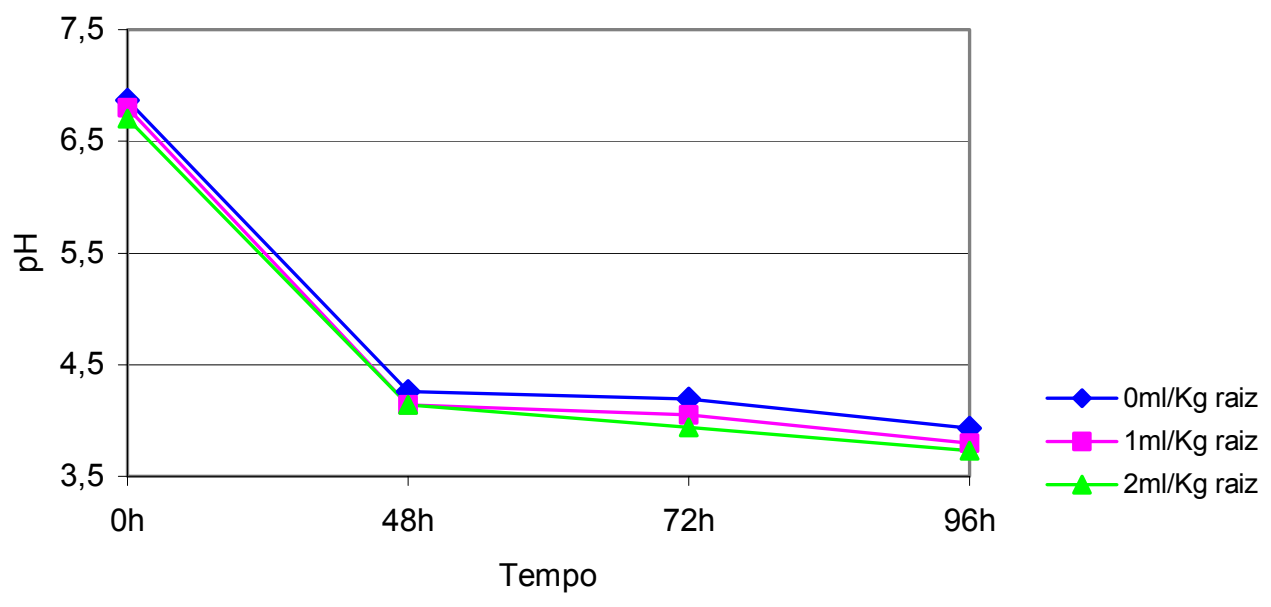

Figura 12 - Valores de pH das fermentações a $25^{\circ} \mathrm{C}$.

Os valores médios de $\mathrm{pH}$ obtidos nas fermentações a $30^{\circ} \mathrm{C}$ estão apresentados na Tabela 2. Para esta temperatura, o maior valor de $\mathrm{pH}$ foi 4,30, obtido com 48 horas de incubação adicionado de $1 \mathrm{~mL}$ de enzima. Com 96 horas o pH foi 3,87 para os dois tratamentos com enzima.

Tabela 2. Valores de pH das fermentações a $30^{\circ} \mathrm{C}$.

\begin{tabular}{ccccc}
\hline & \multicolumn{4}{c}{ pH \pm e.p.* } \\
Tempo (h) & \multicolumn{2}{c}{ Média } \\
\cline { 2 - 4 } & 0 & 1 & \\
\cline { 2 - 4 } & $4,18 \pm 0,104$ & $4,30 \pm 0,073$ & $4,19 \pm 0,108$ & $4,22 \mathrm{a}$ \\
72 & $4,21 \pm 0,031$ & $4,04 \pm 0,023$ & $3,99 \pm 0,007$ & $4,08 \mathrm{~b}$ \\
96 & $4,03 \pm 0,033$ & $3,87 \pm 0,033$ & $3,87 \pm 0,033$ & $3,92 \mathrm{c}$ \\
Média & 4,14 & 4,07 & 4,01 & \\
\hline
\end{tabular}

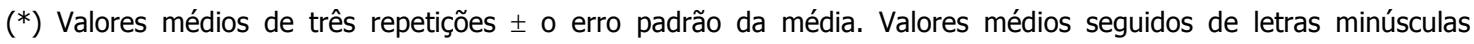
comparam médias dentro de cada tempo e, seguidos de letras maiúsculas comparam médias dentro de cada concentração de enzima, ao nível de $5 \%$ pelo teste de Tukey.

e.p. $=S / \sqrt{ } n \quad S^{2}=\left(\Sigma X^{2}-(\Sigma X)^{2} / n\right) / n-1 \quad n=n .^{\circ}$ de repetições 
No entanto, na fermentação natural houve um ligeiro aumento entre 48 e 72 horas, seguido de diminuição com 96 horas de incubação. A Figura 13 representa o comportamento dos valores de $\mathrm{pH}$ a $30^{\circ} \mathrm{C}$.

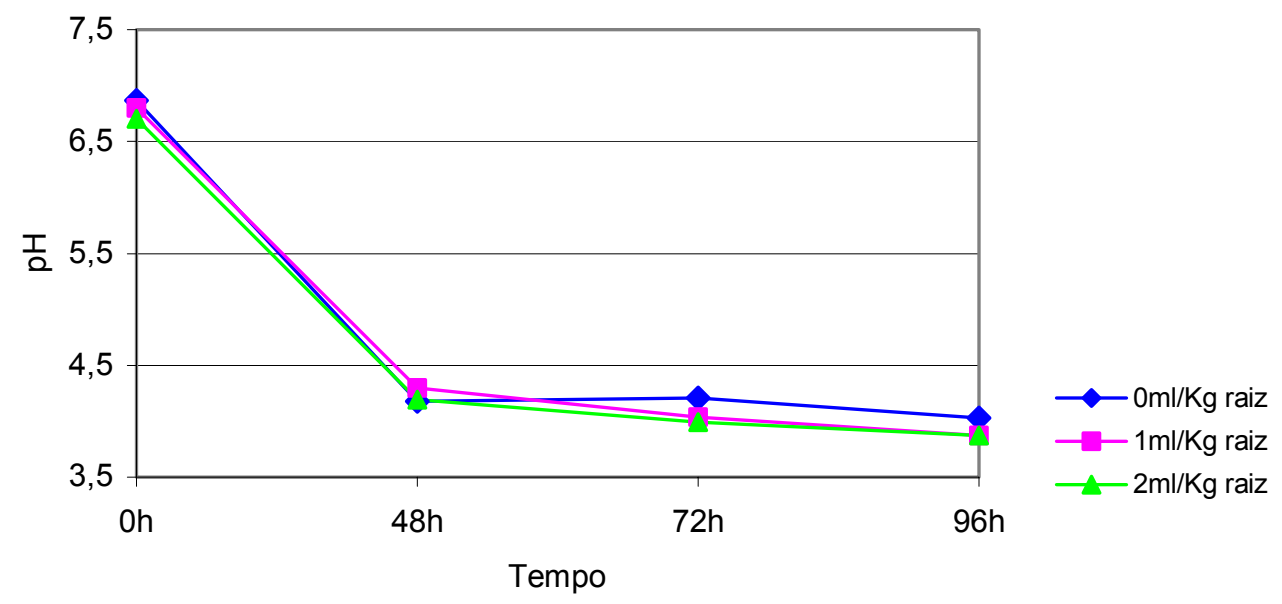

Figura 13 - Valores de pH das fermentações a $30^{\circ} \mathrm{C}$.

Os valores médios de $\mathrm{pH}$ obtidos nas fermentações a $35^{\circ} \mathrm{C}$ estão representados na Tabela 3 e Figura 14 . Assim como para $25^{\circ} \mathrm{C}$, o valor mais elevado de pH após início do processo ocorreu com 48 horas no tratamento testemunha, e o menor valor com 96 horas de fermentação no tratamento adicionado de $2 \mathrm{~mL}$ de enzima onde parece haver maior formação de ácidos orgânicos.

$\mathrm{O}$ decréscimo dos valores de $\mathrm{pH}$ foi mais acentuado nos tratamentos adicionados de enzima, principalmente no tratamento com $2 \mathrm{~mL}$ de enzima/Kg de raiz para todas as temperaturas. Resultados semelhantes foram encontrados por Olivieri et al. (1999) e Menezes et al. (1999) que constataram que a adição de enzimas reduziu o pH mais rapidamente em relação ao tratamento sem adição de enzimas. 
Tabela 3. Valores de pH das fermentações a $35^{\circ} \mathrm{C}$.

\begin{tabular}{ccccc}
\hline & \multicolumn{3}{c}{$\mathrm{pH} \pm$ e.p.* } & \multirow{2}{*}{ Média } \\
\cline { 2 - 3 } Tempo $(\mathrm{h})$ & \multicolumn{2}{c}{ Concentração de enzima (mL/Kg de raiz) } & \\
\cline { 2 - 3 } & 0 & 1 & 2 & $4,13^{\mathrm{a}}$ \\
\cline { 2 - 4 } 78 & $4,30 \pm 0,036$ & $4,13 \pm 0,020$ & $3,97 \pm 0,055$ & $4,00^{\mathrm{ab}}$ \\
96 & $4,17 \pm 0,031$ & $4,01 \pm 0,122$ & $3,84 \pm 0,081$ & $3,92^{\mathrm{b}}$ \\
Média & $4,07 \pm 0,120$ & $3,88 \pm 0,109$ & $3,83 \pm 0,133$ & \\
\hline
\end{tabular}

$\left(^{*}\right)$ Valores médios de três repetições \pm 0 erro padrão da média. Valores médios seguidos de letras minúsculas comparam médias dentro de cada tempo e, seguidos de letras maiúsculas comparam médias dentro de cada concentração de enzima, ao nível de $5 \%$ pelo teste de Tukey.

e.p. $=S / \sqrt{ } n \quad S^{2}=\left(\Sigma X^{2}-(\Sigma X)^{2} / n\right) / n-1 \quad n=n \cdot{ }^{\circ}$ de repetições

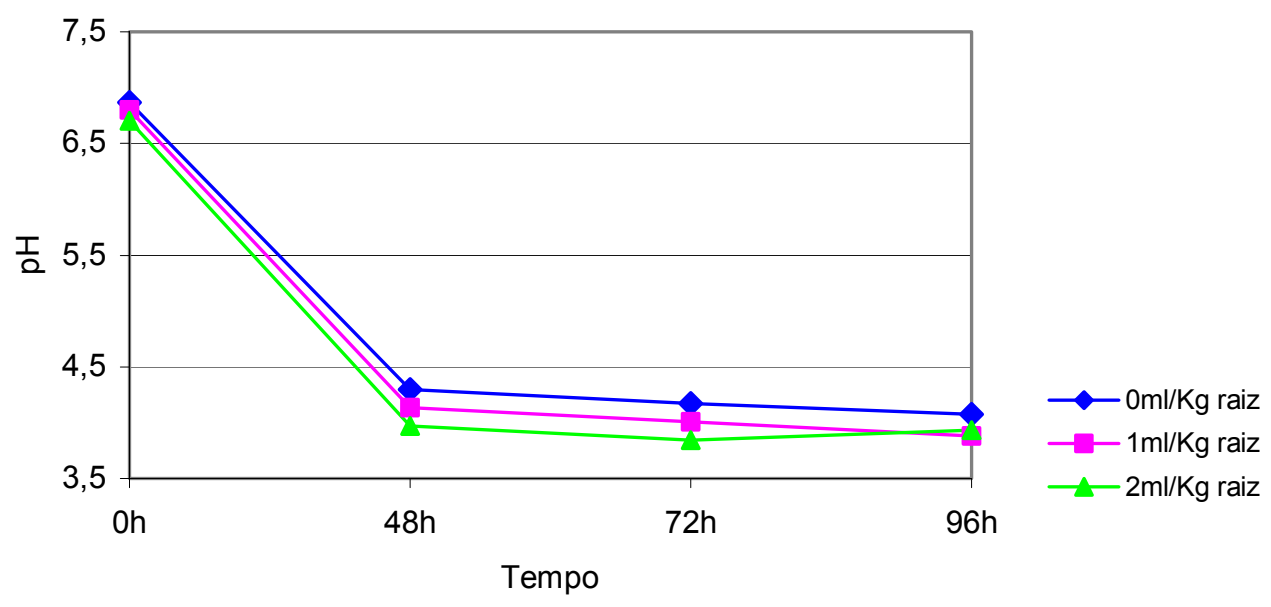

Figura 14 - Valores de pH das fermentações a $35^{\circ} \mathrm{C}$.

O abaixamento do pH em fermentações naturais é atribuído à produção de ácidos orgânicos pela microbiota responsável pela fermentação (Akinrele, 1964; Ampe et al., 1994; George et al., 1995). Adicionando-se enzimas adequadas o processo de maceração é acelerado, resultando em maior produção de ácidos pelo microrganismos e consequentemente um abaixamento mais rápido dos valores de $\mathrm{pH}$. 
A Tabela 4 demonstra os resultados da análise estatística e valores de $F$, para os valores de $\mathrm{pH}$, das fermentações a 25,30 e $35^{\circ} \mathrm{C}$.

Tabela 4. Análise estatística dos valores de pH.

\begin{tabular}{llll}
\hline \multicolumn{1}{c}{ Causas de variação } & \multicolumn{3}{c}{ Valores de $\mathrm{F}$} \\
\hline \multicolumn{1}{c}{ Temperatura } & $25^{\circ} \mathrm{C}$ & $30^{\circ} \mathrm{C}$ & $35^{\circ} \mathrm{C}$ \\
\hline Tempo & $36,08^{* *}$ & $18,71^{* *}$ & $4,16^{*}$ \\
Concentração de enzima & $11,45^{* *}$ & $3,17^{\text {n.s. }}$ & $8,33^{* *}$ \\
Tempo $\times$ Concentração de enzima & $0,72^{\text {n.s. }}$ & $2,02^{\text {n.s. }}$ & $0,15^{\text {n.s. }}$ \\
\hline ** significativo ao nível de $1 \%$ & Coeficiente de & Coeficiente de & Coeficiente de \\
* significativo ao nível de 5\% $^{*}$ n.s.: não significativo ao nível de $5 \%$ & variação: 15,35 & variação: 2,563 & variação: 3,831
\end{tabular}

$\mathrm{Na}$ análise de variância, para $25^{\circ} \mathrm{C}$, o efeito da enzima e do tempo foi significativo $(p<0,05)$. Entretanto, o efeito da interação tempo $X$ enzima não foi significativo ( $p>0,05)$, indicando que a ação da enzima não foi influenciada pelo tempo de fermentação. Provavelmente, a interação não tenha sido significativa na fermentação a $25^{\circ} \mathrm{C}$ porque esta temperatura não se encontra na faixa mais adequada para atividade máxima da enzima de maceração.

$\mathrm{Na}$ temperatura de $30^{\circ} \mathrm{C}$ apenas o efeito do tempo foi significativo $(p<0,05)$, provavelmente porque esta é mais adequada para a fermentação.

Os resultados da análise estatística e valores de $\mathrm{F}$ das fermentações a $35^{\circ} \mathrm{C}$ mostram que o efeito isolado da enzima foi significativo $(p<0,05)$, assim como 0 tempo. Entretanto o efeito da interação tempo $X$ enzima não foi significativo $(p>0,05)$. Para as três temperaturas a interação não foi significativa, indicando a independência na atuação dos fatores testados no comportamento dos valores de $\mathrm{pH}$ ao longo da fermentação.

\subsubsection{Teores de matéria seca das raízes pubadas}

Em virtude das raízes permanecerem submersas em água durante a maceração, é de se esperar que alterações nos teores de matéria seca possam ocorrer. 
Os teores de matéria seca determinados nas raízes pubadas, após a drenagem do líquido de fermentação, a $25^{\circ} \mathrm{C}$ estão apresentados na Tabela 5 e Figura 15 , para o processamento a $30^{\circ} \mathrm{C}$ na Tabela 8 e Figura 16 , e a $35^{\circ} \mathrm{C}$ na Tabela 9 e Figura 17.

Houve acentuada queda dos teores de matéria seca com 48 horas de incubação principalmente nos tratamentos com $1 \mathrm{~mL}$ de enzima/Kg de raiz (Figura 15).

Tabela 5. Valores de matéria seca das raízes durante processo de fermentação a $25^{\circ} \mathrm{C}$.

\begin{tabular}{cccc}
\hline \multirow{2}{*}{ Tempo (h) } & \multicolumn{3}{c}{ Matéria seca (\%) \pm e.p.* } \\
\cline { 2 - 4 } & \multicolumn{3}{c}{ Concentração de enzima (mL/Kg de raiz) } \\
\cline { 2 - 4 } & 0 & 1 & 2 \\
\hline 48 & $40,32 \pm 1,151$ & $40,88 \pm 1,416$ & $39,07 \pm 1,785$ \\
72 & $38,36 \pm 0,427$ & $38,94 \pm 0,626$ & $38,43 \pm 0,360$ \\
96 & $37,31 \pm 0,632$ & $36,85 \pm, 564$ & $37,92 \pm 0761$ \\
\hline
\end{tabular}

$\left(^{*}\right)$ Valores médios de três repetições \pm 0 erro padrão da média.

e.p. $=S / \sqrt{n} \quad S^{2}=\left(\Sigma X^{2}-(\Sigma X)^{2} / n\right) / n-1 \quad n=n .^{\circ}$ de repetições

Embora os valores de matéria seca a $25^{\circ} \mathrm{C}$, para cada período de incubação e concentração de enzima tenham sido diferentes, o efeito da enzima não foi significativo $(p>0,05)$, assim como o efeito da interação tempo $X$ enzima. Entretanto, $o$ efeito do tempo foi significativo $(p<0,05)$. Isto significa que os valores de matéria seca diminuíram em função do tempo para esta temperatura.

Os teores de matéria seca para os tratamentos a $25^{\circ} \mathrm{C}$ diferenciaram das demais temperaturas por terem apresentado uma elevação em relação a matéria-prima $(39,30 \mathrm{~g} / 100 \mathrm{~g})$ com 48 horas de incubação, nos tratamentos testemunha e com adição de $1 \mathrm{~mL}$ de enzima/Kg de raiz (Figura 15). Oyewole \& Odunfa (1988) observaram na produção de lafum um aumento do teor de umidade para $70,34 \%$ nas primeiras 36 horas, decrescendo em seguida gradualmente para valores próximos de $60 \%$. A perda durante o período final foi atribuída a osmose. 


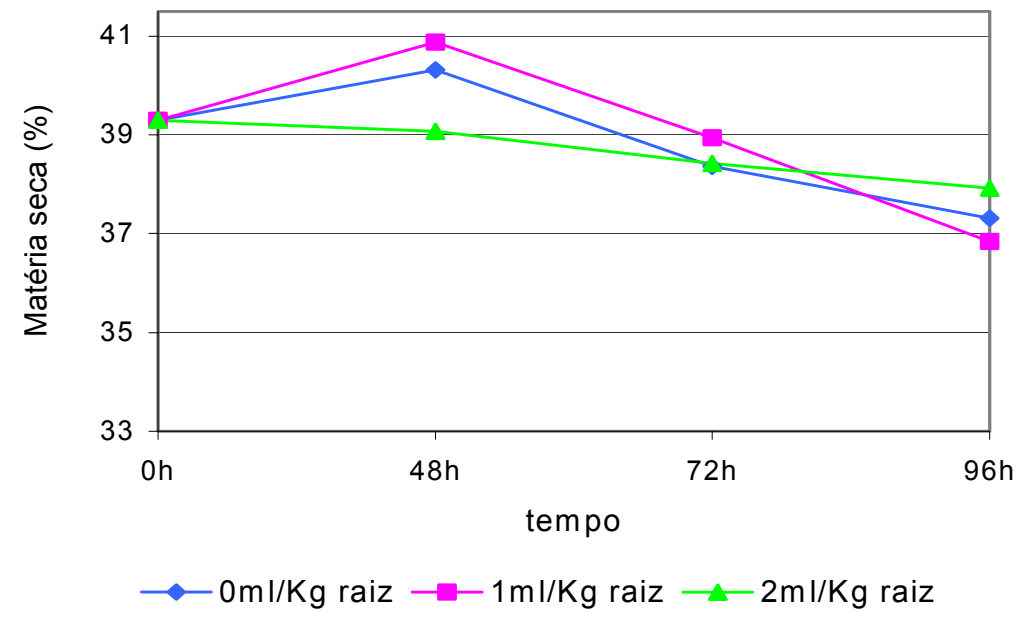

Figura 15 - Matéria seca das raízes fermentadas a $25^{\circ} \mathrm{C}$.

Já com 72 e 96 horas de fermentação os teores encontrados foram inferiores em relação a matéria-prima, para todos os tratamentos. Resultados semelhantes aos encontrados por Menezes et al. (1999), que observaram uma diminuição da matéria seca tanto nas pubas produzidas por fermentação natural quanto nas adicionadas de enzima.

$\mathrm{Na}$ temperatura de $30^{\circ} \mathrm{C}$ (Figura 16) no período entre 48 e 72 horas, o decréscimo dos teores de matéria seca não ocorreu de forma tão acentuada quanto a $25^{\circ} \mathrm{C}$ (Figura 15) e a $35^{\circ} \mathrm{C}$ (Figura 17). Esta estabilização após 48 horas de incubação, pode estar relacionada a temperatura $30^{\circ} \mathrm{C}$ ter apresentado características visuais de maceração completa neste período, provavelmente por ser considerada dentro da faixa de temperatura adequada para a fermentação.

Para as pubas fermentadas a 30 e $35^{\circ} \mathrm{C}$, o modelo de delineamento estatístico proposto não pôde explicar as alterações ocorridas nos valores de matéria seca. Nestes casos, os efeitos da enzima, do tempo e da interação tempo X enzima não foram significativos $(p>0,05)$, indicando que os resultados obtidos não foram influenciados pelo tempo, pela concentração de enzima, ou pela temperatura e sim por outros fatores não controlados no experimento. 
Tabela 6. Valores de matéria seca das raízes durante processo de fermentação a $30^{\circ} \mathrm{C}$.

\begin{tabular}{cccc}
\hline \multirow{2}{*}{ Tempo (h) } & \multicolumn{3}{c}{ Matéria seca (\%) \pm e.p.* } \\
\cline { 2 - 4 } & \multicolumn{3}{c}{ Concentração de enzima (mL/Kg de raiz) } \\
\cline { 2 - 4 } & $35,50 \pm 0,408$ & $35,76 \pm 2,012$ & $37,14 \pm 1,480$ \\
78 & $35,51 \pm 1,061$ & $36,08 \pm 0,867$ & $37,15 \pm 1,334$ \\
96 & $34,71 \pm 0,590$ & $36,91 \pm 2,952$ & $35,84 \pm 1,078$ \\
\hline
\end{tabular}

$\left(^{*}\right)$ Valores médios de três repetições \pm 0 erro padrão da média.

e.p. $=S / \sqrt{ } n \quad S^{2}=\left(\Sigma X^{2}-(\Sigma X)^{2} / n\right) / n-1 \quad n=n \cdot{ }^{\circ}$ de repetições

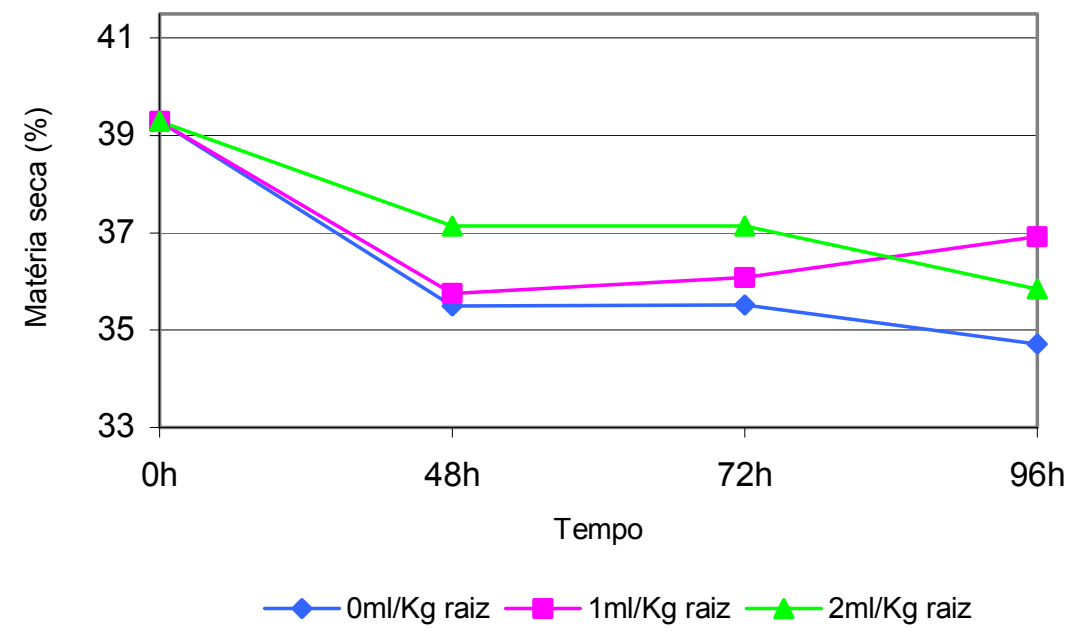

Figura 16 - Matéria seca das raízes fermentadas a $30^{\circ} \mathrm{C}$.

Nas temperaturas de 30 e $35^{\circ} \mathrm{C}$ os valores de matéria seca foram menores do que os obtidos a $25^{\circ} \mathrm{C}$, provavelmente devido a maceração mais acelerada e conseqüente lixiviação ocorrida nestas temperaturas. 
Tabela 7. Valores de matéria seca das raízes durante processo de fermentação a $35^{\circ} \mathrm{C}$.

\begin{tabular}{cccc}
\hline \multirow{2}{*}{ Tempo (h) } & \multicolumn{3}{c}{ Matéria seca (\%) \pm e.p.* } \\
\cline { 2 - 4 } & \multicolumn{3}{c}{ Concentração de enzima (mL/Kg de raiz) } \\
\cline { 2 - 4 } & $37,49 \pm 2,232$ & $36,49 \pm 2,054$ & $36,54 \pm 1,843$ \\
\hline 48 & $34,65 \pm 1,244$ & $34,86 \pm 1,403$ & $35,59 \pm 1,227$ \\
96 & $33,55 \pm 1,636$ & $34,86 \pm 1,243$ & $36,44 \pm 1,259$ \\
\hline
\end{tabular}

$\left(^{*}\right)$ Valores médios de três repetições \pm 0 erro padrão da média.

e.p. $=S / \sqrt{n} \quad S^{2}=\left(\Sigma X^{2}-(\Sigma X)^{2} / n\right) / n-1 \quad n=n .{ }^{0}$ de repetições

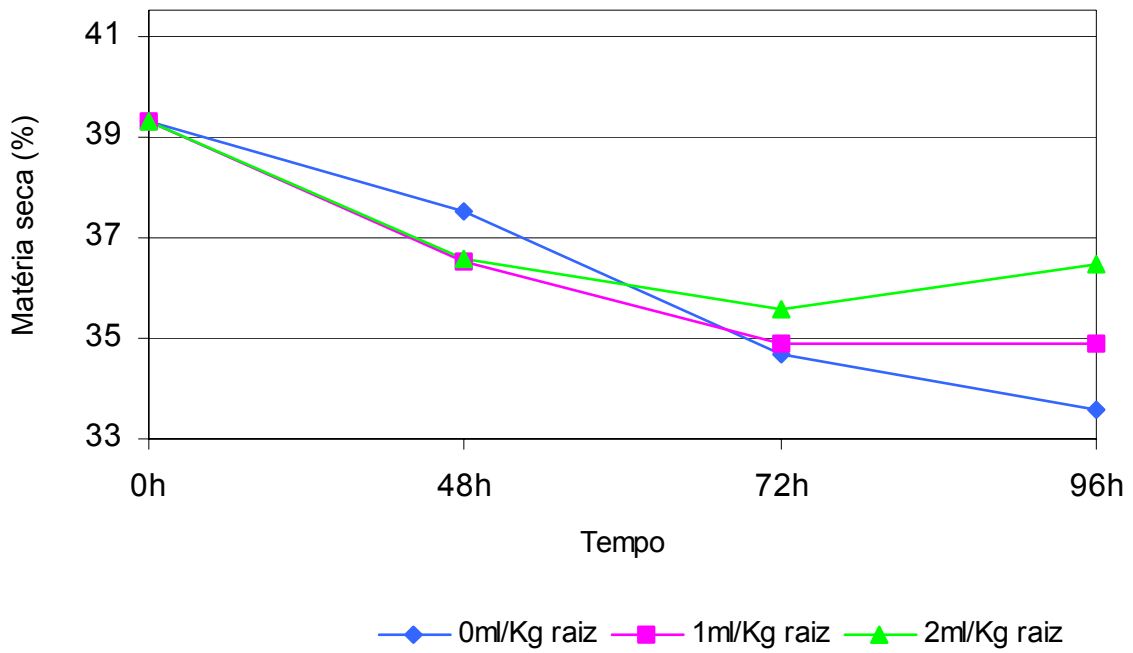

Figura 17 - Matéria seca das raízes fermentadas a $35^{\circ} \mathrm{C}$.

George et al. (1995) sugeriram que a embebição das raízes de mandioca em água, por períodos variados de tempo, poderiam acarretar alterações nos teores da matéria seca ao longo da fermentação. O decréscimo na matéria seca pode ser particularmente devido a redução nos conteúdos de açúcares e amido (consumidos pelo microrganismos ou lixiviados no líquido de fermentação). Também o amaciamento das raízes pode ser responsável pelo aumento da absorção de água contribuindo para redução da massa seca. 


\subsubsection{Valores de textura das raízes pubadas}

Os valores de textura das raízes pubadas foram obtidos após a retirada da água de fermentação. Este parâmetro avalia o grau de amolecimento dos tecidos durante a fermentação, indicando o grau de maceração do produto. Quanto menor o valor da textura maior o amolecimento do tecido e maior o grau de maceração.

Verificou-se que o decréscimo da textura foi mais acentuado nas primeiras 48 horas de fermentação em todos os tratamentos, já que todos os valores encontrados foram inferiores aos determinados na matéria-prima no início do processo $(18,62 \mathrm{lbf} / \mathrm{g})$. Este abrandamento acentuado ocorrido com 48 horas para todas as temperaturas, também foi observado nos experimentos de Oyewole (1990), Brauman et al. (1995) e Olivieri et al. (1999).

Tabela 8. Textura das raízes fermentadas a $25^{\circ} \mathrm{C}$.

\begin{tabular}{|c|c|c|c|}
\hline \multirow{3}{*}{ Tempo (h) } & \multicolumn{3}{|c|}{ Textura (lbf/g \pm e.p.*) } \\
\hline & \multicolumn{3}{|c|}{ Concentração de Enzima (mL/Kg de raiz) } \\
\hline & 0 & 1 & 2 \\
\hline 48 & $7,54 \pm 0,091^{\text {aA }}$ & $7,76 \pm 0,068^{\mathrm{aA}}$ & $6,52 \pm 0,159^{\mathrm{bA}}$ \\
\hline 72 & $3,81 \pm 0,044$ a & $3,92 \pm 0,038$ a B & $3,14 \pm 0,015^{b B}$ \\
\hline 96 & $3,43 \pm 0,035^{\text {ac }}$ & $3,41 \pm 0,044$ a c & $3,04 \pm 0,024$ \\
\hline
\end{tabular}

$\left(^{*}\right)$ Valores médios de três repetições \pm 0 erro padrão da média. Valores médios seguidos de letras minúsculas comparam médias dentro de cada tempo e, seguidos de letras maiúsculas comparam médias dentro de cada concentração de enzima, ao nível de $5 \%$ pelo teste de Tukey.

e.p. $=S / \sqrt{ } n \quad S^{2}=\left(\Sigma X^{2}-(\Sigma X)^{2} / n\right) / n-1 \quad n=n .^{\circ}$ de repetições

Nas fermentações a $25^{\circ} \mathrm{C}$, observou-se uma redução significativa dos valores de textura com o aumento do tempo de incubação para todos as concentrações de enzima (Tabela 8), principalmente até 48 horas onde valores de textura encontrados variaram de 7,76 a 6,52lbf/g. A diferença entre o início do processo e com 48 horas de incubação chegou a $12,10 \mathrm{lbf} / \mathrm{g}$ no tratamento adicionado de $2 \mathrm{~mL}$ de enzima/Kg de raiz. Com 72 horas, estes valores variaram de 3,92 a 3,14lbf/g representando uma diferença de 3,65lbf/g. Entre 72 e 96 horas a diferença foi bem menor, apenas 0,32lbf/g. Este 
comportamento demonstra que o maior abrandamento das raízes ocorreu até 48 horas, decrescendo lentamente até 72 horas e se estabilizando até 96 horas, coincidindo com o observado por Oyewole, (1990). A Figura 18 representa o comportamento os valores de textura a $25^{\circ} \mathrm{C}$.

No tratamento com $2 \mathrm{~mL}$ de enzima/Kg de raiz, pode-se observar uma redução entre 48 e 72 horas, seguida de estabilização até 96 horas, indicando que a puba adicionada de $2 \mathrm{~mL}$ de enzima/Kg com 72 horas já estava suficientemente fermentada e que o tratamento testemunha e o adicionado de $1 \mathrm{~mL}$ de enzima ainda continuaram a macerar até 96 horas (Tabela 8). Este comportamento demonstra a ação mais efetiva da concentração $2 \mathrm{~mL}$ de enzima/Kg de raiz nesta condição de temperatura no qual até mesmo os valores de rendimento diminuíram indicando fermentação excessiva resultando em menores rendimentos (Figura 21).

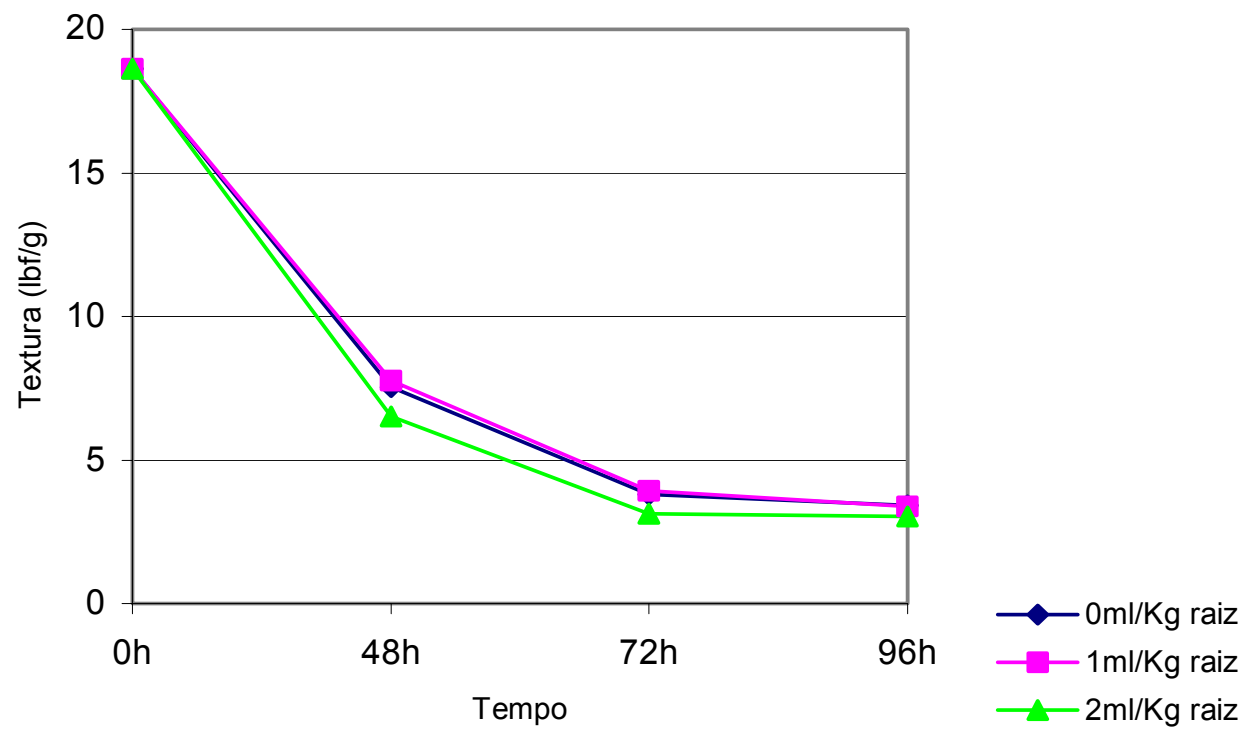

Figura 18 - Variações da textura das raízes ao longo da fermentação a $25^{\circ} \mathrm{C}$.

Para $30^{\circ} \mathrm{C}$ de temperatura, os valores de textura (Tabela 9) diminuíram mais rapidamente do que a $25^{\circ} \mathrm{C}$ para todos os tratamentos principalmente com 48 horas de incubação (Figura 19). 
Tabela 9. Textura das raízes fermentadas a $30^{\circ} \mathrm{C}$.

\begin{tabular}{|c|c|c|c|}
\hline \multirow{3}{*}{ Tempo (h) } & \multicolumn{3}{|c|}{ Textura (lbf/g \pm e.p.*) } \\
\hline & \multicolumn{3}{|c|}{ Concentração de Enzima (mL/Kg de raiz) } \\
\hline & 0 & 1 & 2 \\
\hline 48 & $3,60 \pm 0,044^{\text {a } A}$. & $3,18 \pm 0,031^{\mathrm{bA}}$ & $2,89 \pm 0,015^{\mathrm{cA}}$ \\
\hline 72 & $3,06 \pm 0,010^{a c}$ & $2,52 \pm 0,019^{b B}$ & $2,45 \pm 0,015^{b B}$ \\
\hline 96 & $3,29 \pm 0,021$ а в & $2,54 \pm 0,007^{\mathrm{bB}}$ & $2,49 \pm 0,006^{b B}$ \\
\hline
\end{tabular}

$\left(^{*}\right)$ Valores médios de três repetições \pm 0 erro padrão da média. Valores médios seguidos de letras minúsculas comparam médias dentro de cada tempo e, seguidos de letras maiúsculas comparam médias dentro de cada concentração de enzima, ao nível de $5 \%$ pelo teste de Tukey.

e.p. $=S / \sqrt{ } n \quad S^{2}=\left(\Sigma X^{2}-(\Sigma X)^{2} / n\right) / n-1 \quad n=n \cdot{ }^{\circ}$ de repetições

A diferença entre os valores encontrados com 48 horas de incubação, a temperatura de $25^{\circ} \mathrm{C}(7,54 \mathrm{lbf} / \mathrm{g})$ e a $30^{\circ} \mathrm{C}(3,6 \mathrm{lbf} / \mathrm{g})$ para o tratamento testemunha foi considerável, da ordem de 3,94lbf/g. Nos demais tratamentos a diferença na redução foi da mesma ordem ou maior dependendo do tratamento (Tabelas 8 e 9).

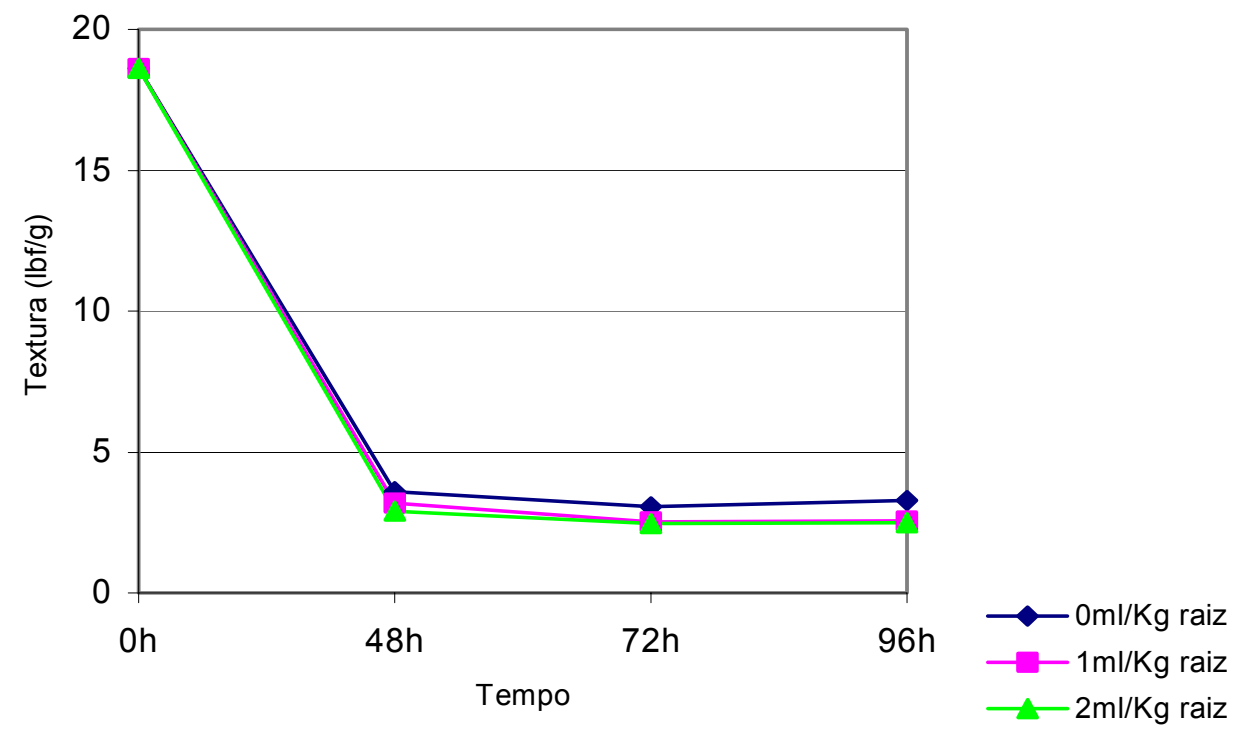

Figura 19 - Variações da textura das raízes ao longo da fermentação a $30^{\circ} \mathrm{C}$. 
Provavelmente os microrganismos se desenvolveram melhor a $30^{\circ} \mathrm{C}$ de temperatura, causando maceração mais intensa com conseqüente abrandamento da textura em menor tempo. A diferença entre o início do processo $(18,62 \mathrm{lbf} / \mathrm{g})$ e as texturas obtidas com 48 horas a $30^{\circ} \mathrm{C}$ foi da ordem de $15,30 \mathrm{lbf} / \mathrm{g}$. Esta diferença foi superior a encontrada neste intervalo de tempo para a temperatura de $25^{\circ} \mathrm{C}$, demonstrando maior degradação das células. Provocado pelo aumento da atividade de enzimas produzidas pelos microrganismos ou adicionadas ao processo.

Os valores médios de textura obtidas nas fermentações a $35^{\circ} \mathrm{C}$ estão representados na Tabela 10 e Figura 20. Para esta temperatura, a diminuição foi mais semelhante a ocorrida a $30^{\circ} \mathrm{C}$ (Figura 18) do que a $25^{\circ} \mathrm{C}$ (Figura 17) com valores de textura abaixo de $5 \mathrm{lbf} / \mathrm{g}$ com 48 horas de incubação.

Provavelmente, devido a heterogeneidade das raízes de mandioca, os valores de textura após 96 horas de fermentação foram significativamente superiores àqueles encontrados com 72 horas, como ocorreu na fermentação natural a $30^{\circ} \mathrm{C}$ (Tabela 9) e a $35^{\circ} \mathrm{C}$ (Tabela 10 ).

Tabela 10. Textura das raízes fermentadas a $35^{\circ} \mathrm{C}$.

\begin{tabular}{cccc}
\hline \multirow{2}{*}{ Tempo (h) } & \multicolumn{3}{c}{ Textura (lbf/g \pm e.p.*) } \\
\cline { 2 - 4 } & \multicolumn{3}{c}{ Concentração de Enzima (mL/Kg de raiz) } \\
\cline { 2 - 4 } & $4,73 \pm 0,019^{\text {a A }}$ & $2,91 \pm 0,032^{\mathrm{cA}}$ & $4,09 \pm 0,035^{\mathrm{bA}}$ \\
78 & $2,50 \pm 0,017^{\mathrm{bc}}$ & $2,41 \pm 0,042^{\mathrm{b} \mathrm{B}}$ & $3,12 \pm 0,012^{\text {a } \mathrm{B}}$ \\
96 & $2,75 \pm 0,019^{\text {а в }}$ & $2,47 \pm 0,019^{\mathrm{b} \mathrm{B}}$ & $2,35 \pm 0,012^{\mathrm{bc}}$ \\
\hline
\end{tabular}

(*) Valores médios de três repetições \pm 0 erro padrão da média. Valores médios seguidos de letras minúsculas comparam médias dentro de cada tempo e, seguidos de letras maiúsculas comparam médias dentro de cada concentração de enzima, ao nível de $5 \%$ pelo teste de Tukey.

e.p. $=S / \sqrt{ } n \quad S^{2}=\left(\Sigma X^{2}-(\Sigma X)^{2} / n\right) / n-1 \quad n=n \cdot{ }^{0}$ de repetições 


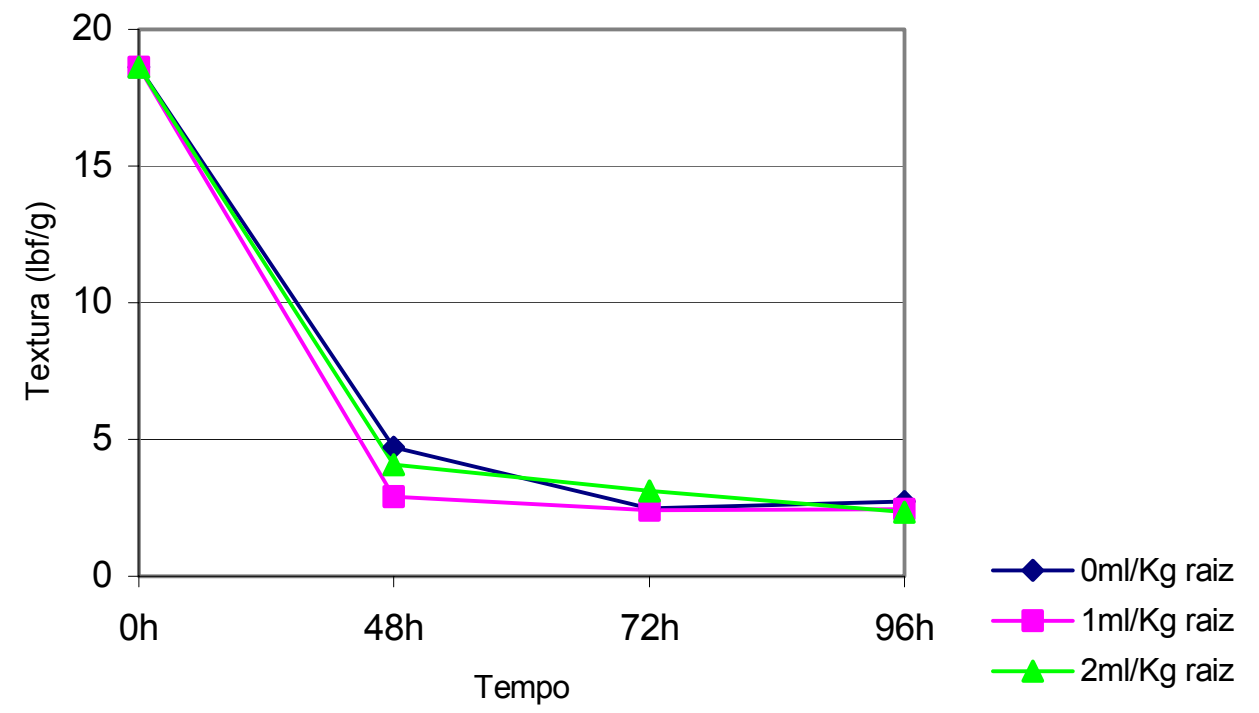

Figura 20 - Variações da textura das raízes ao longo da fermentação a $35^{\circ} \mathrm{C}$.

Conforme esperado (Olivieri et al., 1999; Brauman et al., 1995; Nanda \& George, 1996) houve redução nos valores de texturas, o que pode ser explicado pela ação de enzimas presentes na fermentação natural e adicionadas ao processo, que tiveram sua intensidade de ação maior ou menor dependendo das condições.

Os resultados da análise estatística e valores de $\mathrm{F}$ das fermentações a 25, 30 e $35^{\circ} \mathrm{C}$ estão apresentados na Tabela 11.

Tabela 11. Análise estatística dos valores de textura

\begin{tabular}{llll}
\hline \multicolumn{1}{c}{ Causas de variação } & \multicolumn{3}{c}{ Valores de $\mathrm{F}$} \\
\hline Temperatura & $25^{\circ} \mathrm{C}$ & $30^{\circ} \mathrm{C}$ & $35^{\circ} \mathrm{C}$ \\
\hline Tempo & $2913,53^{* *}$ & $542,86^{* *}$ & $2499,04 * *$ \\
Concentração de enzima & $112,27^{* *}$ & $892,02^{* *}$ & $648,82^{* *}$ \\
Tempo $\times$ Concentração de enzima & $10,00 * *$ & $18,83 * *$ & $426,80 * *$ \\
\hline ** significativo ao nível de $1 \%$ & Coeficiente de & Coeficiente de & Coeficiente de \\
$*$ significativo ao nível de 5\% & variação: 2,596 & variação: 1,298 & variação: 1,505 \\
n.s.: não significativo ao nível de 5\% & & &
\end{tabular}


$\mathrm{Na}$ análise de variância pode-se observar que, os valores de textura obtidos demonstraram efeito significativo $(p<0,05)$ tanto para variável enzima como para a variável tempo, assim como, para interação tempo $X$ enzima. Este resultado coincidiu para todas as temperaturas (Tabela 11) indicando que o abrandamento da textura sofreu a influência de todos os tratamentos isoladamente, além da influência que um fator (tempo) tem sobre a ação do outro (concentração de enzima), o que justificaria o ocorrido de um grau de maceração maior dos tecidos expostos a ação da enzima por períodos prolongados de tempo.

\subsubsection{Rendimento}

Uma das formas de se avaliar o desempenho de um processo industrial é o rendimento e qualidade do produto final. $O$ rendimento, no presente trabalho foi expresso pelo quociente entre a massa seca de puba obtida e a massa seca das raízes processadas.

De forma geral, os rendimentos para cada temperatura foram distintos e específicos para cada condição de tempo e concentração de enzima, não tendendo a seguir um comportamento padrão de variação.

Para temperatura de $25^{\circ} \mathrm{C}$ a Figura 21 mostra o rendimento em função da concentração de enzima, onde o rendimento mais elevado foi $76,96 \%$ obtido na concentração $1 \mathrm{~mL}$ de enzima/Kg de raiz com 72 horas de fermentação (Tabela 12). Entretanto, este resultado não diferiu significativamente dos rendimentos da fermentação natural $(74,74 \%)$ e daquele com adição de $2 \mathrm{~mL}$ de enzima/Kg de raiz (73,63\%). Os rendimentos mais baixos foram obtidos no período de 96 horas, com valor médio de $71,95 \%$ em todos os tratamentos, e o menor valor foi obtido na fermentação natural $(69,78 \%)$. A adição de $1 \mathrm{~mL}$ de enzima parece favorecer o processo nesta temperatura para todos os tempos testados.

A Figura 22 mostra os rendimentos obtidos a $25^{\circ} \mathrm{C}$ em função do tempo. As perdas ocorridas nos tratamentos submetidos a 48 horas de fermentação, provavelmente ocorreram em função da quantidade de partes não pubadas retiradas na limpeza (Figura 8), principalmente no tratamento testemunha. 
Tabela 12. Valores de rendimento do processo de fermentação a $25^{\circ} \mathrm{C}$.

\begin{tabular}{ccccc}
\hline \multirow{2}{*}{ Tempo (h) } & \multicolumn{4}{c}{ Rendimento (\% \pm e.p.) $)^{*}$} \\
\cline { 2 - 5 } & 0 & 1 & 2 & Média \\
\hline 48 & $70,71 \pm 0,521$ & $75,03 \pm 0,439$ & $72,21 \pm 0,418$ & $72,65^{\mathrm{b}}$ \\
72 & $74,74 \pm 0,132$ & $76,96 \pm 1,060$ & $73,63 \pm 0,295$ & $75,11^{\text {a }}$ \\
96 & $69,78 \pm 0,490$ & $74,13 \pm 0,436$ & $71,94 \pm 0,521$ & $71,95^{\mathrm{b}}$ \\
Média & $71,74^{\mathrm{B}}$ & $75,37^{\mathrm{A}}$ & $72,60^{\mathrm{B}}$ \\
\hline
\end{tabular}

$\left(^{*}\right)$ Valores médios de três repetições \pm 0 erro padrão da média. Valores médios seguidos de letras minúsculas comparam médias dentro de cada tempo e, seguidos de letras maiúsculas comparam médias dentro de cada concentração de enzima, ao nível de $5 \%$ pelo teste de Tukey.

e.p. $=S / \sqrt{n} \quad S^{2}=\left(\Sigma X^{2}-(\Sigma X)^{2} / n\right) / n-1 \quad n=n \cdot{ }^{\circ}$ de repetições

Esta condição de fermentação a $25^{\circ} \mathrm{C}$, não pareceu ser a mais adequada para que a microbiota responsável pelo processo, se desenvolvesse e produzisse enzimas suficientes para macerar as raízes, conforme indicam os rendimentos significativamente inferiores na fermentação natural quando comparado com o tratamento com $1 \mathrm{~mL}$ de enzima/Kg de raízes (Tabela 12).

De forma semelhante, Menezes et al. (1999) observaram rendimentos médios $(42,4 \%)$ superiores nas pubas produzidas a temperatura ambiente com adição do $1,5 \mathrm{~g}$ de pectinase $/ \mathrm{Kg}$ de raiz do que as obtidas de fermentação natural $(39,3 \%)$, embora os valores de rendimento deste estudo tenham sido superiores aos relatados pelos autores.

Almeida (1992) observou que, em experimentos conduzidos a temperaturas de 24 a $26^{\circ} \mathrm{C}$ a fermentação só ocorreu após 144 horas de incubação. Este mesmo autor afirma que a $40^{\circ} \mathrm{C}$ não ocorreu fermentação típica, mesmo após o período de 96 horas, indicando como ideal temperaturas entre 28 e $32^{\circ} \mathrm{C}$, apesar de ter observado uma baixa velocidade de fermentação (60-72 horas). 


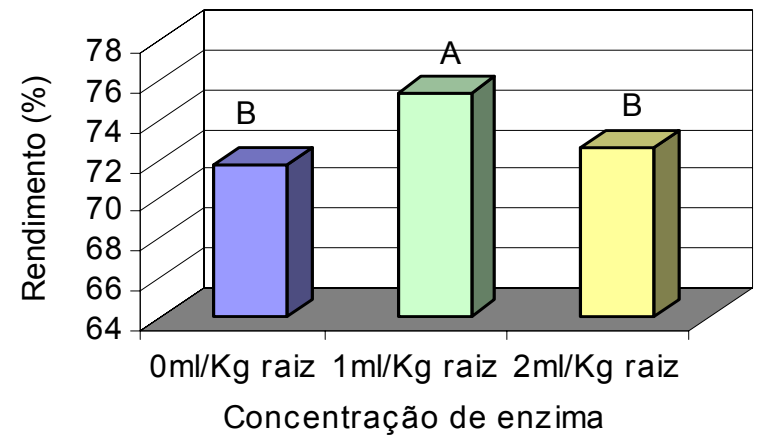

Figura 21 - Rendimento em função da concentração de enzima da fermentação a $25^{\circ} \mathrm{C}$. Valores médios de rendimento seguidos de letras maiúsculas comparam médias de rendimento dentro de cada concentração de enzima, ao nível de $5 \%$ pelo teste de Tukey.

Já com 72 horas na temperatura de $25^{\circ} \mathrm{C}$ não só o rendimento da fermentação natural aumentou, mas o rendimento de todos os tratamentos aumentaram. Na fermentação natural o acréscimo chegou a 4,03\%, provavelmente pelo estado mais adiantado da maceração após este período e a menor eliminação de partes não pubadas na limpeza

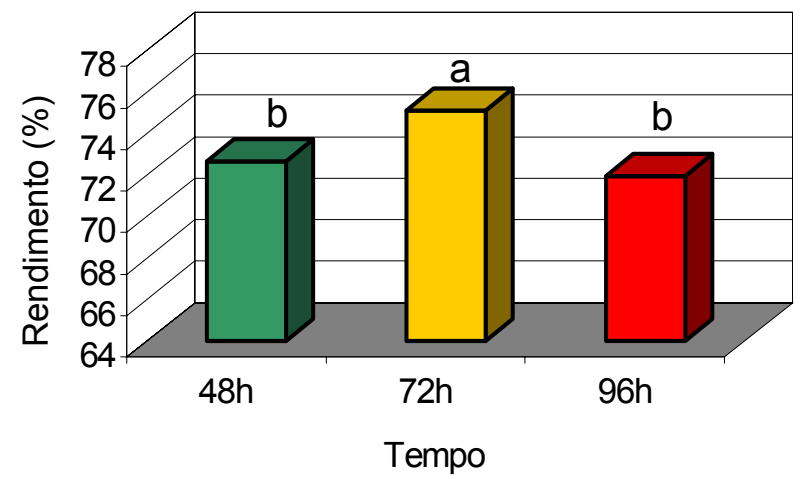

Figura 22 - Rendimento em função do tempo de fermentação a $25^{\circ} \mathrm{C}$.

Valores médios de rendimento seguidos de letras minúsculas comparam médias de rendimento dentro de cada tempo, ao nível de $5 \%$ pelo teste de Tukey. 
No experimento realizado a $25^{\circ} \mathrm{C}$, os tratamentos adicionados de $1 \mathrm{~mL} / \mathrm{Kg}$ de raiz apresentaram rendimento significativamente superior para todos os tempos. Entretanto, quando a concentração de enzima foi $2 \mathrm{~mL} / \mathrm{Kg}$ de raiz, o rendimento tornouse significativamente inferior ao de $1 \mathrm{~mL}$, não diferindo do rendimento obtido na fermentação natural. Analisando estes resultados, observa-se mas uma vez que $1 \mathrm{~mL}$ de enzima/Kg de raiz acelerou o processo fermentativo, que era lento devido a baixa temperatura, mas quando a concentração de enzima foi aumentada para $2 \mathrm{~mL} / \mathrm{Kg}$ de raiz ocorreram menores rendimentos.

Os resultados apresentados na Tabela 13 mostram que 0 rendimento mais elevado nas fermentações a $30^{\circ} \mathrm{C}$ foi $74,71 \%$ com 48 horas de incubação e $2 \mathrm{~mL}$ de enzima/Kg de raiz. Entretanto esse rendimento não diferiu significativamente daqueles obtidos no mesmo período paro os tratamentos com $1 \mathrm{~mL}$ de enzima/Kg de raiz e da fermentação natural (Figura 23).

Tabela 13. Valores de rendimento do processo de fermentação a $30^{\circ} \mathrm{C}$.

\begin{tabular}{cccc}
\hline \multirow{2}{*}{ Tempo (h) } & \multicolumn{3}{c}{ Rendimento (\% \pm e.p.)* } \\
\cline { 2 - 4 } & \multicolumn{3}{c}{ Concentração de enzima (mL/Kg de raiz) } \\
\cline { 2 - 4 } & 0 & 1 & 2 \\
\hline 48 & $74,38 \pm 0,147^{\text {a A }}$ & $74,43 \pm 0,384^{\text {a A }}$ & $74,71 \pm 0,293^{\text {a A }}$ \\
72 & $67,89 \pm 0,414^{\text {b в }}$ & $71,84 \pm 0,497^{\text {a }}$ & $66,66 \pm 0,294^{\text {b }}$ \\
96 & $68,41 \pm 0,514^{\text {a в }}$ & $68,81 \pm 0,563^{\text {a }}$ & $59,17 \pm 0,452^{\text {b }}$ \\
\hline
\end{tabular}

(*) Valores médios de três repetições \pm 0 erro padrão da média. Valores médios Seguidos de letras minúsculas comparam médias dentro de cada tempo e, seguidos de letras maiúsculas comparam médias dentro de cada concentração de enzima, ao nível de $5 \%$ pelo teste de Tukey.

e.p. $=S / \sqrt{n} \quad S^{2}=\left(\Sigma X^{2}-(\Sigma X)^{2} / n\right) / n-1 \quad n=n .{ }^{0}$ de repetições

O fato dos rendimentos obtidos nos tratamentos incubados por 48 horas a $30^{\circ} \mathrm{C}$ terem sido iguais para todas as concentrações de enzima pode indicar que a presença de enzima não incrementou o processo fermentativo. Este resultado pode ter ocorrido devido a velocidade de fermentação natural a $30^{\circ} \mathrm{C}$ (Figura 23) ter sido máxima e, mesmo adicionando enzima em qualquer concentração, esta não acelerou o processo ou provocou alterações de rendimento. O mesmo comportamento não foi 
verificado para os demais períodos, durante os quais além de apresentarem valores menores de rendimento, também apresentou variações em função do tempo e do aumento da concentração de enzima.

Os valores de rendimento obtidos a $30^{\circ} \mathrm{C}$ nos períodos superiores a 48 horas de incubação foram menores, indicando que 48 horas é o período de incubação que proporciona maiores rendimentos nesta temperatura, podendo encerrar o processo (Figura 23).

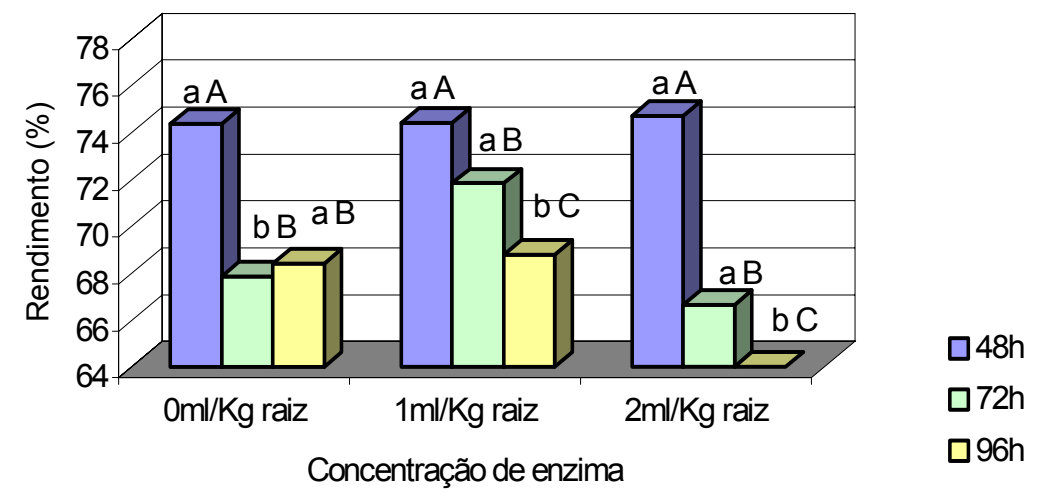

Figura 23 - Rendimento do processo de fermentação a $30^{\circ} \mathrm{C}$.

Valores Médios seguidos de letras minúsculas comparam médias de rendimento dentro de cada tempo e, seguidos de letras maiúsculas comparam médias de rendimento dentro de cada concentração de enzima, ao nível de $5 \%$ pelo teste de Tukey.

$\mathrm{Na}$ temperatura de $35^{\circ} \mathrm{C}$, o rendimento mais elevado foi $75,66 \%$ (Tabela 14), obtido na fermentação natural com 72 horas. Entretanto, esse rendimento não diferiu significativamente daqueles obtidos nos tratamentos adicionados de enzima. Maiores rendimentos ocorreram neste período.

Os menores rendimentos ocorreram com $2 \mathrm{~mL}$ de enzima tanto a $30^{\circ} \mathrm{C}$ (Tabela 13) quanto a $35^{\circ} \mathrm{C}$ (Tabela 14). Olivieri et al. (1999) observaram maiores rendimentos nos tratamentos adicionados de enzima.

Provavelmente as perdas ocorreram pelo excesso de maceração dos tecidos que resulta em aumento de turvidez (Figura 11), tanto no líquido drenado da fermentação quanto na água de lavagem (Figura 6), pela lixiviação de material (constituintes das raízes de mandioca macerada que se perdem para o líquido de fermentação). 
Embora esta lixiviação tenha ocorrido em todos os tratamentos, foi maior ou menor dependendo do estádio de fermentação. As raízes em estádios mais adiantadas, seja pelo efeito do tempo, da adição de enzima ou da temperatura, possuem uma disponibilidade maior de constituintes a serem lixiviados que aquelas em estágios iniciais de fermentação, acarretando assim maiores ou menores rendimentos.

Tabela 14. Valores de rendimento do processo de fermentação a $35^{\circ} \mathrm{C}$.

\begin{tabular}{cccc}
\hline \multirow{2}{*}{ Tempo (h) } & \multicolumn{3}{c}{ Rendimento (\% \pm e.p.)* } \\
\cline { 2 - 4 } & \multicolumn{3}{c}{ Concentração de enzima (mL/Kg de raiz) } \\
\cline { 2 - 4 } & $71,88 \pm 0,514^{\text {a B }}$ & $72,77 \pm 0,442^{\text {a B }}$ & $73,33 \pm 0,354^{\text {a A }}$ \\
78 & $75,66 \pm 0,249^{\text {a A }}$ & $74,11 \pm 0,413^{\text {a AB }}$ & $74,58 \pm 0,407^{\text {a A }}$ \\
96 & $71,69 \pm 0,521^{\text {b в }}$ & $75,54 \pm 0,489^{\text {a A }}$ & $69,73 \pm 0,262^{\text {b }}$ \\
\hline
\end{tabular}

$\left(^{*}\right)$ Valores médios de três repetições \pm 0 erro padrão da média. Valores médios Seguidos de letras minúsculas comparam médias dentro de cada tempo e, seguidos de letras maiúsculas comparam médias dentro de cada concentração de enzima, ao nível de $5 \%$ pelo teste de Tukey.
e.p. $=S / \sqrt{ } n$
$S^{2}=\left(\Sigma X^{2}-(\Sigma X)^{2} / n\right) / n-1$
$\mathrm{n}=\mathrm{n} \cdot{ }^{\circ}$ de repetições

A Figura 24 apresenta os valores de rendimento final da puba obtida por fermentação a $35^{\circ} \mathrm{C}$.

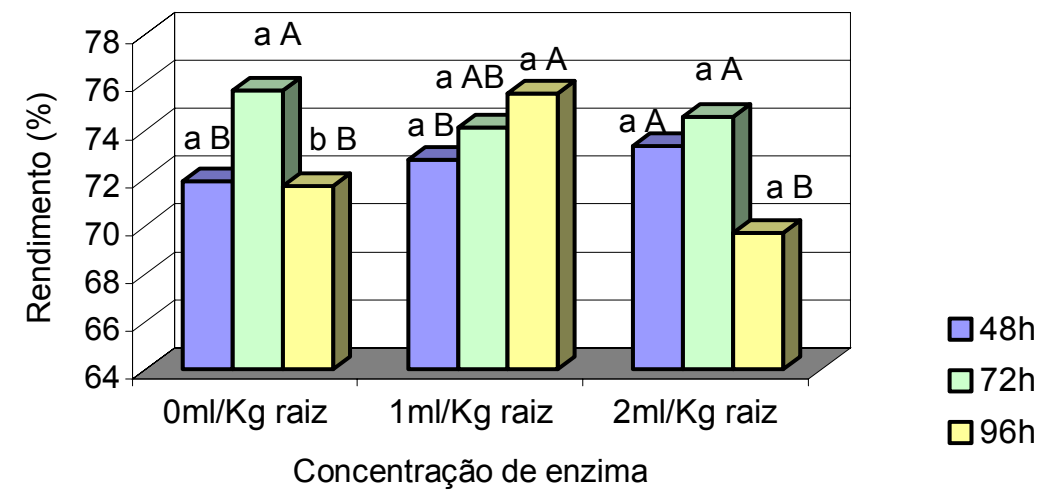

Figura 24 - Rendimento do processo de fermentação a $35^{\circ} \mathrm{C}$.

Valores Médios seguidos de letras minúsculas comparam médias de rendimento dentro de cada tempo e, seguidos de letras maiúsculas comparam médias de rendimento dentro de cada concentração de enzima, ao nível de $5 \%$ pelo teste de Tukey. 
Pode-se constatar que, para todas as temperaturas, os menores rendimentos geralmente foram obtidos nos períodos mais longos de incubação (96 horas) e maior concentração de enzima ( $2 \mathrm{~mL} / \mathrm{Kg}$ de raiz). Isto indica que, durante a fermentação há um determinado período, no qual o rendimento é máximo, ocorrendo consequentemente perdas mínimas. Ou seja, mesmo incubando-se em temperatura ótima, períodos prolongados de incubação levam a maiores perdas por excesso de consumo do substrato pelos microrganismos. Por outro lado períodos muito curtos levam a perdas, devido as partes não pubadas das raízes, que serão removidas posteriormente no processo de limpeza da puba.

Os resultados da análise estatística e valores de $\mathrm{F}$ para rendimento final de todas as temperaturas estão apresentados na Tabela 15.

$\mathrm{Na}$ análise de variância para a temperatura $25^{\circ} \mathrm{C}$, o efeito da enzima foi significativo $(p<0,05)$, assim como o efeito do tempo. Entretanto, o efeito da interação tempo $X$ enzima não foi significativo $(p>0,05)$. Isto significa que a ação da enzima não foi influenciada pelo tempo de fermentação. Na fermentação a $25^{\circ} \mathrm{C}$, a interação não significativa pode estar associada ao fato desta não ser a temperatura mais indicada para atividade máxima da enzima.

Tabela 15. Análise estatística dos valores de rendimento.

\begin{tabular}{llll}
\hline \multicolumn{2}{c}{ Causas de variação } & \multicolumn{3}{l}{ Valores de $\mathrm{F}$} \\
\hline Temperatura & $25^{\circ} \mathrm{C}$ & $30^{\circ} \mathrm{C}$ & $35^{\circ} \mathrm{C}$ \\
\hline Tempo & $28,80^{* *}$ & $365,58^{* *}$ & $30,82^{* *}$ \\
Concentração de enzima & $37,80^{* *}$ & $108,02^{* *}$ & $11,40^{* *}$ \\
Tempo $\times$ Concentração de enzima & $2,80^{\text {n.s. }}$ & $54,02 * *$ & $22,82 * *$ \\
\hline ** significativo ao nível de $1 \%$ & Coeficiente de & Coeficiente de & Coeficiente de \\
* significativo ao nível de $5 \%^{\text {n.s.: não significativo ao nível de } 5 \%}$ & variação: 1,263 & variação: 1,768 & variação: 1,768
\end{tabular}

Já para as temperaturas de 30 e $35^{\circ} \mathrm{C}$ pode-se observar o efeito significativo $(p<0,05)$ tanto para variável enzima, como tempo, assim como para interação tempo X enzima. 


\subsubsection{Rendimento $\times$ textura}

Tendo como objetivo associar textura das raízes e rendimento máximo do processo com a determinação de um ponto final de fermentação, foi realizado um estudo de correlação e regressão linear entre estas duas variáveis.

O estudo de correlação demonstrou que houve indícios de associação entre os dados de rendimento e os de textura para os experimentos realizados a $30^{\circ} \mathrm{C}$ (Figura 25-a). O coeficiente de correlação indicou uma associação da ordem de $53,51 \%$, significando que a mesma é verdadeira quando se exige uma probabilidade de erro inferior a $5 \%$ para tomar esta decisão.

A análise de variância da regressão (valor de $\mathrm{F}=10,03^{*}$ ) conduziu à mesma conclusão da análise de correlação, indicando que há indícios para se afirmar que exista efeito significativo do modelo, que procure explicar a variação do rendimento em função da textura, mesmo com o valor de $* * \mathrm{R}^{2}=28,64 \%$, significando o ajuste baixo do modelo na variação dos dados e que grande parte da variação não é atribuída ao modelo. O rendimento e textura não foram fatores controlados neste estudo e sim resposta (variáveis dependentes) das condições oferecidas por outros fatores fixos, fato que pode levar a este baixo ajuste do modelo.

Já para as temperaturas de 25 e $35^{\circ} \mathrm{C}$ o estudo de correlação não mostrou indícios de que a variação do rendimento esteja associado a textura (Figuras 25-a e 25-c). O coeficiente de correlação indicou associação da ordem de -8,3 e $19,62 \%$ para 25 e $35^{\circ} \mathrm{C}$ respectivamente, entretanto, um teste estatístico não oferece indícios de que a associação verdadeira seja significativa quando se exige uma probabilidade de erro inferior a $5 \%$ para tomar esta decisão.

A existência de associação, Figura 25-b mostra que a variação da textura se associa a mudanças nos valores de rendimento final. Já nas Figuras 25-a e 25-c, não houve associação. Mudando-se a textura, por exemplo, de 2,5 para 5,5lbf/g, não se obtém mudanças significativas nos rendimentos, representados no eixo y das figuras. Este comportamento pode ser observado principalmente nas temperaturas de 25 e $35^{\circ} \mathrm{C}$. 


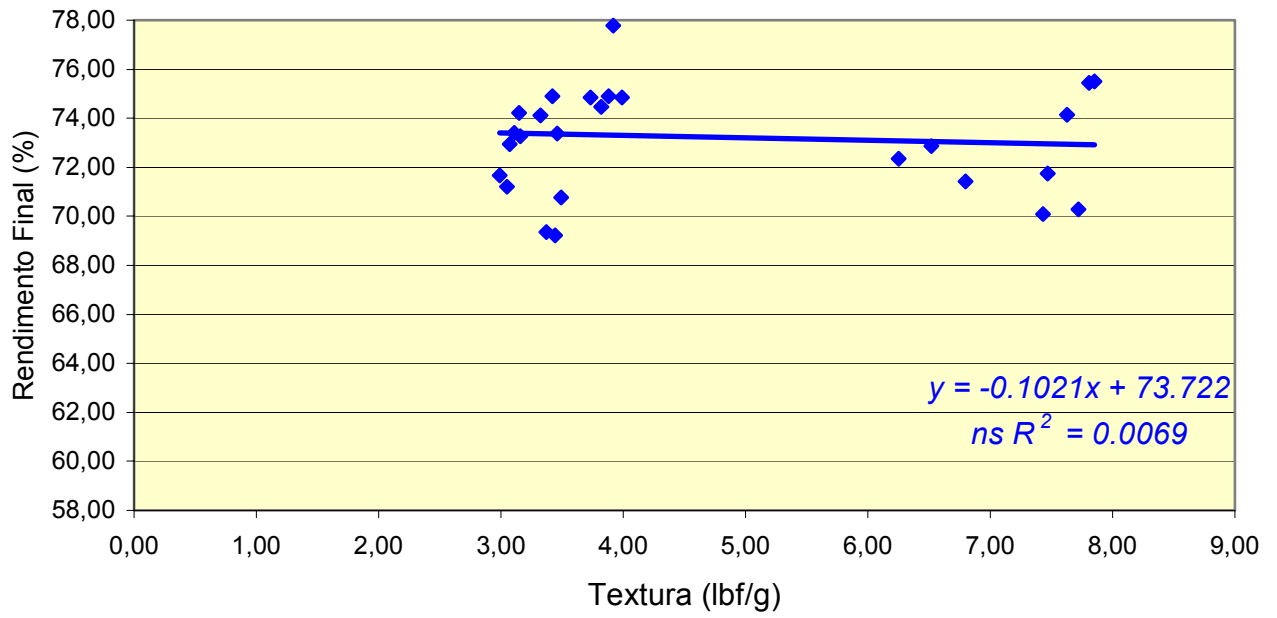

(Figura a)

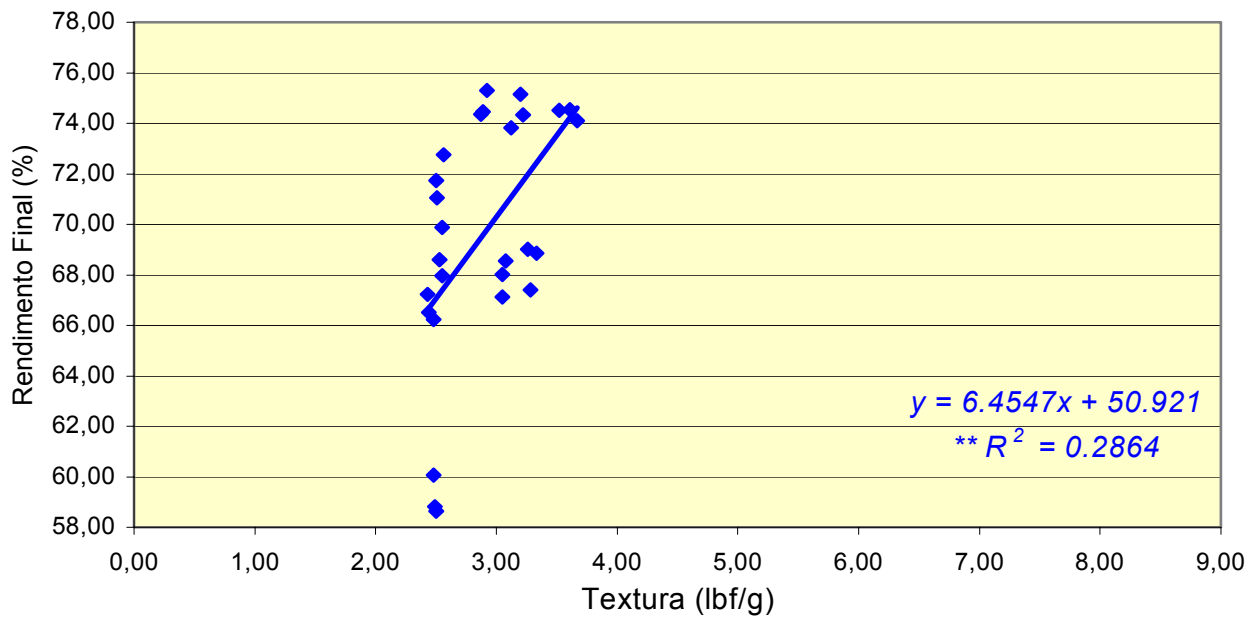

(Figura b)

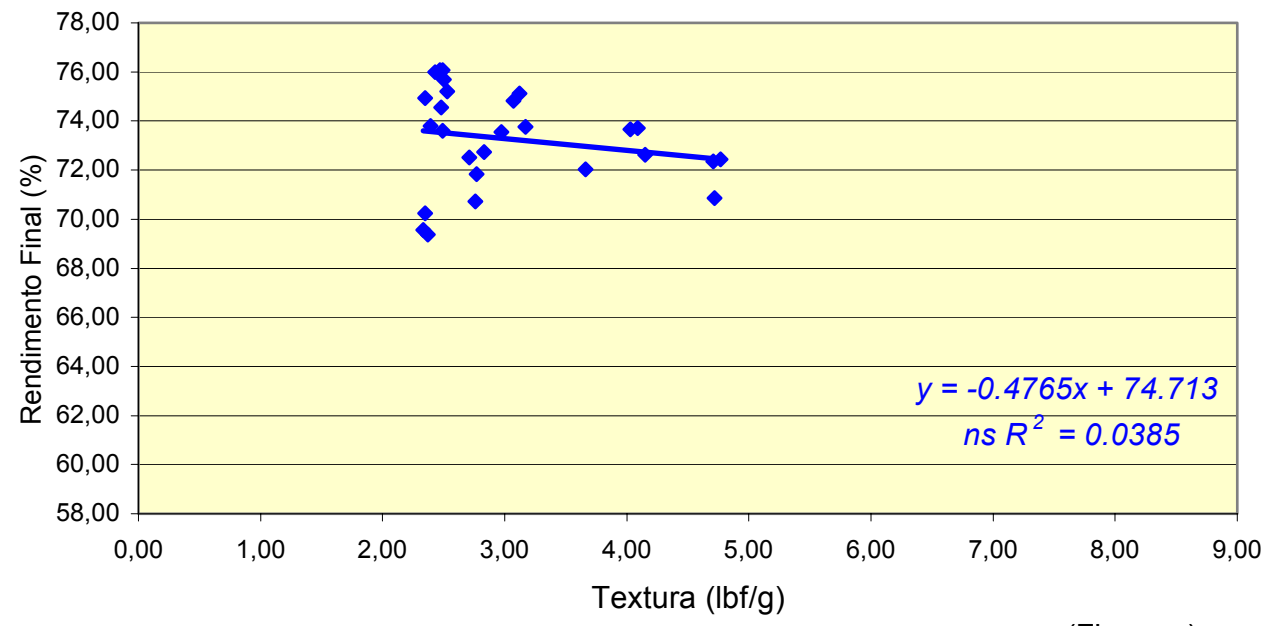

(Figura c)

Figura 25 - Regressão entre rendimento e textura nas temperaturas de $25^{\circ} \mathrm{C}$ (Figura a); $30^{\circ} \mathrm{C}$ (Figura b) e $35^{\circ} \mathrm{C}$ (Figura c). 
O fato de não ter sido determinada a associação entre textura e rendimento para as temperaturas de 25 e $35^{\circ} \mathrm{C}$ não significa que elas não existam. Significa que para os dados obtidos nessas condições experimentais, o estudo não foi conclusivo para evidenciar a associação entre as variáveis textura e rendimento. Outras condições experimentais, poderiam conduzir a conclusões diferentes das atuais.

No entanto, observando as Tabelas 12, 13 e 14 verifica-se que o maior rendimento ocorreu com 72 horas de incubação nas temperaturas de 25 e $35^{\circ} \mathrm{C}$ e 48 horas na temperatura de $30^{\circ} \mathrm{C}$. O intervalo de textura observado a $25^{\circ} \mathrm{C}$ com 72 horas foi entre 3,11 e 3,99lbf/g (Tabela 8); para $30^{\circ} \mathrm{C}$ entre 2,87 e 3,87lbf/g (Tabela 9), e para $35^{\circ} \mathrm{C}$ o intervalo foi entre 2,35 e 4,00lbf/g (Tabela 10). Assim, o intervalo da textura entre 2,35 e $4,00 \mathrm{lbf} / \mathrm{g}$, foi aquele que proporcionou os maiores rendimentos.

Foi realizado também o desdobramento no tempo (Figura 26), encontrando-se resultados significativos de regressão para os períodos de 48 horas (ao nível de $10 \%$ com $R^{2}=12,77 \%$ ) de 72 horas (ao nível de $5 \%$ com $* R^{2}=17,81 \%$ ), observado nas Figuras 26-a e 26-b, respectivamente.

O período de 72 horas, apresentou valores de textura de 3,92 e $3,86 \mathrm{lbf} / \mathrm{g}$ e rendimentos de $77,78 \%$ e $78,25 \%$ para a primeira e segunda repetições do experimento a $25^{\circ} \mathrm{C}$ por 72 horas (Anexo A). Se considerarmos a equação da Figura 26-b, mesmo com valor de $\mathrm{R}^{2}$ baixo, para fazermos uma estimativa e substituirmos $\mathrm{ox}$ por $3 \mathrm{lbf} / \mathrm{g}$ teríamos um rendimento de $72,91 \%$, mas se substituirmos por $4 \mathrm{lbf} / \mathrm{g}$ teremos um rendimento melhor de $75,51 \%$, indicando que valores de textura próximos a $4 \mathrm{lbf} / \mathrm{g}$ seriam suficiente para interromper o processo, para as condições testadas, sem causar maiores perdas ao processo.

Já o período de 96 horas de incubação, não apresentou indícios para se afirmar que haja efeito significativo do modelo que procure explicar a variação do rendimento em função da textura, pois os resultados não foram significativos (Figura 26-c).

Assim, pode-se propor que valores de textura próximos a 4lbf/g possam ser considerados parâmetro para finalizar a fermentação. 


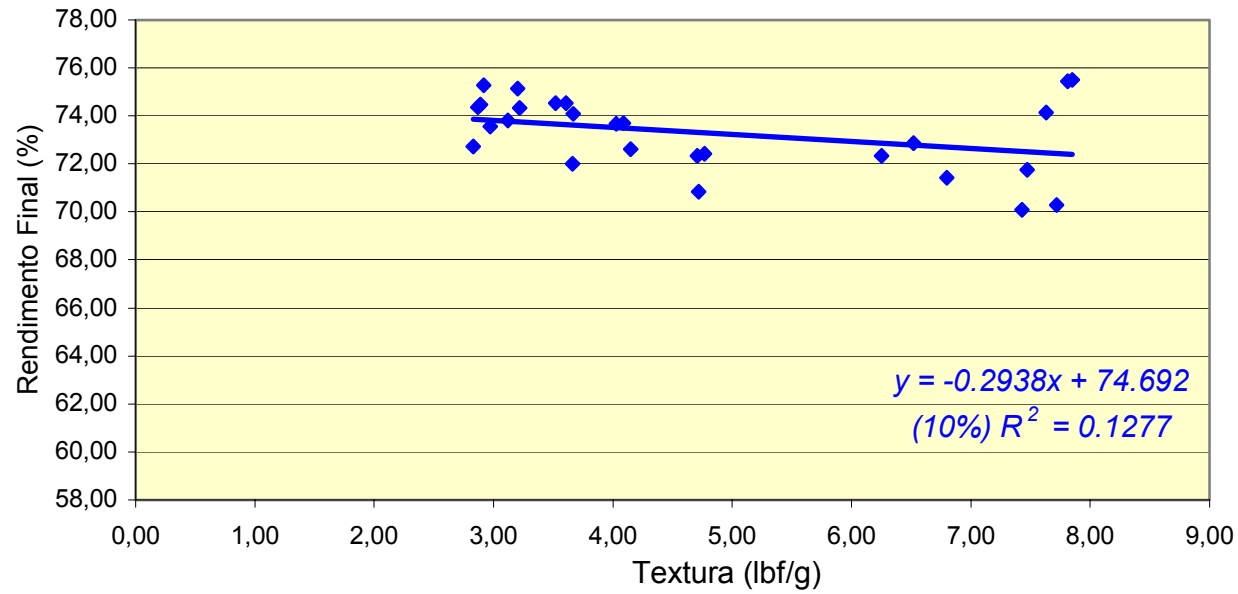

(Figura a)

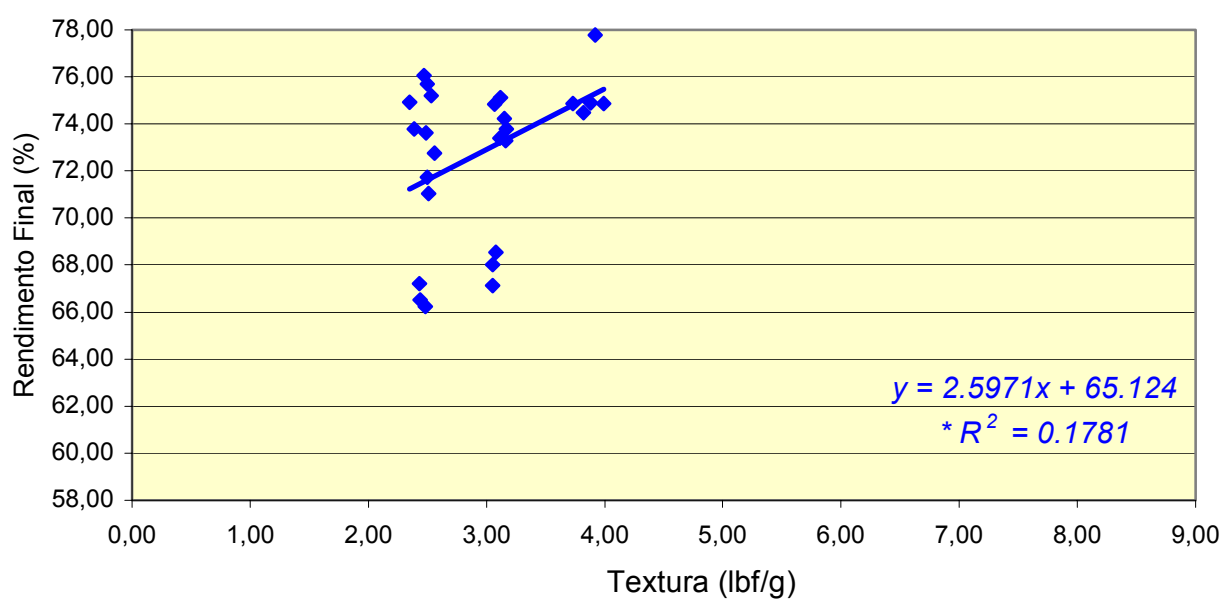

(Figura b)

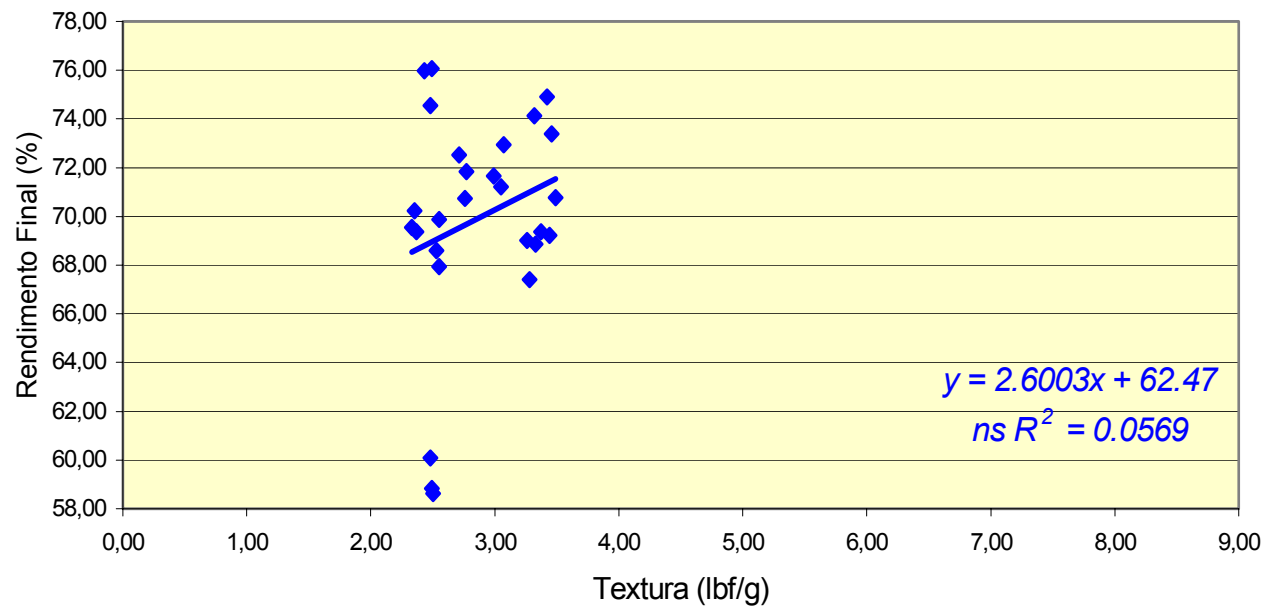

(Figura c)

Figura 26 - Regressão entre rendimento e textura nos períodos de 48 horas (Figura a); 72 horas (Figura b) e 96 horas (Figura c). 
Sugere-se estudos mais minuciosos, incluindo menores períodos de incubação e o estabelecimento de valores fixos de textura como variável preditora (independente), para o esclarecimento mais profundo da relação entre o rendimento e a textura.

\subsection{Propriedades físico-químicas das amostras de farinha de puba}

O processo fermentativo ocasiona profundas modificações nas características físico-químicas, organolépticas e funcionais da matéria-prima. A produção de puba não é uma exceção. Procurou-se neste trabalho relacionar a influência dos tratamentos nas propriedades físico-químicas das farinhas obtidas.

Os resultados médios das determinações físico-químicas \pm 0 erro padrão da média das amostras de farinha de puba (b.s.), obtidas para todos os tratamentos, estão compilados, por temperatura de fermentação, no Anexo B.

\subsubsection{Teores de fibras}

Estudos conduzidos por Moorthy \& George (1998) indicam claramente que os níveis de fibra mudam dependendo das condições da fermentação. A quantidade e o tipo de fibra, solúvel ou insolúvel, presentes nas farinhas influem nas suas propriedades viscoamilográficas.

\subsubsection{Fibras insolúveis}

Os teores de fibras insolúveis encontrados foram inferiores aos presentes originalmente na matéria prima $(5,13 \mathrm{~g} / 100 \mathrm{~g})$. Todavia, Menezes et al. (1999) relataram que os teores de fibras insolúveis das amostras fermentadas naturalmente foram semelhantes aos das raízes utilizadas como matéria-prima.

Pode-se observar um rápido decréscimo nos teores de fibras insolúveis na temperatura de $25^{\circ} \mathrm{C}$ até 48 horas em relação a matéria-prima, seguida de elevação até 72 horas de incubação (Figura 27). No intervalo entre 72 e 96 horas observou-se que na fermentação natural, os teores se elevaram enquanto nos tratamentos adicionados de enzima os teores diminuíram. 
O teor médio mínimo encontrado a $25^{\circ} \mathrm{C}$ durante 96 horas foi de $3,44 \%$ para as amostras adicionadas de enzima, contra 4,44\% nas amostras obtidas pela fermentação natural, indicando que a enzima, reduziu ainda mais os teores de fibra, tanto em relação a matéria-prima quanto ao aumento do período de maceração.

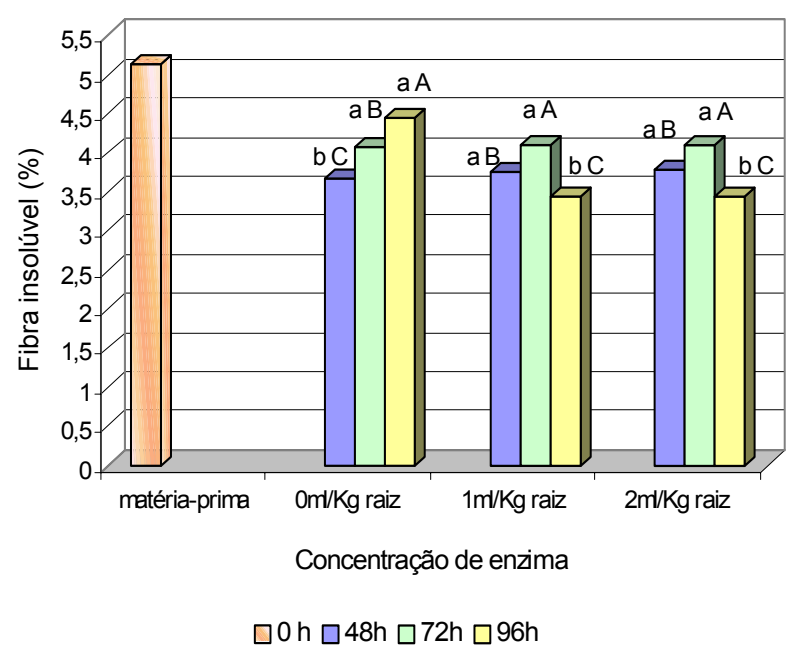

Figura 27 - Fibras insolúveis da matéria-prima e das pubas fermentadas a $25^{\circ} \mathrm{C}$.

Letras minúsculas comparam médias de três repetições dentro de cada tempo e, letras maiúsculas comparam médias dentro de cada concentração de enzima, ao nível de $5 \%$ pelo teste de Tukey.

Na Figura 28 verifica-se que com 48 horas de fermentação, as pubas obtidas a $30^{\circ} \mathrm{C}$, os teores de fibras se mantiveram praticamente estáveis com 0 aumento da concentração de enzima, havendo uma pequena diminuição no tratamento adicionado de $2 \mathrm{~mL}$ de enzima. Até 72 horas houve redução nos teores de fibras com o aumento da concentração de enzima, o inverso ocorreu com 96 horas

Resultados diversos quanto aos teores de fibras têm sido relatados. Para Numfor et al. (1995) não há modificações substanciais no conteúdo deste componente durante a fermentação enquanto para George et al. (1995), os teores de fibras brutas aumentaram durante a fermentação usando inóculo de cultura mista.

$\mathrm{Na}$ literatura existem relatos tanto de aumento (Okolie et al., 1992; Bokanga et al., 1990; George et al., 1995) como de diminuição (Olivieri et al., 1999; Menezes et al., 1999) e estabilização (Numfor et al., 1995) dos teores de fibras durante a fermentação da mandioca para produção de diversas farinhas. 


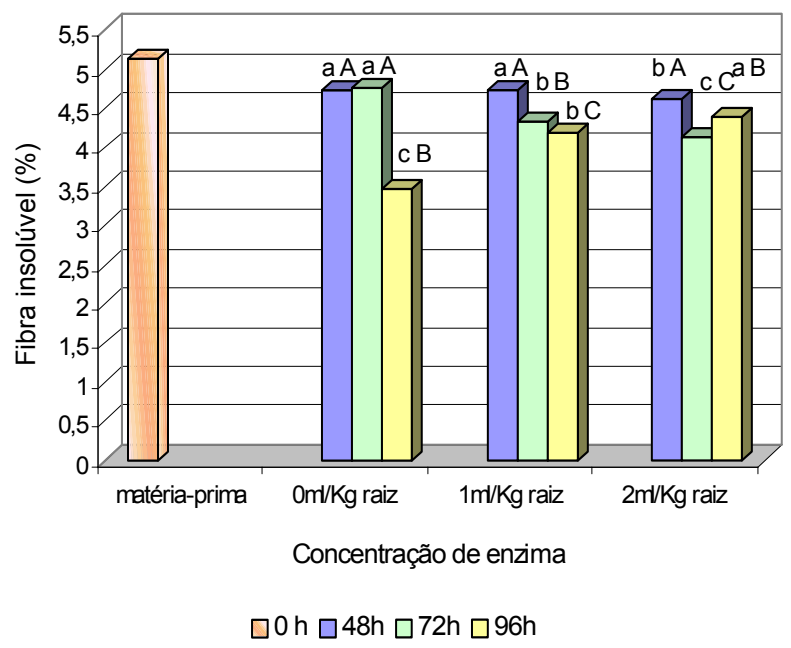

Figura 28 - Fibras insolúveis da matéria-prima e das pubas fermentadas a $30^{\circ} \mathrm{C}$.

Letras minúsculas comparam médias de três repetições dentro de cada tempo e, letras maiúsculas comparam médias dentro de cada concentração de enzima, ao nível de $5 \%$ pelo teste de Tukey.

Menezes et al. (1999) observaram que os teores de fibras insolúveis não diferiram substancialmente nas diferentes amostras tratadas com diferentes concentrações de enzima, com exceção da amostra tratada com 1,5g de celulase/ $\mathrm{Kg}$ de raiz, cujo valor, de 6,0\%, foi superior às demais.

A $35^{\circ} \mathrm{C}$ houve redução dos teores de fibra com o aumento da concentração de enzima que foi mais evidente até 72 horas. A partir deste período os teores de fibras aumentaram nos tratamentos com enzima (Figura 29).

Observa-se pelas Figuras 27, 28 e 29 que a variação dos teores de fibras com 48 horas de incubação foram semelhantes em todos os tratamentos, o mesmo não ocorrendo com 72 e 96 horas. Os tratamentos com enzima apresentaram maiores variações do que a fermentação natural, provavelmente devido a maceração mais intensa e conseqüente perdas por lixiviação. 


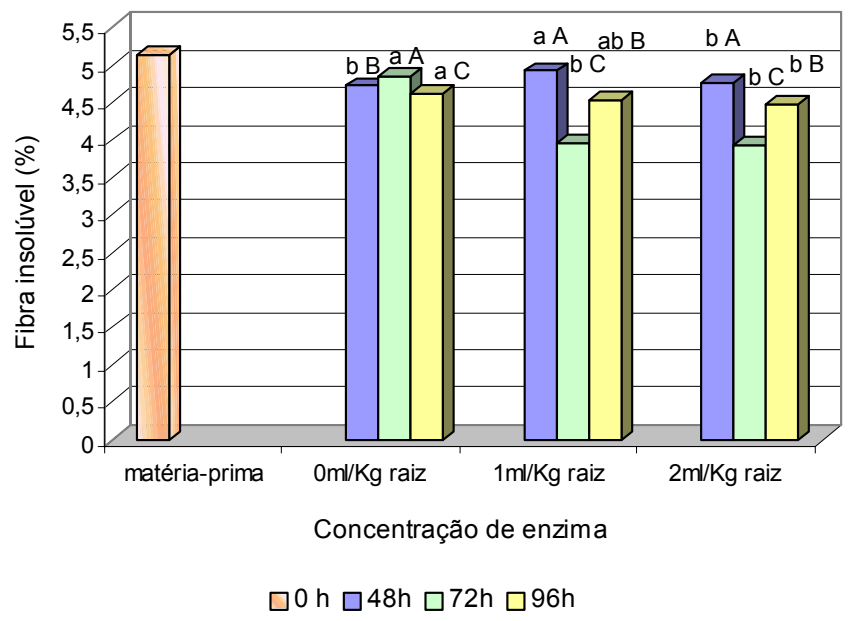

Figura 29 - Fibras insolúveis da matéria-prima e das pubas fermentadas a $35^{\circ} \mathrm{C}$. Letras minúsculas comparam médias de três repetições dentro de cada tempo e, letras maiúsculas comparam médias dentro de cada concentração de enzima, ao nível de $5 \%$ pelo teste de Tukey.

Os resultados da análise estatística e valores de $\mathrm{F}$ obtidos para todas as temperaturas de fermentação estão apresentados na Tabela 16.

Tabela 16. Análise estatística dos teores de fibras insolúveis.

\begin{tabular}{llll}
\hline \multicolumn{2}{c}{ Causas de variação } & \multicolumn{3}{l}{ Valores de $\mathrm{F}$} \\
\hline Temperatura & $25^{\circ} \mathrm{C}$ & $30^{\circ} \mathrm{C}$ & $35^{\circ} \mathrm{C}$ \\
\hline Tempo & $560,57^{* *}$ & $2049,35^{* *}$ & $638,24 * *$ \\
Concentração de enzima & $392,71^{* *}$ & $43,92^{* *}$ & $273,94 * *$ \\
Tempo $\times$ Concentração de enzima & $595,34 * *$ & $965,11 * *$ & $281,09 * *$ \\
\hline ** significativo ao nível de 1\% & Coeficiente de & Coeficiente de & Coeficiente de \\
$*$ significativo ao nível de 5\% & variação: 0,534 & variação: 0,423 & variação: 0,587 \\
n.s.: não significativo ao nível de 5\% & &
\end{tabular}

De acordo com o resultado da análise de variância, os teores de fibras insolúveis mostraram efeito significativo $(p<0,05)$ tanto para variável enzima, como para variável tempo, assim como para interação tempo $X$ enzima. Este resultado coincidiu para todas as temperaturas (Tabela 16) demonstrando que o parâmetro sofreu a influência de todos os tratamentos e temperaturas isoladamente, além da influência que um fator (tempo) tem sobre a ação do outro fator (concentração de enzima). 


\subsubsection{Fibras solúveis}

De forma geral o comportamento para os teores de fibras solúveis foi bastante diversificado. As oscilações nos teores de fibras solúveis ocorridas ao longo do processo fermentativo podem ser visualizadas nas Figuras 30, 31.e 32.

Na temperatura de $25^{\circ} \mathrm{C}$, tanto o maior quanto o menor teor de fibra solúvel foi encontrado com 48 horas de fermentação. O maior valor, no tratamento adicionado de $1 \mathrm{~mL}$ de enzima/Kg (3,64\%) e o menor no adicionado $2 \mathrm{~mL}$ (2,42\%). Após este período os teores oscilaram até 72 horas, tendendo a uma estabilização até 96 horas (Figura 30).

Pequenas variações nos teores de fibras solúvel foram observadas durante todo o período de fermentação natural a $25^{\circ} \mathrm{C}$. Aumentando-se a concentração de enzima ocorreram rápidas diminuições dos teores após 48 horas.

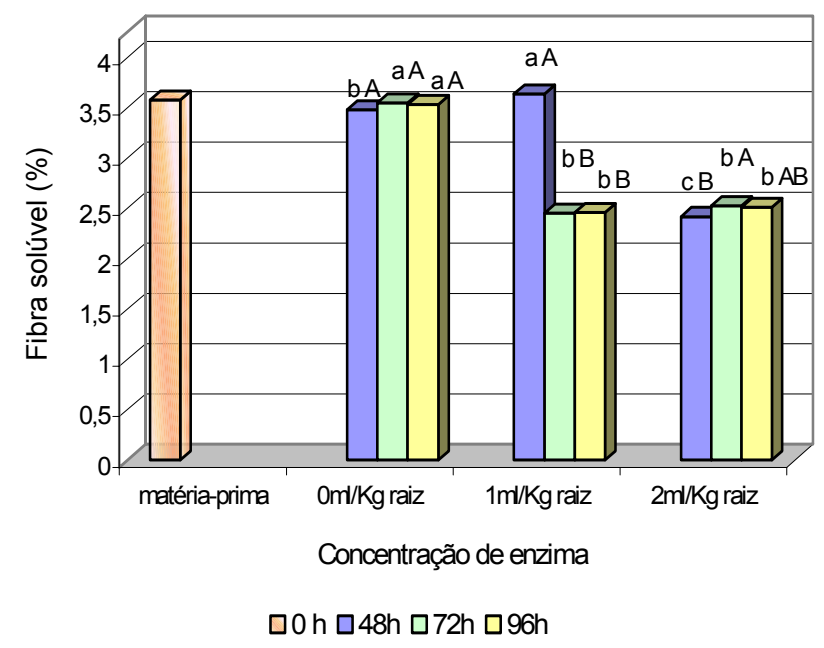

Figura 30 - Fibras solúveis da matéria-prima e das pubas fermentadas a $25^{\circ} \mathrm{C}$.

Letras minúsculas comparam médias de três repetições dentro de cada tempo e, letras maiúsculas comparam médias dentro de cada concentração de enzima, ao nível de $5 \%$ pelo teste de Tukey.

Para a temperatura de $30^{\circ} \mathrm{C}$, nos tratamentos adicionados de enzima, os teores de fibras solúveis decresceram rapidamente até 48 horas elevando-se posteriormente até 72 horas quando os teores oscilam diferentemente até 96 horas 
(Figura 31). A fermentação natural apresentou diminuição ao longo do tempo até atingir o menor teor, cerca de 2,33\% com 96 horas de fermentação.

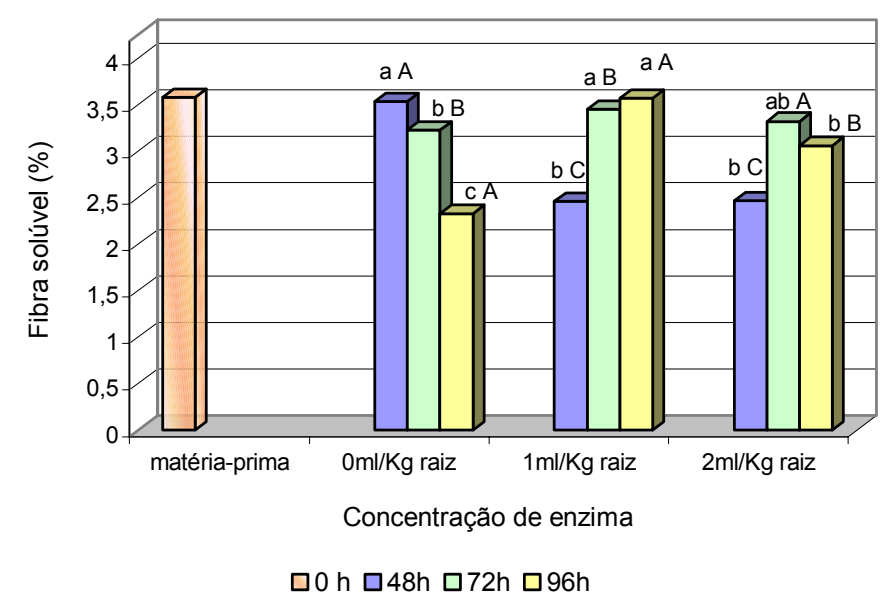

Figura 31 - Fibras solúveis da matéria-prima e das pubas fermentadas a $30^{\circ} \mathrm{C}$. Letras minúsculas comparam médias de três repetições dentro de cada tempo e letras maiúsculas comparam médias dentro de cada concentração de enzima, ao nível de $5 \%$ pelo teste de Tukey.

Os aumentos dos teores de fibras, durante a fermentação de mandioca para produção de farinha amilácea, foram atribuídos por George et al. (1995), à ação de enzimas pectinolíticas e celulolíticas produzidas por inóculos de cultura adicionadas. Estas enzimas quebram a membrana da parede celular e as partículas residuais resultantes também passam pela peneira durante a limpeza, levando a recuperação de uma farinha mais fibrosa. É oportuno ressaltar que na fabricação de farinha amilácea a massa fermentada que atravessa pela peneira será utilizada para sua produção, enquanto na puba é o contrário. A massa fermentada retida no escorredouro e no tecido de algodão utilizado para lavagem dará origem a puba.

A $35^{\circ} \mathrm{C}$ na fermentação natural houve pequeno aumento nos teores de fibras solúveis com 48 horas de fermentação, seguido de uma queda abrupta após este período. $O$ aumento na concentração de enzima resultou na diminuição dos teores de fibras até 48 horas, que voltaram a aumentar após este período. 
Para todos os tratamentos os teores tenderam a aumentar no período entre 72 e 96 horas (Figura 32).

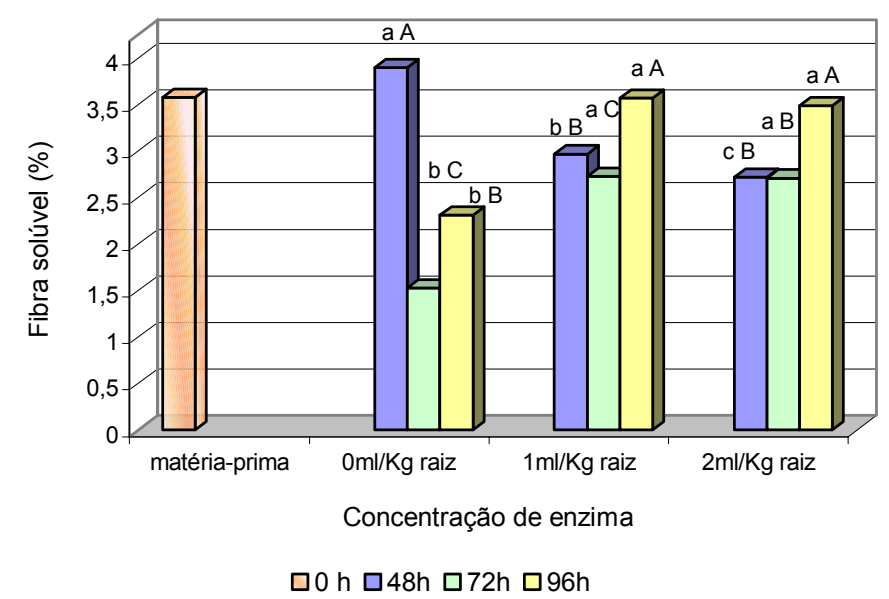

Figura 32 - Fibras solúveis da matéria-prima e das pubas fermentadas a $35^{\circ} \mathrm{C}$.

Letras minúsculas comparam médias de três repetições dentro de cada tempo e, letras maiúsculas comparam médias dentro de cada concentração de enzima, ao nível de $5 \%$ pelo teste de Tukey.

Para Menezes et al. (1999) os teores de fibras solúveis diminuíram nas amostras de puba fermentadas com e sem adições de enzimas em relação ao teor da matéria-prima, o que coincidiu também com as observações de Longe (1980) que detectou redução nos teores de fibras dietéticas na maioria dos produtos fermentados da mandioca.

No presente experimento foi utilizado enzima pectinolítica, que provavelmente atuou reduzindo o tamanho das fibras solúveis, resultando em perda de maior quantidade de fibra nas etapas de escorrimento e lavagem. Tal fato poderia explicar a diminuição dos teores de fibra que ocorre neste processo em relação ao presente inicialmente na matéria-prima.

Conforme foi relatado anteriormente, vários fatores envolvidos na fermentação podem interferir nos teores de fibras. O aumento nos teores de fibras em períodos prolongados de fermentação pode ocorrer devido a predominância de leveduras, tolerantes a baixos valores de $\mathrm{pH}$, em relação às bactérias. Isto porque as leveduras continuam degradando os polissacarídeos ao longo do período resultando 
numa redução dos níveis de fibra dietética. Conforme opinião de Okolie et al. (1992) para se conseguir um aumento nos níveis de fibra dietéticas no produto final, a fermentação bacteriana deve ser superior a fermentação por leveduras.

Os resultados da análise estatística e valores de $\mathrm{F}$ obtidos para todas as temperaturas de fermentação, estão apresentados na Tabela 17.

Tabela 17. Análise estatística dos teores de fibras solúveis

\begin{tabular}{llll}
\hline \multicolumn{2}{c}{ Causas de variação } & \multicolumn{3}{l}{ Valores de $\mathrm{F}$} \\
\hline Temperatura & $25^{\circ} \mathrm{C}$ & $30^{\circ} \mathrm{C}$ & $35^{\circ} \mathrm{C}$ \\
\hline Tempo & $407,83^{* *}$ & $300,04 * *$ & $1719,53^{* *}$ \\
Concentração de enzima & $2817,75^{* *}$ & $49,54 * *$ & $528,73^{* *}$ \\
Tempo $\times$ Concentração de enzima & $606,77^{* *}$ & $552,54 * *$ & $1384,08^{* *}$ \\
\hline ** significativo ao nível de $1 \%$ & Coeficiente de & Coeficiente de & Coeficiente de \\
$*$ significativo ao nível de 5\% & variação: 0,820 & variação: 1,205 & variação: 0,996 \\
n.s.: não significativo ao nível de $5 \%$ & &
\end{tabular}

O resultado da análise de variância para os teores de fibras solúveis mostraram efeito significativo $(p<0,05)$ tanto para variável enzima, como tempo, e para a interação tempo $X$ enzima. Este resultado coincidiu para todas as temperaturas (Tabela 17) demonstrando que o parâmetro sofreu a influência de todos os tratamentos testados além da temperatura.

\subsubsection{Teores de amido}

Como era de se esperar, os teores de amido também diminuíram com o tempo (Figuras 33, 34 e 35) de incubação em relação ao presente nas raízes no início do processo $(88,91 \%)$.

Os teores de amido sempre diminuem em relação à matéria-prima no decorrer da fermentação da mandioca (Moorthy \& George, 1998; Menezes et al., 1999). Esta redução no conteúdo de amido é atribuída, na maioria das vezes, à conversão de açúcares pelos microrganismos durante a fermentação (Meuser et al., 1980). 
A $25^{\circ} \mathrm{C}$ (Figura 33) os teores de amido diminuíram em relação ao aumento da concentração de enzima durante todo o processo fermentativo.

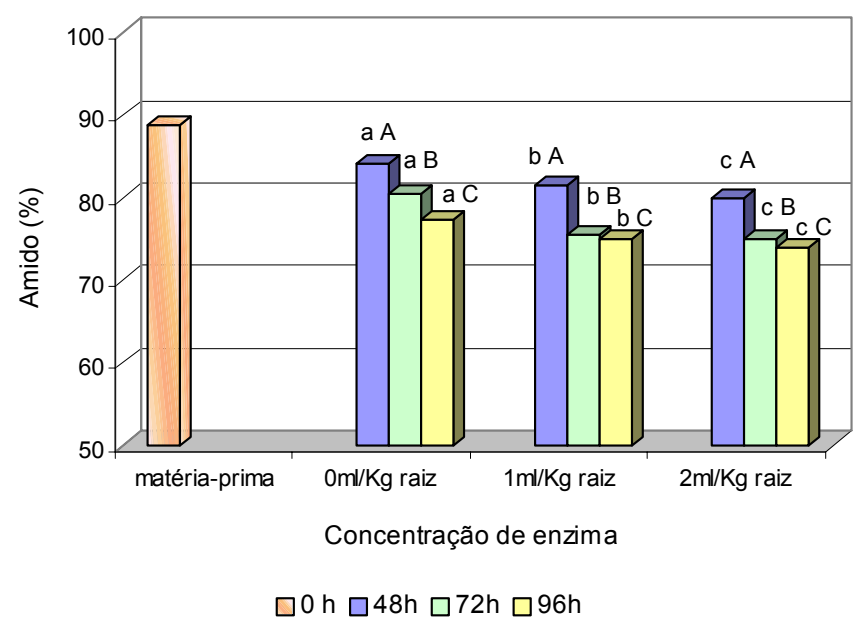

Figura 33 - Amido da matéria-prima e das pubas fermentadas a $25^{\circ} \mathrm{C}$.

Letras minúsculas comparam médias de três repetições dentro de cada tempo e, letras maiúsculas comparam médias dentro de cada concentração de enzima, ao nível de $5 \%$ pelo teste de Tukey.

Tanto a $25^{\circ} \mathrm{C}$ quanto a $30^{\circ} \mathrm{C}$ os teores de amido encontrados na fermentação natural, foram maiores para todos os períodos de incubação, que os encontrados nos tratamentos com enzimas (Figuras 33 e 34 ). Nos tratamentos a $35^{\circ} \mathrm{C}$ (Figura 35), os teores diminuíram durante todo o período de fermentação natural. Aumentando-se a concentração de enzima os teores de amido diminuíram com 48 horas. Estes resultados diferem dos encontrados por alguns trabalhos que relatam que tratamentos enzimáticos levam ao aumento da retenção de amido durante a fermentação (George et al., 1995; Olivieri et al., 1998).

A $35^{\circ} \mathrm{C}$ os teores de amido também diminuem até 48 horas. Para os tratamentos adicionados de enzima os teores voltam a aumentar com 72 horas. Já com 96 horas os teores se mantém estáveis com o aumento da concentração de enzima (Figura 35). Estes resultados, provavelmente indicam que a fermentação tornou-se estável à partir de 72 horas de incubação, não havendo grande consumo de amido pelos microrganismos. 


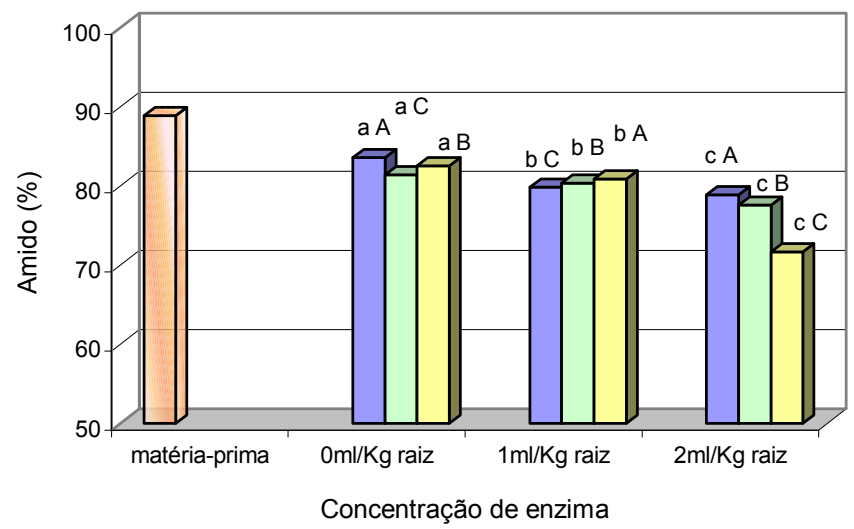

$\square 0 \mathrm{~h} \square 48 \mathrm{~h} \square 72 \mathrm{~h} \square 96 \mathrm{~h}$

Figura 34 - Amido da matéria-prima e das pubas fermentadas a $30^{\circ} \mathrm{C}$.

Letras minúsculas comparam médias de três repetições dentro de cada tempo e, letras maiúsculas comparam médias dentro de cada concentração de enzima, ao nível de $5 \%$ pelo teste de Tukey.

A perda do amido para todos os tratamentos, assim como para os demais componentes, pode ocorrer pela lixiviação no líquido de maceração, que transporta o amido para fora do sistema, ou pode ser consumido pelos microrganismos responsáveis pela fermentação.

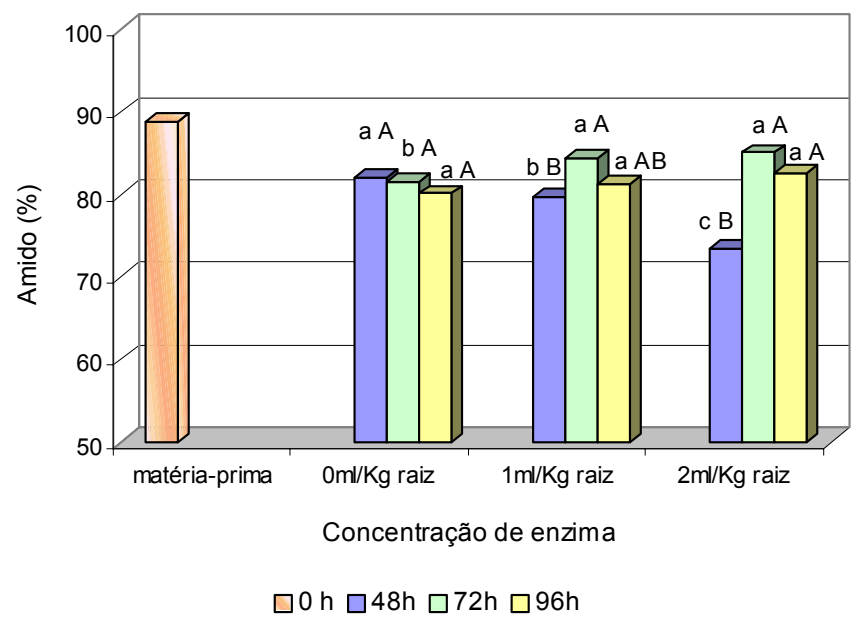

Figura 35 - Amido da matéria-prima e das pubas fermentadas a $35^{\circ} \mathrm{C}$.

Letras minúsculas comparam médias de três repetições dentro de cada tempo e, letras maiúsculas comparam médias dentro de cada concentração de enzima, ao nível de $5 \%$ pelo teste de Tukey. 
Os resultados da análise estatística e valores de $\mathrm{F}$ para todas as temperaturas de fermentação, estão apresentados na Tabela 18.

Tabela 18. Análise estatística dos teores de amido.

\begin{tabular}{llll}
\hline \multicolumn{1}{c}{ Causas de variação } & \multicolumn{3}{l}{ Valores de $\mathrm{F}$} \\
\hline Temperatura & $25^{\circ} \mathrm{C}$ & $30^{\circ} \mathrm{C}$ & $35^{\circ} \mathrm{C}$ \\
\hline Tempo & $10804,2^{* *}$ & $950,62^{* *}$ & $21,57^{* *}$ \\
Concentração de enzima & $5055,39^{* *}$ & $7013,17^{* *}$ & $2,76^{*}$ \\
Tempo $\times$ Concentração de enzima & $203,70 * *$ & $1286,73^{* *}$ & $22,53^{* *}$ \\
\hline ** significativo ao nível de $1 \%$ & Coeficiente de & Coeficiente de & Coeficiente de \\
* significativo ao nível de $5 \%$ & variação: 0,142 & variação: 0,170 & variação: 2,068 \\
n.s.: não significativo ao nível de $5 \%$ & &
\end{tabular}

De acordo com o resultado da análise de variância, os teores de amido mostraram efeito significativo $(p<0,05)$ tanto para variável enzima, como tempo, assim como para interação tempo $\mathrm{X}$ enzima. Este resultado coincidiu para todas as temperaturas (Tabela 18) sem exceção, demonstrando que o parâmetro sofreu a influência de todos os tratamentos em todas as temperaturas.

\subsubsection{Teores de amilose}

A variação dos teores de amilose foi bastante diversificado, ocorrendo tanto o decréscimo quanto o aumento ao longo do período de fermentação, sem apresentar portanto uma oscilação definida.

A Figura 36 representa os teores de amilose da matéria-prima e das pubas obtidas a $25^{\circ} \mathrm{C}$. Pode-se observar que na fermentação natural, as amostras de puba sofreram pequenas oscilações nos teores de amilose ao longo do tempo, quando comparada com os tratamentos adicionados de enzima.

O maior teor de amilose encontrado foi o de $14,12 \%$ no tratamento com de $1 \mathrm{~mL}$ de enzima por 48 horas, superior ao encontrado na matéria-prima (14,05\%). 0 menor teor $(13,02 \%)$, também neste período foi obtido no tratamento com de $2 \mathrm{~mL}$ de enzima/Kg de raiz. Com 72 e 96 horas o aumento da concentração de enzima resulta em diminuição nos teores de amilose. 


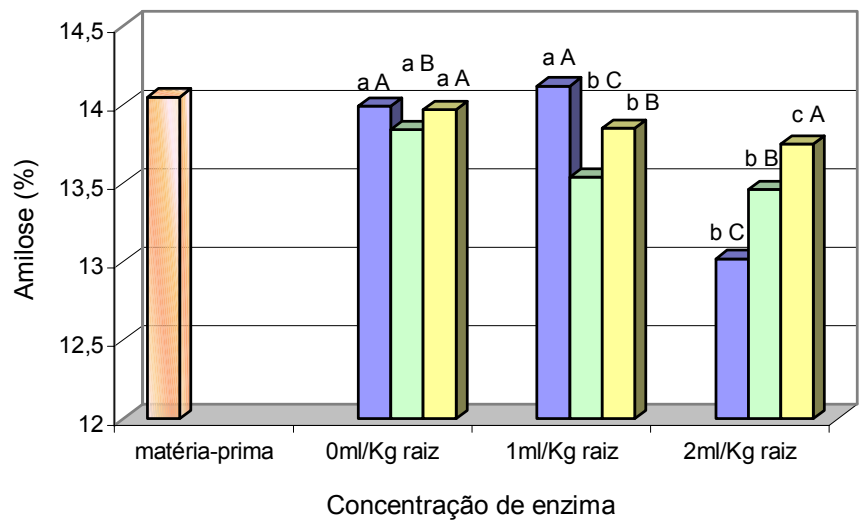

$\square 0 \mathrm{~h} \square$ 48h $\square 72 \mathrm{~h} \square 96 \mathrm{~h}$

Figura 36 - Amilose da matéria-prima e das pubas fermentadas a $25^{\circ} \mathrm{C}$.

Letras minúsculas comparam médias de três repetições dentro de cada tempo e, letras maiúsculas comparam médias dentro de cada concentração de enzima, ao nível de $5 \%$ pelo teste de Tukey.

$\mathrm{Na}$ temperatura de $30^{\circ} \mathrm{C}$ (Figura 37), nenhum tratamento apresentou teores de amilose superior ao presente na matéria-prima (14,05\%). Os menores teores foram encontrados nesta temperatura $(12,71 \%)$ determinados em amostras de puba obtidas com 48 horas de fermentação no tratamento com $1 \mathrm{~mL}$ de enzima/Kg de raiz.

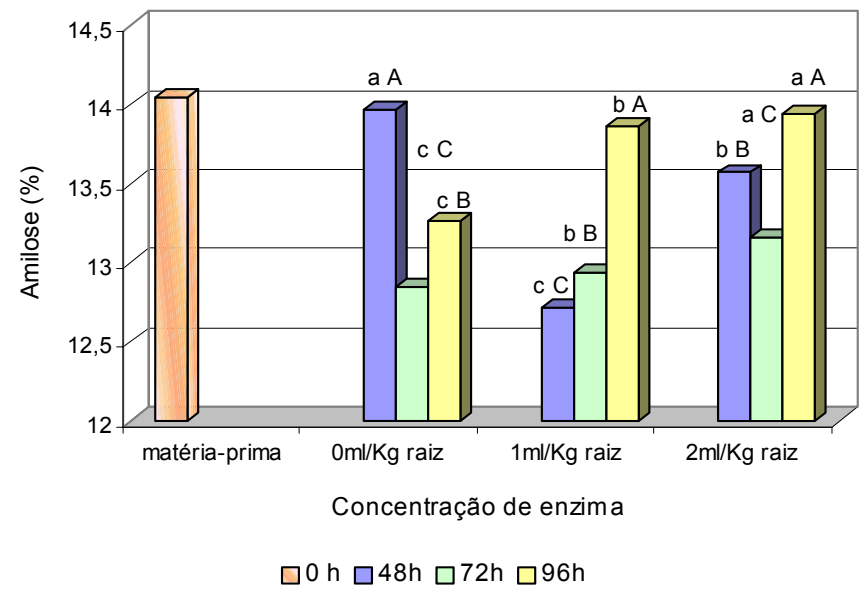

Figura 37 - Amilose da matéria-prima e das pubas fermentadas a $30^{\circ} \mathrm{C}$. Letras minúsculas comparam médias de três repetições dentro de cada tempo e, letras maiúsculas comparam médias dentro de cada concentração de enzima, ao nível de $5 \%$ pelo teste de Tukey. 
A $30^{\circ} \mathrm{C}$, na fermentação natural os teores de amilose diminuem no decorrer do processo, alcançando valores mínimos em 72 horas de fermentação. Com $1 \mathrm{~mL}$ de enzima/Kg de raiz ocorreu um aumento dos teores de amilose durante 0 processo.

É conveniente considerar que como a amilose é um constituinte do amido, as alterações ocorridas nos teores de amido podem se refletir nos teores de amilose. De maneira geral os teores de amido diminuíram ao longo do processamento (Figuras 33, 34 e 35).

Para alguns autores, os processos fermentativos ocasionam diminuição no conteúdo de amilose, comportamento observado em alguns tratamentos no presente trabalho. Segundo Phan \& Mercier, (1984), ácidos orgânicos produzidos durante a fermentação formam complexos com a fração solúvel da amilose, levando com isso uma redução aparente no conteúdo de amilose solúvel. Contudo, tal redução de amilose não foi relatada em alguns trabalhos (Camargo et al., 1988; Martinez \& Quiroga, 1988).

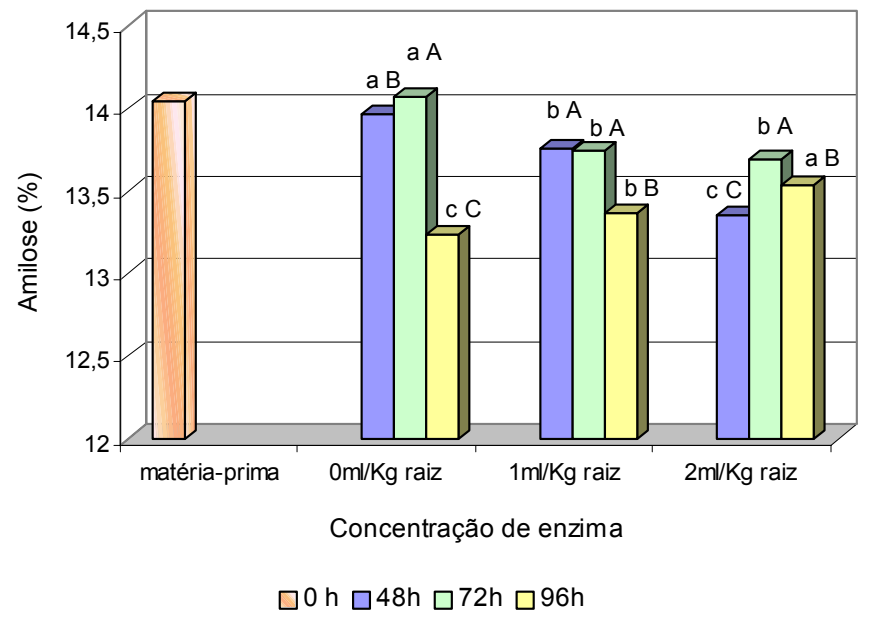

Figura 38 - Amilose da matéria-prima e das pubas fermentadas a $35^{\circ} \mathrm{C}$.

Letras minúsculas comparam médias de três repetições dentro de cada tempo e, letras maiúsculas comparam médias dentro de cada concentração de enzima, ao nível de $5 \%$ pelo teste de Tukey.

Na Figura 38 pode-se observar que a $35^{\circ} \mathrm{C}$ na fermentação natural os teores de amilose $(14,07 \%)$ foram semelhantes ao encontrados na matéria-prima 
$(14,05 \%)$, e que de forma geral os teores tenderam a diminuir em relação ao presente originalmente nas raízes.

Verificou-se também que com 48 horas os teores de amilose decresceram com 0 aumento da concentração de enzima. Porém com 96 horas o comportamento se altera tendendo a aumentar com o aumento da concentração de enzima (Figura 38).

Alguns autores como Numfor et al. (1995) relataram aumento no conteúdo de amilose em relação a raiz, nos produtos obtidos pela fermentação natural da mandioca ou utilizando inóculo de cultura mista. Este resultado não é usual e pode ser explicado pela provável formação de amilose como material resultante das enzimas e hidrólises ácidas da amilopectina das regiões amorfas do grânulo de amido durante a fermentação.

Os resultados da análise estatística e valores de $\mathrm{F}$ para todas as temperaturas de fermentações, estão apresentados na Tabela 19.

Tabela 19. Análise estatística dos teores de amilose.

\begin{tabular}{llll}
\hline \multicolumn{1}{c}{ Causas de variação } & \multicolumn{3}{l}{ Valores de $\mathrm{F}$} \\
\hline Temperatura & $25^{\circ} \mathrm{C}$ & $30^{\circ} \mathrm{C}$ & $35^{\circ} \mathrm{C}$ \\
\hline Tempo & $26,18^{* *}$ & $1646,23^{* *}$ & $785,74^{* *}$ \\
Concentração de enzima & $170,02^{* *}$ & $479,53^{* *}$ & $193,52^{* *}$ \\
Tempo $\times$ Concentração de enzima & $79,85 * *$ & $994,07 * *$ & $292,86^{* *}$ \\
\hline ** significativo ao nível de $1 \%$ & Coeficiente de & Coeficiente de & Coeficiente de \\
$*$ significativo ao nível de 5\% & variação: 0,441 & variação: 0,441 & variação: 0,182 \\
n.s.: não significativo ao nível de $5 \%$ & & &
\end{tabular}

De acordo com o resultado da análise de variância, os teores de amilose mostraram efeito significativo $(p<0,05)$ tanto para variável enzima, quanto para 0 tempo, assim como para interação tempo X enzima. Este resultado coincidiu para todas as temperaturas (Tabela 19) o que demonstra que parâmetro sofreu a influência de todos os tratamentos além da temperatura. 


\subsubsection{Teores de açúcares solúveis totais}

Os teores de açúcares solúveis totais diminuíram com o tempo, para todas as temperaturas de incubação, em relação ao presente na matéria-prima $(2,40 \%)$ no início do processo.

A Figura 39 apresenta os teores de açúcares solúveis totais da matériaprima e das pubas obtidas a $25^{\circ} \mathrm{C}$. O maior teor foi de $1,97 \%$ obtido no tratamento testemunha com 48 horas de fermentação. 0 menor teor encontrado foi de $0,92 \%$ no tratamento adicionado de $1 \mathrm{~mL}$ de enzima com 96 horas de incubação.

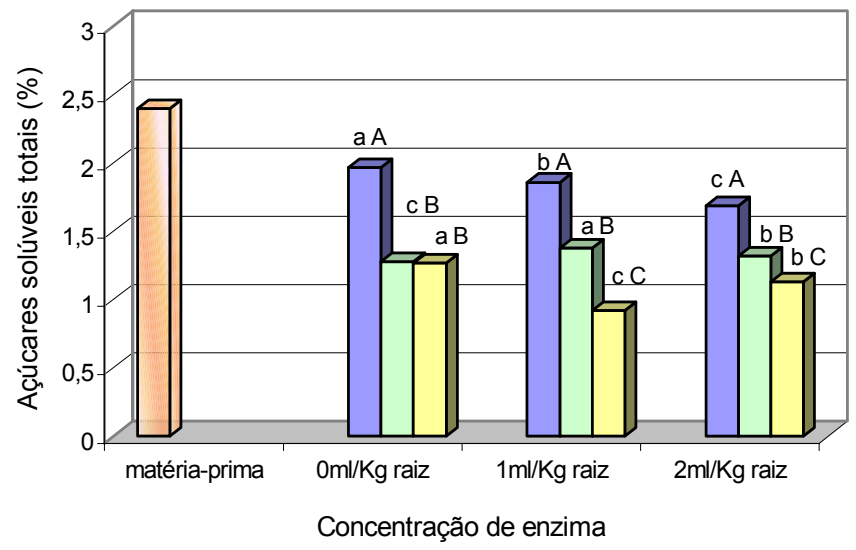

$\square 0 \mathrm{~h} \square 48 \mathrm{~h} \square 72 \mathrm{~h} \square 96 \mathrm{~h}$

Figura 39 - Açúcares solúveis totais da matéria-prima e das pubas fermentadas a $25^{\circ} \mathrm{C}$. Letras minúsculas comparam médias de três repetições dentro de cada tempo e, letras maiúsculas comparam médias dentro de cada concentração de enzima, ao nível de $5 \%$ pelo teste de Tukey.

Para todas as concentrações de enzima o período de incubação 48 horas apresentou os maiores teores de açúcares solúveis totais, embora estes tenham sido menores quanto maior a concentração de enzima. Apenas no tratamento testemunha houve uma estabilização após 72 horas até 96 horas.

A $25^{\circ} \mathrm{C}$ os teores açúcares solúveis diminuíram durante a pubagem quer na fermentação natural, quer nos tratamentos com enzima. Aumentando-se a concentração de enzima houve diminuição dos teores de açúcar até 48 horas. Olivieri et al. (1999) relataram o decréscimo de açúcares solúveis ao longo do processo fermentativo de mandioca para produção de puba. 
A literatura menciona o comportamento variado com respeito aos teores de açúcares solúveis na fermentação de mandioca. Segundo Meuser (1978); Longe (1980); George et al. (1995); Nunfor et al. (1995) e Olivieri et al. (1999) esses valores podem reduzir, ou aumentar no primeiro dia de fermentação, reduzindo posteriormente (Ogunsua, 1980; Oyewole \& Odunfa, 1989).

$\mathrm{Na}$ temperatura de $30^{\circ} \mathrm{C}$ o maior teor encontrado foi $1,43 \%$ na fermentação natural com 48 horas de fermentação, condições nas quais foram encontrados os maiores valores de açúcares solúveis, tanto a $25^{\circ} \mathrm{C}$ (Figura 39 ) quanto a $35^{\circ} \mathrm{C}$ (Figura 40). Maiores quantidades de açúcares estavam disponíveis aos microrganismos em estádios iniciais de fermentação.

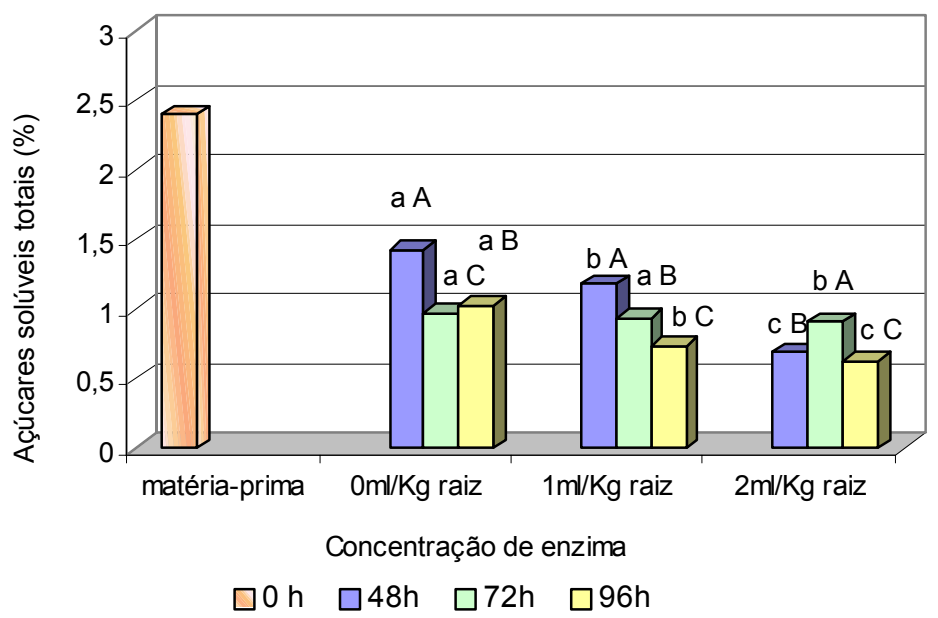

Figura 40 - Açúcares solúveis totais da matéria-prima e das pubas fermentadas a $30^{\circ} \mathrm{C}$. Letras minúsculas comparam médias de três repetições dentro de cada tempo e, letras maiúsculas comparam médias dentro de cada concentração de enzima, ao nível de $5 \%$ pelo teste de Tukey.

Moorthy \& George (1998) também relataram que os açúcares geralmente são utilizados pelos microrganismos para o seu crescimento, por isso o seu decréscimo. Alguns relatos da literatura sugerem que os teores de açúcar aumentam, e atribuem a sua disponibilização através da quebra do amido por enzimas. Posteriormente, estes teores voltam a diminuir pois os açúcares disponíveis são utilizados pelos microrganismos (Ogunsua, 1980). Estas enzimas podem ter origem endógena ou serem produzidos por microrganismos responsáveis pela fermentação. 
Verificou-se que na temperatura de $35^{\circ} \mathrm{C}$ os teores de açúcares solúveis total diminuíram durante todo o processo, quer na fermentação natural quer nos tratamentos adicionados de enzima (Figura 41). O menor teor encontrado foi de 0,70\% no tratamento adicionado de $2 \mathrm{~mL}$ de enzima por 96 horas, embora este valor não tenha sido diferente estatisticamente dos encontrados para 0 e $1 \mathrm{~mL}$ de enzima/96 horas $(0,73 \%)$. Esses teores são bem menores que os encontrados nas temperaturas de 25 e $30^{\circ} \mathrm{C}$, indicando fermentação mais intensa.

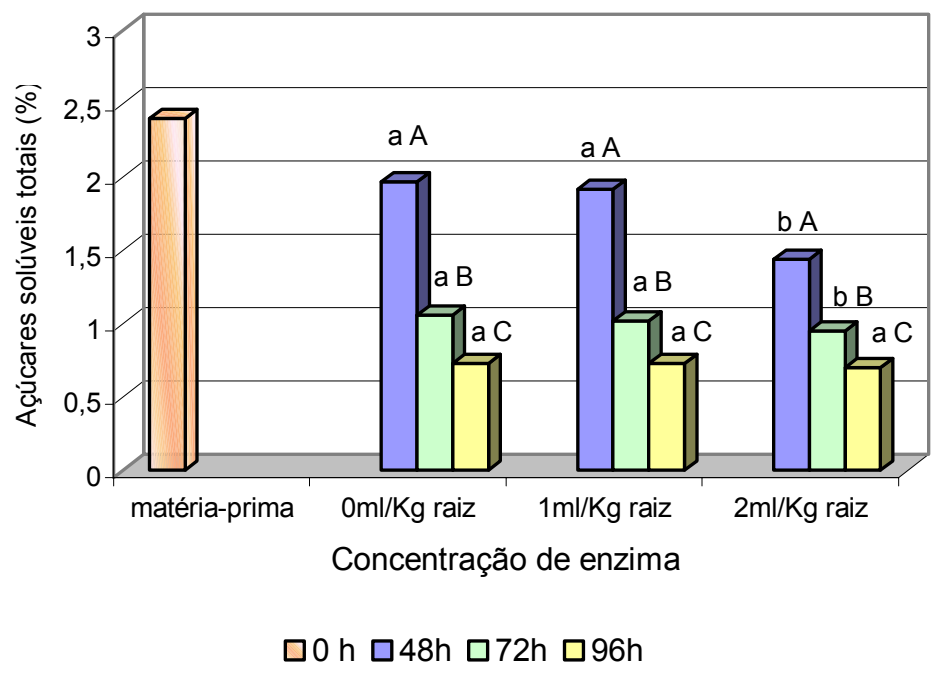

Figura 41 - Açúcares solúveis totais da matéria-prima e das pubas fermentadas a $35^{\circ} \mathrm{C}$. Letras minúsculas comparam médias de três repetições dentro de cada tempo e, letras maiúsculas comparam médias dentro de cada concentração de enzima, ao nível de $5 \%$ pelo teste de Tukey.

A diminuição dos teores de açúcares solúveis ao final de 96 horas de incubação a $25^{\circ} \mathrm{C}$ foram menores do que para outras temperaturas, indicando que a 30 e $35^{\circ} \mathrm{C}$ a fermentação pode ser mais acelerada e os microrganismos teriam consumido mais rapidamente os açúcares solúveis disponíveis.

Almeida (1992) indicou que a temperatura ideal para fermentação natural é em torno de 28 a $32^{\circ} \mathrm{C}$. Entretanto Moorthy \& George (1998), analisando o decréscimo nos teores de açúcares, indicam a temperatura de $35^{\circ} \mathrm{C}$ como ideal para o desenvolvimento microbiano na fermentação da mandioca para produção do fufu.

Segundo Oyewole \& Odunfa (1989) o decréscimo nos teores de açúcar pode ser devido a conversão de açúcares em ácidos orgânicos. Outras possibilidades 
incluem: sua utilização por microrganismos responsáveis pela fermentação ou ainda a sua hidrólise durante o processo.

Os resultados da análise estatística e valores de $\mathrm{F}$ para todas as temperaturas de fermentações, estão apresentados na Tabela 20.

Tabela 20. Análise estatística dos teores de açúcares solúveis totais.

\begin{tabular}{llll}
\hline \multicolumn{1}{c}{ Causas de variação } & \multicolumn{3}{l}{ Valores de F } \\
\hline Temperatura & $25^{\circ} \mathrm{C}$ & $30^{\circ} \mathrm{C}$ & $35^{\circ} \mathrm{C}$ \\
\hline Tempo & $8182,84^{* *}$ & $1662,92^{* *}$ & $9866,85^{* *}$ \\
Concentração de enzima & $295,72^{* *}$ & $2980,50^{* *}$ & $492,19^{* *}$ \\
Tempo $\times$ Concentração de enzima & $350,05^{* *}$ & $821,29 * *$ & $250,94 * *$ \\
\hline ** significativo ao nível de $1 \%$ & Coeficiente de & Coeficiente de & Coeficiente de \\
$*$ significativo ao nível de 5\% & variação: 1,010 & variação:1,337 & variação: 1,631 \\
n.s.: não significativo ao nível de 5\% & & &
\end{tabular}

De acordo com o resultado da análise de variância, os valores de açúcares solúveis totais mostraram efeito significativo $(p<0,05)$ tanto para variável enzima, como tempo, assim como para interação tempo $X$ enzima. Este resultado coincidiu para todas as temperaturas (Tabela 19) demonstrando que o parâmetro sofreu a influência de todos os tratamentos testados e temperaturas. As maiores reduções ocorreram com 96 horas de fermentação demostrando novamente ser este período demasiadamente longo para o processamento de puba 


\section{CONCLUSÕES}

- Os parâmetros do processo fermentativo avaliados no presente trabalho (temperatura, concentração de enzima e tempo) influenciaram características visuais como turvidez do líquido, formação de espuma na superfície, flutuação das raízes e grau de maceração. Tais parâmetros podem dar indícios do estágio de fermentação, inclusive do seu término.

- Os valores de pH do líquido de fermentação diminuem mais rapidamente até 48 horas de maceração, e mais lentamente de 48 a 96 horas. Em nenhuma das temperaturas estudadas os valores de $\mathrm{pH}$ mostraram interação significativa dos fatores tempo e concentração de enzima.

- Os teores de matéria seca nas pubas tenderam a diminuir ao longo do processo fermentativo em relação ao presente nas raízes não fermentadas principalmente para as temperaturas de 30 e $35^{\circ} \mathrm{C}$.

- O rendimento em massa de puba está associado a textura das raízes fermentadas para os experimentos realizados a $30^{\circ} \mathrm{C}$. Texturas próximas a $4 \mathrm{lbf} / \mathrm{g}$ apresentaram maiores rendimentos podendo indicar o final para o processo.

- Para as temperaturas de 25 e $35^{\circ} \mathrm{C}$, não foi encontrada correlação significativa entre os valores de textura e rendimento, assim como para os tempos 48 e 72 horas.

- O ponto final de fermentação, com base no maior rendimento foi obtido para texturas próximas a $4 \mathrm{lbf} / \mathrm{g}$ de amostra, valores estes encontrados com 48 horas de 
- fermentação para temperatura de $30^{\circ} \mathrm{C}$ com rendimento médio de $74,5 \%$, e após um período maior (72 horas) para as temperaturas de $25^{\circ} \mathrm{C}(75,11 \%)$ e $35^{\circ} \mathrm{C}$ $(75,11 \%)$.

- Os valores de textura mais baixos, (próximos de 2,30lbf/g de raiz), foram os que apresentaram menores rendimentos, indicando excesso de maceração dos tecidos além de características indesejáveis de odor e aparência pegajosa ao produto.

- A textura, como método objetivo de avaliação, pode substituir o método subjetivo como as característica visuais, para determinar o ponto final da fermentação.

- Os menores rendimentos em puba foram encontrados nos períodos mais longos de fermentação (96 horas) e para a maior adição de enzima ( $2 \mathrm{ml} / \mathrm{kg}$ de raiz), em todas as temperaturas.

- Maiores rendimentos de puba com boa qualidade, foram obtidos na fermentação natural, na temperatura de $30^{\circ} \mathrm{C}$ durante 48 horas de incubação; e $25^{\circ} \mathrm{C}$ no período de 72 horas de fermentação. Portanto pode-se obter puba com boa qualidade e rendimento elevado, sem utilização de enzima.

- Pubas obtidas a $25^{\circ} \mathrm{C}$ por 48 horas continham pedaços sem macerar, principalmente na fermentação natural. Além de acarretar perdas, as farinhas resultantes apresentavam-se com odor pouco característico da puba.

- O período de 48 horas não foi suficiente para macerar completamente as raízes de mandioca incubadas a temperatura de $25^{\circ} \mathrm{C}$. Já para a temperatura de $30^{\circ}$ foi o período suficiente para obter o maior rendimento deste estudo.

- O período de 96 horas de fermentação foi o que proporcionou os menores rendimentos, em todos os tratamentos para todas as temperaturas, com exceção do tratamento com $1 \mathrm{~mL}$ de enzima a $35^{\circ} \mathrm{C}$, demonstrando ser desnecessário um período tão longo de fermentação. 
- Os teores de fibras insolúveis e solúveis das pubas foram inferiores aos da matériaprima. Não houve padrão de oscilação nos diversos tratamento

- Os teores de amido encontrados nas farinhas de puba, foram inferiores aos determinados na matéria-prima. As perdas de amido ocorridas ao longo do processo tem relação com a turvidez do líquido de fermentação e com o estágio em que a fermentação se encontra.

- Os teores de amilose foram inferiores aos encontrados no início do processo e diminuíram ao longo da pubagem.

- Os teores de açúcares solúveis totais tendem a diminuir com o aumento do período de fermentação. Na temperatura de $35^{\circ} \mathrm{C}$ estes teores também decrescem com aumento da concentração de enzima. Os menores teores para todos os tratamentos foram obtidos com 96 horas de fermentação. 
ANEXOS 
ANEXO A - Resultados de cada repetição de textura, matéria seca, pH e Rendimento final para todas as temperaturas, tempo e concentrações de enzima testados.

\begin{tabular}{|c|c|c|c|c|c|c|c|}
\hline $\mathrm{T}\left({ }^{\circ} \mathrm{C}\right)$ & $\begin{array}{c}\text { Tempo } \\
\text { (h) }\end{array}$ & $\begin{array}{l}\text { [] Enzima } \\
(\mathrm{mL} / \mathrm{Kg})\end{array}$ & Repetição & $\begin{array}{l}\text { Textura } \\
\text { (lbf/g) }\end{array}$ & $\begin{array}{l}\text { M. S. } \\
(\%)\end{array}$ & pH & $\begin{array}{l}\text { RENDIMENTO } \\
\text { FINAL (\%) }\end{array}$ \\
\hline \multirow{9}{*}{ 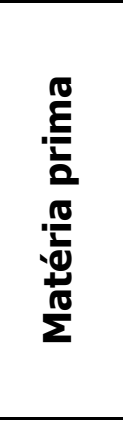 } & 0 & 0 & 1 & 19,45 & 39,65 & 6,8 & \\
\hline & $\mathbf{0}$ & $\mathbf{0}$ & 2 & 18,55 & 39,65 & 6,8 & \\
\hline & 0 & 0 & 3 & 17,86 & 39,65 & 6,8 & \\
\hline & 0 & 1 & 1 & 19,45 & 38,50 & 6,7 & \\
\hline & $\mathbf{0}$ & 1 & 2 & 18,55 & 38,50 & 6,7 & \\
\hline & 0 & 1 & 3 & 17,86 & 38,50 & 6,7 & \\
\hline & 0 & 2 & 1 & 19,45 & 39,75 & 6,6 & \\
\hline & 0 & 2 & 2 & 18,55 & 39,75 & 6,6 & \\
\hline & 0 & 2 & 3 & 17,86 & 39,75 & 6,6 & \\
\hline 25 & 48 & $\overline{0}$ & 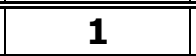 & $7,7,47$ & 393,62 & 4,25 & 71,75 \\
\hline 25 & 48 & $\mathbf{0}$ & 2 & 7,72 & 42,57 & 4,25 & 70,29 \\
\hline 25 & 48 & 0 & 3 & 7,43 & 38,77 & 4,27 & 70,10 \\
\hline 25 & 48 & 1 & 1 & 7,81 & 42,82 & 4,10 & 75,44 \\
\hline 25 & 48 & 1 & 2 & 7,63 & 41,69 & 4,12 & 74,15 \\
\hline 25 & 48 & 1 & 3 & 7,85 & 38,12 & 4,20 & 75,49 \\
\hline 25 & 48 & 2 & 1 & 6,25 & 40,90 & 4,10 & 72,35 \\
\hline 25 & 48 & 2 & 2 & 6,52 & 40,81 & 4,23 & 72,86 \\
\hline 25 & 48 & 2 & 3 & 6,80 & 35,50 & 4,10 & 71,43 \\
\hline 25 & 72 & $\overline{0}$ & 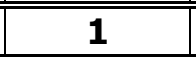 & 3,88 & 38,81 & 4,20 & 74,89 \\
\hline 25 & 72 & $\mathbf{0}$ & 2 & 3,73 & 37,51 & 4,08 & 74,86 \\
\hline 25 & 72 & 0 & 3 & 3,82 & 38,77 & 4,30 & 74,48 \\
\hline 25 & 72 & 1 & 1 & 3,92 & 40,18 & 4,04 & 77,78 \\
\hline 25 & 72 & 1 & 2 & 3,86 & 38,49 & 4,04 & 78,25 \\
\hline 25 & 72 & 1 & 3 & 3,99 & 38,16 & 4,08 & 74,86 \\
\hline 25 & 72 & 2 & 1 & 3,15 & 39,14 & 3,95 & 74,22 \\
\hline 25 & 72 & 2 & 2 & 3,11 & 37,98 & 3,88 & 73,40 \\
\hline 25 & 72 & 2 & 3 & 3,16 & 38,16 & 4,00 & 73,28 \\
\hline 25 & 996 & 0 & $\overline{1} 1$ & 3,49 & 38,56 & 3,90 & 70,76 \\
\hline 25 & 96 & 0 & 2 & 3,37 & 36,51 & 3,90 & 69,37 \\
\hline 25 & 96 & 0 & 3 & 3,44 & 36,87 & 4,00 & 69,22 \\
\hline 25 & 96 & 1 & 1 & 3,44 & 37,06 & 3,70 & 74,89 \\
\hline 25 & 96 & 1 & 2 & 3,32 & 37,70 & 3,70 & 74,12 \\
\hline 25 & 96 & 1 & 3 & 3,46 & 35,78 & 4,00 & 73,38 \\
\hline 25 & 96 & 2 & 1 & 2,99 & 38,09 & 3,60 & 71,67 \\
\hline 25 & 96 & 2 & 2 & 3,07 & 39,14 & 3,70 & 72,95 \\
\hline 25 & 96 & 2 & 3 & 3,05 & 36,52 & 3,90 & 71,21 \\
\hline
\end{tabular}




\begin{tabular}{|c|c|c|c|c|c|c|c|}
\hline $\mathrm{T}\left({ }^{\circ} \mathrm{C}\right)$ & $\begin{array}{c}\text { Tempo } \\
\text { (h) }\end{array}$ & $\begin{array}{l}\text { [] Enzima } \\
(\mathrm{mL} / \mathrm{Kg})\end{array}$ & Repetição & $\begin{array}{c}\text { Textura } \\
\text { (lbf } / g)\end{array}$ & $\begin{array}{l}\text { M. S. } \\
(\%)\end{array}$ & pH & $\begin{array}{c}\text { RENDIMENTO } \\
\text { FINAL (\%) }\end{array}$ \\
\hline 30 & 48 & 0 & 1 & 3,67 & 36,03 & 3,98 & 74,09 \\
\hline 30 & 48 & 0 & 2 & 3,52 & 35,78 & 4,33 & 74,52 \\
\hline 30 & 48 & 0 & 3 & 3,61 & 34,70 & 4,23 & 74,54 \\
\hline 30 & 48 & 1 & 1 & 3,20 & 39,77 & 4,15 & 75,14 \\
\hline 30 & 48 & 1 & 2 & 3,12 & 34,04 & 4,37 & 73,82 \\
\hline 30 & 48 & 1 & 3 & 3,22 & 33,47 & 4,37 & 74,34 \\
\hline 30 & 48 & 2 & 1 & 2,89 & 37,79 & 3,98 & 74,47 \\
\hline 30 & 48 & 2 & 2 & 2,92 & 39,31 & 4,33 & 75,29 \\
\hline 30 & 48 & 2 & 3 & 2,87 & 34,31 & 4,27 & 74,36 \\
\hline 30 & 72 & 0 & 1 & 3,05 & 36,95 & 4,15 & 68,01 \\
\hline 30 & 72 & 0 & 2 & 3,05 & 33,44 & 4,25 & 67,12 \\
\hline 30 & 72 & 0 & 3 & 3,08 & 36,14 & 4,23 & 68,54 \\
\hline 30 & 72 & 1 & 1 & 2,51 & 37,54 & 4,05 & 71,04 \\
\hline 30 & 72 & 1 & 2 & 2,50 & 34,54 & 4,00 & 71,73 \\
\hline 30 & 72 & 1 & 3 & 2,56 & 36,16 & 4,08 & 72,75 \\
\hline 30 & 72 & 2 & 1 & 2,48 & 34,48 & 4,00 & 66,23 \\
\hline 30 & 72 & 2 & 2 & 2,44 & 38,39 & 3,98 & 66,52 \\
\hline 30 & 72 & 2 & 3 & 2,43 & 38,57 & 4,00 & 67,22 \\
\hline 30 & 96 & 0 & 1 & 3,33 & 34,92 & 4,00 & 68,85 \\
\hline 30 & 96 & 0 & 2 & 3,26 & 33,60 & 4,00 & 69,00 \\
\hline 30 & 96 & 0 & 3 & 3,28 & 35,61 & 4,10 & 67,39 \\
\hline 30 & 96 & 1 & 1 & 2,55 & 42,53 & 3,90 & 69,87 \\
\hline 30 & 96 & 1 & 2 & 2,53 & 35,68 & 3,80 & 68,61 \\
\hline 30 & 96 & 1 & 3 & 2,55 & 32,53 & 3,90 & 67,95 \\
\hline 30 & 96 & 2 & 1 & 2,48 & 37,09 & 3,80 & 60,07 \\
\hline 30 & 96 & 2 & 2 & 2,49 & 33,69 & 3,90 & 58,82 \\
\hline 30 & 96 & 2 & 3 & 2,50 & 36,43 & 3,90 & 58,63 \\
\hline 35 & 48 & 0 & 1 & 4,77 & 37,26 & 4,28 & 72,43 \\
\hline 35 & 48 & 0 & 2 & 4,71 & 33,75 & 4,25 & 72,35 \\
\hline 35 & 48 & 0 & 3 & 4,72 & 41,47 & 4,37 & 70,85 \\
\hline 35 & 48 & 1 & 1 & 2,90 & 34,03 & 4,13 & 72,74 \\
\hline 35 & 48 & 1 & 2 & 2,97 & 34,87 & 4,10 & 73,55 \\
\hline 35 & 48 & 1 & 3 & 2,86 & 40,57 & 4,17 & 72,02 \\
\hline 35 & 48 & 2 & 1 & 4,03 & 34,92 & 3,97 & 73,66 \\
\hline 35 & 48 & 2 & 2 & 4,09 & 34,49 & 3,88 & 73,70 \\
\hline 35 & 48 & 2 & 3 & 4,15 & 40,22 & 4,07 & 72,62 \\
\hline 35 & 72 & 0 & 1 & 2,50 & 34,63 & 4,13 & 75,70 \\
\hline 35 & 72 & 0 & 2 & 2,47 & 32,51 & 4,15 & 76,07 \\
\hline 35 & 72 & 0 & 3 & 2,53 & 36,82 & 4,23 & 75,21 \\
\hline 35 & 72 & 1 & 1 & 2,39 & 33,99 & 3,85 & 73,79 \\
\hline 35 & 72 & 1 & 2 & 2,35 & 32,99 & 3,93 & 74,93 \\
\hline 35 & 72 & 1 & 3 & 2,49 & 37,61 & 4,25 & 73,61 \\
\hline
\end{tabular}




\begin{tabular}{|c|c|c|c|c|c|c|c|}
\hline $\mathrm{T}\left({ }^{\circ} \mathrm{C}\right)$ & $\begin{array}{l}\text { Tempo } \\
\text { (h) }\end{array}$ & \begin{tabular}{|c|} 
[] Enzima \\
$(\mathrm{mL} / \mathrm{Kg})$
\end{tabular} & Repetição & $\begin{array}{c}\text { Textura } \\
\text { (lbf/g) }\end{array}$ & $\begin{array}{l}\text { M. S. } \\
(\%)\end{array}$ & pH & \begin{tabular}{|c|} 
RENDIMENTO \\
FINAL (\%)
\end{tabular} \\
\hline 35 & 72 & 2 & 1 & 3,12 & 34,32 & 3,80 & 75,12 \\
\hline 35 & 72 & 2 & 2 & 3,07 & 34,40 & 3,73 & 74,83 \\
\hline 35 & 72 & 2 & 3 & 3,17 & 38,04 & 4,00 & 73,78 \\
\hline 35 & 96 & 0 & 1 & 2,71 & 32,08 & 4,00 & 72,52 \\
\hline 35 & 96 & 0 & 2 & 2,77 & 31,76 & 3,90 & 71,83 \\
\hline 35 & 96 & 0 & 3 & 2,76 & 36,82 & 4,30 & 70,73 \\
\hline 35 & 96 & 1 & 1 & 2,43 & 33,44 & 3,80 & 75,99 \\
\hline 35 & 96 & 1 & 2 & 2,49 & 33,86 & 3,75 & 76,06 \\
\hline 35 & 96 & 1 & 3 & 2,48 & 37,36 & 4,10 & 74,56 \\
\hline 35 & 96 & 2 & 1 & 2,35 & 36,36 & 3,70 & 70,24 \\
\hline 35 & 96 & 2 & 2 & 2,33 & 34,30 & 3,70 & 69,56 \\
\hline 35 & 96 & 2 & 3 & 2,37 & 38,66 & 4,10 & 69,38 \\
\hline
\end{tabular}


ANEXO B- Resultados médios das análises físico-químicas das amostras de farinha de puba obtidas em todos os tratamentos.

\begin{tabular}{|c|c|c|c|c|c|c|c|c|c|}
\hline \multirow{2}{*}{$\begin{array}{l}\text { Tempe- } \\
\text { ratura } \\
\left({ }^{\circ} \mathrm{C}\right)\end{array}$} & \multirow{2}{*}{$\begin{array}{l}\text { Tempo } \\
\text { (h) }\end{array}$} & \multirow{2}{*}{$\begin{array}{l}\text { Conc. } \\
\text { Enzima } \\
(\mathrm{mL} / \mathrm{Kg})\end{array}$} & \multirow{2}{*}{$\begin{array}{c}\text { Matéria seca* } \\
(\%)\end{array}$} & \multicolumn{3}{|c|}{$\begin{array}{l}\text { Fibras* } \\
(\mathrm{g} / 100 \mathrm{~g})\end{array}$} & \multirow{2}{*}{$\begin{array}{c}\text { Açúcares } \\
\text { solúveis totais } \\
\text { (g/100g)* }\end{array}$} & \multirow{2}{*}{$\begin{array}{c}\text { Amido } \\
(\mathrm{g} / 100 \mathrm{~g})^{*}\end{array}$} & \multirow{2}{*}{$\begin{array}{l}\text { Amilose } \\
(\mathrm{g} / 100 \mathrm{~g})^{*}\end{array}$} \\
\hline & & & & Insolúvel & Solúvel & Totais & & & \\
\hline $\begin{array}{l}\text { Matéria } \\
\text {-prima }\end{array}$ & & & $39,30 \pm 0,401$ & $5,13 \pm 0,030$ & $3,58 \pm 0,025$ & $8,71 \pm 0,055$ & $2,40 \pm 0,010$ & $88,91 \pm 0,001$ & $14,05 \pm 0,016$ \\
\hline \multirow{9}{*}{25} & \multirow{3}{*}{48} & 0 & 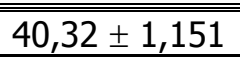 & $3,66 \pm 0,011$ & $3,48 \pm 0,012$ & $7,74 \pm 0,022$ & $1,1,97 \pm 0,009$ & $84,11 \pm 0,061$ & $13,99 \pm 0,024$ \\
\hline & & 1 & $40,88 \pm 1,416$ & $3,75 \pm 0,006$ & $3,64 \pm 0,008$ & $7,40 \pm 0,003$ & $1,86 \pm 0,007$ & $81,63 \pm 0,053$ & $14,12 \pm 0,009$ \\
\hline & & 2 & $39,07 \pm 1,785$ & $3,79 \pm 0,015$ & $2,42 \pm 0,006$ & $6,22 \pm 0,021$ & $1,69 \pm 0,006$ & $79,89 \pm 0,061$ & $13,02 \pm 0,016$ \\
\hline & \multirow{3}{*}{72} & 0 & $38,36 \pm 0,427$ & $4,08 \pm 0,005$ & $3,55 \pm 0,014$ & $7,63 \pm 0,018$ & $1,28 \pm 0,009$ & $80,58 \pm 0,053$ & $13,84 \pm 0,009$ \\
\hline & & 1 & $38,94 \pm 0,626$ & $4,10 \pm 0,005$ & $2,45 \pm 0,025$ & $6,56 \pm 0,020$ & $1,38 \pm 0,011$ & $75,53 \pm 0,053$ & $13,54 \pm 0,016$ \\
\hline & & 2 & $38,43 \pm 0,360$ & $4,10 \pm 0,008$ & $2,53 \pm 0,025$ & $6,63 \pm 0,033$ & $1,32 \pm 0,006$ & $75,11 \pm 0,053$ & $13,46 \pm 0,009$ \\
\hline & \multirow{3}{*}{96} & 0 & $37,31 \pm 0,632$ & $4,42 \pm 0,025$ & $3,53 \pm 0,030$ & $7,97 \pm 0,055$ & $1,27 \pm 0,003$ & $77,42 \pm 0,053$ & $13,97 \pm 0,016$ \\
\hline & & 1 & $36,85 \pm 0,564$ & $3,43 \pm 0,025$ & $2,46 \pm 0,009$ & $5,88 \pm 0,034$ & $0,21 \pm 0,002$ & $75,00 \pm 0,053$ & $13,85 \pm 0,009$ \\
\hline & & 2 & $37,92 \pm 0,761$ & $3,45 \pm 0,015$ & $2,51 \pm 0,005$ & $5,95 \pm 0,010$ & $1,13 \pm 0,011$ & $74,00 \pm 0,061$ & $13,75 \pm 0,016$ \\
\hline \multirow{9}{*}{30} & \multirow{3}{*}{48} & 0 & $35,50 \pm 0,408$ & $4,74 \pm 0,014$ & $3,53 \pm 0,007$ & $8,26 \pm 0,007$ & $1,43 \pm 0,003$ & $83,58 \pm 0,086$ & $13,97 \pm 0,016$ \\
\hline & & 1 & $35,76 \pm 2,012$ & $4,73 \pm 0,005$ & $2,46 \pm 0,009$ & $7,19 \pm 0,013$ & $1,18 \pm 0,002$ & $79,89 \pm 0,061$ & $12,71 \pm 0,009$ \\
\hline & & 2 & $36,14 \pm 1,480$ & $4,61 \pm 0,005$ & $2,47 \pm 0,007$ & $7,08 \pm 0,002$ & $0,69 \pm 0,010$ & $78,89 \pm 0,053$ & $13,57 \pm 0,018$ \\
\hline & \multirow{3}{*}{72} & 0 & $35,51 \pm 1,061$ & $4,75 \pm 0,005$ & $3,23 \pm 0,025$ & $7,97 \pm 0,020$ & $0,97 \pm 0,007$ & $81,42 \pm 0,053$ & $12,83 \pm 0,016$ \\
\hline & & 1 & $36,08 \pm 0,867$ & $4,34 \pm 0,020$ & $3,45 \pm 0,005$ & $7,79 \pm 0,015$ & $0,94 \pm 0,009$ & $80,42 \pm 0,086$ & $12,94 \pm 0,016$ \\
\hline & & 2 & $37,15 \pm 1,334$ & $4,12 \pm 0,027$ & $3,32 \pm 0,065$ & $7,44 \pm 0,092$ & $0,91 \pm 0,002$ & $77,63 \pm 0,053$ & $13,16 \pm 0,016$ \\
\hline & \multirow{3}{*}{96} & 0 & $34,71 \pm 0,590$ & $3,47 \pm 0,012$ & $2,33 \pm 0,023$ & $5,80 \pm 0,034$ & $1,03 \pm 0,004$ & $82,53 \pm 0,086$ & $13,26 \pm 0,016$ \\
\hline & & 1 & $36,91 \pm 2,952$ & $4,18 \pm 0,005$ & $3,57 \pm 0,010$ & $7,75 \pm 0,015$ & $0,74 \pm 0,007$ & $80,95 \pm 0,061$ & $13,86 \pm 0,016$ \\
\hline & & 2 & $35,84 \pm 1,078$ & $3,39 \pm 0,001$ & $3,06 \pm 0,001$ & $7,45 \pm 0,021$ & $0,64 \pm 0,006$ & $71,68 \pm 0,061$ & $13,94 \pm 0,016$ \\
\hline
\end{tabular}

$(*)$ Valores médios de três repetições \pm 0 erro padrão da média onde: $\quad$ e.p $=S / \sqrt{ } \quad \quad S^{2}=\left(\Sigma X^{2}-(\Sigma X)^{2} / n\right) / n-1 \quad N=n^{0}$ de repetições 


\begin{tabular}{|c|c|c|c|c|c|c|c|c|c|}
\hline \multirow{2}{*}{$\begin{array}{c}\text { Tempe- } \\
\text { ratura } \\
\left({ }^{\circ} \mathrm{C}\right)\end{array}$} & \multirow{2}{*}{$\begin{array}{c}\text { Tempo } \\
\text { (h) }\end{array}$} & \multirow{2}{*}{$\begin{array}{c}\text { Conc. } \\
\text { Enzima } \\
(\mathrm{mL} / \mathrm{Kg})\end{array}$} & \multirow{2}{*}{$\begin{array}{c}\text { Matéria seca* } \\
(\%)\end{array}$} & \multicolumn{3}{|c|}{$\begin{array}{l}\text { Fibras* } \\
\text { (g/100g) }\end{array}$} & \multirow{2}{*}{$\begin{array}{c}\text { Açúcares } \\
\text { solúveis totais } \\
(\mathrm{g} / 100 \mathrm{~g})^{*}\end{array}$} & \multirow{2}{*}{$\begin{array}{c}\text { Amido } \\
(\mathrm{g} / 100 \mathrm{~g})^{*}\end{array}$} & \multirow{2}{*}{$\begin{array}{l}\text { Amilose } \\
(\mathrm{g} / 100 \mathrm{~g})^{*}\end{array}$} \\
\hline & & & & Insolúvel & Solúvel & Totais & & & \\
\hline \multirow{9}{*}{35} & \multirow{3}{*}{48} & 0 & $37,49 \pm 2,232$ & $4,72 \pm 0,027$ & $3,90 \pm 0,047$ & $8,62 \pm 0,021$ & $1,97 \pm 0,002$ & $82,16 \pm 0,053$ & $13,97 \pm 0,016$ \\
\hline & & 1 & $36,49 \pm 2,054$ & $4,92 \pm 0,016$ & $2,97 \pm 0,011$ & $7,89 \pm 0,026$ & $1,92 \pm 0,003$ & $79,68 \pm 0,061$ & $13,76 \pm 0,009$ \\
\hline & & 2 & $36,54 \pm 1,843$ & $4,77 \pm 0,015$ & $2,72 \pm 0,006$ & $7,49 \pm 0,021$ & $1,44 \pm 0,009$ & $73,32 \pm 0,053$ & $13,35 \pm 0,016$ \\
\hline & \multirow{3}{*}{72} & 0 & $34,65 \pm 1,244$ & $4,86 \pm 0,026$ & $1,53 \pm 0,025$ & $6,39 \pm 0,051$ & $1,06 \pm 0,021$ & $81,47 \pm 0,086$ & $14,07 \pm 0,009$ \\
\hline & & 1 & $34,86 \pm 1,403$ & $3,95 \pm 0,010$ & $2,73 \pm 0,020$ & $6,68 \pm 0,010$ & $1,02 \pm 0,012$ & $84,32 \pm 0,061$ & $13,75 \pm 0,016$ \\
\hline & & 2 & $35,59 \pm 1,227$ & $3,94 \pm 0,017$ & $2,71 \pm 0,009$ & $6,65 \pm 0,008$ & $0,95 \pm 0,007$ & $85,05 \pm 0,086$ & $13,70 \pm 0,016$ \\
\hline & \multirow{3}{*}{96} & 0 & $33,55 \pm 1,636$ & $4,62 \pm 0,015$ & $2,31 \pm 0,009$ & $6,92 \pm 0,006$ & $0,73 \pm 0,006$ & $80,11 \pm 0,061$ & $13,24 \pm 0,016$ \\
\hline & & 1 & $34,89 \pm 1,243$ & $4,53 \pm 0,004$ & $3,57 \pm 0,008$ & $8,10 \pm 0,012$ & $0,73 \pm 0,006$ & $81,26 \pm 0,086$ & $13,37 \pm 0,016$ \\
\hline & & 2 & $36,44 \pm 1,259$ & $4,47 \pm 0,028$ & $3,49 \pm 0,010$ & $7,69 \pm 0,038$ & $0,70 \pm 0,003$ & $82,60 \pm 0,053$ & $13,54 \pm 0,016$ \\
\hline
\end{tabular}

(*) Valores médios de três repetições \pm 0 erro padrão da média onde: $\quad$ e.p $=S / \sqrt{ } n \quad S^{2}=\left(\Sigma X^{2}-(\Sigma X)^{2} / n\right) / n-1 \quad N=n^{0}$ de repetições 


\section{REFERÊNCIAS BIBLIOGRÁFICAS}

A.P.H.A. Compendium of for the microbiological examination of foods. Washington: s. ed., 1976, 702p.

ABE, M. O.; LINDSAY, R. C. Evidence for lactic streptococcal role in Nigerian acid cassava (Manihot esculenta Crantz). Journal of Food Protection, v.41, n.2. p.181184, 1978.

ADEGOKE, G. O.; BABALOA, A. K. Characteristics of microrganisms of importance in the fermentation of fou-fou and ogi, two Nigerian foods. Journal of Applied Bacteriology, v.65, n.4, p.449-453, 1988.

AKINRELE, I. A. Fermentation of cassava. Journal of the Science of Food Agriculture, v.15, n.5, p.589-594, 1964.

ALMEIDA, P. F. DE Processamento e caracterização da puba. Campinas, 1992. 115p. Tese (Doutorado) - Faculdade de Engenharia de Alimentos, Universidade Estadual de Campinas.

ALMEIDA, P. F. et al. Microbiology of cassava fermentation for puba production. Preliminar findings. In: CONGRESSO BRASILEIRO DE MICROBIOLOGIA, 14., Viçosa, 1987. Resumos. Viçosa: Sociedade Brasileira de Microbiologia, 1987. p.45.

ALMEIDA, P. F.; MORAES, I. O.; CASTRO, R. C.; MENEZES, T. J. B. Fermentação da mandioca para produção da puba carimã. Ciência e Tecnologia de Alimentos, v.13, n.2, p.113-120, 1993. 
AMPE, F.; MALONGA, M.; KÉLÉLÉ, S. A.; MAVOUNGOU, O.; BRAUMAM, A. Retting: a lactic fermentation of cassava./ Apresentado ao International Congress On Lactic Bacteria Lactic, 1991/

AMPE, F.; BRAUMAM, A. Origin of enzymes involved in detoxification and softening during cassava retting. World Journal of Microbiology and Biotechnology, v.11, n.2, p.178-182, 1995.

AMPE, F; BRAUMAN, A.; TRÈCHE, S.; AGOSSOU, A. Cassava retting: optimisation of a traditional fermentation by an experimental research methodology. Journal of Science of Food Agriculture, v.64, n.4, p.355- 361, 1994.

ASP, N. G.; JOHANSSON, C. G; HALLMER, H.; SILJESTRÖM, M. Enzymatic assay of insoluble and soluble dietary fiber. Journal of Agriculture and Food Chemistry, v.31, n.3, p.476-482, 1983.

ASSOCIAÇÃO BRASILEIRA DE PRODUTORES DE AMIDO E MANDIOCA. http.//www.abam.com.br. (23 mar. 2001)

ASSOCIATION OF OFFICIAL ANALYTICAL CHEMISTS. Official methods of analysis. 16.ed. Arlengton: A.O.A.C., 1995.

AYERNOR, G. S. Effects of the retting of cassava on product yield and cyanide detoxfication. Journal Food Tecnology, v.20, n.4, p.89-96, 1985.

AYRES, J. C. Manioc: the potential exists for increase use of this tropical plant and its products. Food Technology, v.26, n.3, p. 128-138, 1972.

BALAGOPALAN, C.; PADMAJA, G.; NANDA, S. N. Cassava in food, feed and industry. Boca Raton: CRC Press, 1988. 
BOKANGA, M.; O'HAIR, S. K.; NARAYANAN, K. R.; STEINKRAUS, K. H. Cyanide detoxification and nutritional changes during cassava (Manihot esculenta Crantz) fermentation, In: SYMPOSIUM OF THE INTERNATIONAL SOCIETY FOR TROPICAL ROOT CROPS. 8., Bangkok, 1990. Proceedings. Bangkok: R. H. Howler, 1990. $385 p$.

BOKANGA, M.; STEINKRAUS, K. H. Essential microrganisms, physical and biochemical changes occurring in African indigenous cassava (Manihot esculenta Crantz) root fermentation./ Apresentado ao ANNUAL MEETING OF INSTITUTE OF FOOD TECNOLOGISTS, New Orleans, 1988/

BRAUMAN, A.; MALONGA, M.; MAVOUNGOU, O.; THĖCHE, S.; KÉLÉKÉ, S.; AMPE, F; MIAMBI E. Kinetic study of retting: a cassava traditional fermentation in Central Africa. WORKSHOP AVANCES SOBRE ALMIDON DE YUCA, Cali, 1991. p. 17-20.

BRAUMAN, A.; MALONGA, M.; MAVOUNGOU, O.; TRÈCHE, S.; KÉLÉKÉ, S.; AMPE, F.; MIAMBI, E. Étude cinétique du roussage tradicionnel des racines de manioc en Afrique Centrale (Congo). Transformation Alimentaire du Manioc. Paris: ORSTOM, 1995. p.287-305.

CALL, H. P.; WALTER, J.; EMEIS, C. C. Maceration activity of exo and endo poligalacturonase from Candida macedoniensis. Journal of Food of Biochemistry, v.9, n.4, p.325-348, 1985.

CÂMARA, G. M. de S.; GODOY, O. P.; FILHO, J. M.; LIMA, U. de A. Mandioca: produção, pré-processamento e transformação agro-industrial. São Paulo: Secretaria da Indústria, Comércio, Ciência e Tecnologia, 1982. 79p. (Série Extensão Agroindustrial, 4)

CAMARGO, C.; COLONNA, P.; BULEON, A.; RICHARD-MOLLARD, D. Funcional properties os sour cassava (Manihot utilissima) starck: polvilho azedo. Journal Science Food Agriculture, v.45, n.2, p.273-280, 1988. 
CEREDA, M. P. Alguns aspectos sobre a fermentação da fécula de mandioca. Botucatu. 1973. 89p. Tese (Doutorado) - Faculdade de Ciências Médicas e Biológicas de Botucatu, Universidade Estadual Paulista Júlio de Mesquita Filho.

CEREDA, M. P.; BONASSI, I. A.; BRASIL, O. G.; MATSUI, E. Fermentation of cassava starch different cultivation condidions. Revista Brasileira de Mandioca, v.3, n.1, p.69-74, 1985.

CHADHA, K. K.; NAIR, G. G. Advances in horticulture. New Delhi: Malhotra, 1994. (Tuber Crops, 8)

CODNER, R. C. Pectinolytic and cellulolytic enzymes in the microbial modification of plant tissue. Journal of Applied and Bacteriology, v.34, n.1, p.147-160, 1971.

COLLARD, P.; LEVI, S. A. A two-stage fermentation of cassava. Nature, v.183, n.4661, p.620-621, 1959.

DUBOIS, M; GILLES, K. A.; HAMILTON, J. K.; REBES, P.A.; SMITH, F. Colorimetric method for determination of sugar and related substances. Analytical Chemistry, v.28, n.3, p.350-356, 1956.

EZEALA, D. O. Changes in the nutricional quality of fermented cassava tuber meal. Journal of Agriculture and Food Chemistry, v.32, p.467-472, 1984.

FNP CONSULTORIA E COMÉRCIO. AGRIANUAL 99: Anuário da Agricultura Brasileira. São Paulo, 1999. p.352-358.

FRAZIER, W. C. Food microbiology. 3.ed. New York: Mc Graw Hill, 1978. 537p.

GEORGE, M., PADMAJA, G.; MOORTHY, S. N. Enhancement in starch extractability from cassava (Manihot esculenta, Cranz) tuber through fermentation with a mixed culture inoculum. Journal Root Crops, v.17, n.1, p.1-9, 1991. 
GEORGE, M.; MOORTHY, S. N.; PADMAJA, G. Biochemical changes in cassava tuber during fermentation and its effect on extracted starch and residue. Journal of Science of Food and Agriculture, v.69, n.3, p.367-371, 1995.

GEORGE, M.; PADMAJA, G.; MOORTHY S. N. Enhancemente of starch extractability from cassava (Manihot esculenta Crantz) tubers through fermentation with a mixed culture inoculum. Journal Root Crops, v.17, n.1, p.1-19, 1992.

GEORGE. M. Varietal response of cassava roots to bulk fermentation with a mixed culture inoculum. Journal of Root Crops, v.20, n.1, p.117-124, 1994.

GRAVATÁ, A. G. Mandioca forever, carimã e povilho azedo. Chácaras e Quintais, v.62, p.440-441, 1940.

INTERNATIONAL ORGANIZATION FOR STANDARDIZATION. Norme internationale: Riz-détermination de la teneur en amylose.,1987. 5p. (ISO 6647)

KAY, D.E. Tropical productt digest. London: TDRI, 1987.

KETIKU, A. O.; AKINYELE, I. O.; KESHINRO, O. O.; AKINNAWO, O. O. Changes in the hydrocyanic acid concentration during traditional processing of cassava into "gari" and "lafum". Food Chemistry, v.3, n.2, p.221-226, 1978.

KITAGAWA, R. Influência de celulase, pectinase e hemicelulase na textura do palmito (Euterpe edulis Mart.). Piracicaba, 1991. 96p. Dissertação (Mestrado) - Escola Superior de Agricultura "Luiz de Queiroz", Universidade de São Paulo.

LANCASTER, P. A., INGRAM,J. S., LIM, M. Y.; COURSEY, D. G. Traditional cassava based foods: survey of processing techniques. Economic Botany, v.36, n.1, p.1245, 1982. 
LONGE, O. G., Effect of processing on the chemical composition and energy value of cassava. Nutrition Reports International, v.21, n.6, p.819-828, 1980.

LORENZI, J. O.; DIAS, C. A .C. Cultura da mandioca. Campinas: Coordenadoria de Assistência Técnica, p.7, 1993.(Boletim Técnico CATI, 211)

MALTA. A. Cultura da mandioca. Boletim de Agricultura - Departamento de Produção Vegetal - UFMG, v.7, p.45-52, 1958.

MARAVALHAS, N. Cinco estudos sobre farinha de mandioca. Manaus: INPA, 1964. 9p.

MARIATH, M. M. R.; RIVIERA, F. A. O consumo de mandioca e os riscos relacionados com o fatores tóxicos. Ciência, Cultura e Saúde. v.8, p.1-43, 1986.

MARTINEZ, A.; QUIROGA, M. C. Study of some physicochemicall properties of cassava starch during fermentation. Technologia, v.28, n.1, p.23, 1988.

Mc CLENDON, J. H., SOMMERS, G. F. The enzimatic of plant tissues. observations using a new method of measurement. Americam Jounal of Botany, v.47, n.1, p.1-7, 1960.

MENDES, B. A.; MORAES, I. O.; MAUGERI, F. F. Estudo comparativo entre as propriedades características da puba, polvilho azedo e mandioca moída visando aplicações em panificação e produção de etanol. In: CONGRESSO BRASILEIRO DE CIÊNCIA E TECNOLOGIA DE ALIMENTOS, 11., Recife, 1988. Anais. Recife: SBCTA, 1988. 141p.

MENEZES, T. J. B.; SARMENTO, S B. S.; DAIUTO, E.R. Fermentação da mandioca: natural e acelerada por enzimas. In: CONGRESSO BRASILEIRO DE CIÊNCIA E TECNOLOGIA DE ALIMENTOS, 16., Rio de Janeiro, 1998. Anais. Rio de Janeiro: SBCTA, 1998. p.1489-1492. 
MENEZES, T. J. B.; SARMENTO, S. B. S.; DAIUTO, E. R. Influência de enzimas de maceração na produção de mandioca puba, 1999. 35p. (Relatório Fapesp $96 / 07883-8)$

MEUSER, F. Cassava flours and starches: some considerations. In: WEBER, E. J.; COCK, J. H. AND CHOUINARD, A. Cassava Harvesting and Processing. Toronto: IDRC, 1978. 37p.

MEUSER, F.; SMOLNIK, H. D. Processing of cassava to gari and other foot stuffs. Starch/Starke, v.32, n.2, p.116-122, 1980.

MOORTHY, S. N.; GEORGE, M. Cassava fermentation and associated chances in physicochemical and funcional properties. Critical Reviews in Food Science and Nutrition, v.38, n.2, p.73-121, 1998.

MOORTHY, S. N.; GEORGE, M.; PADMAJA, G. Functional properties of the starchy flour extract from cassava on fermentation with a mixed culture inoculum. Journal of Science of Food and Agriculture, v.61, n.4, p.443, 1993.

NANDA, S. K.; GEORGE, M. Physical aspects of softening of cassava tubers upon fermentation with a mixed culture inoculum. Journal of Food Engineering, v.29, n.2, p.129-137, 1996.

NORONHA, E. S. Mandioca tem variada aplicação. Guia Rural, 1966/1967, p.240-244.

NOVO NORDISK FERMENT Ltd. Enzyme Business, Pectinex ULTRA SP-L, s.I., 1997. 4p.

NUMFOR, F. A.; WALTER, W. M. Jr.; SCHWARTZ, S. J. Physicochemical changes in cassava starch and flour associated whith fermentation: effect on textural properties. Starch/Starke, v.47, n.3, p.86-91, 1995. 
OGUNSUA, O. A. Changes in some chemical constituents during the fermentation of cassava roots (Manihot esculenta Crantz). Food Chemistry, v.5, n.3, p.249-255, 1980.

OHOCHUKU, N. S.; BALLANTINE, J. A. Fermented Cassava: odor active components. Journal Agriculture Food Chemistry, v.31, p.1386-1387, 1983.

OKAFOR, N.; IJIOMA, B.; OYOLU, C. Studies on the microbiology of cassava retting for foo-foo production. Journal of Applied Bacteriology, v.56, n.1, p.1-13, 1984.

OKECHUKWU, P. E.; OKAKA, J. C. ; AWAN, J. A. Preliminary investigation innto the effect of aeration, acidity and chip size on the fermentation of cassava for foo-foo production. Nigerian Food Journal, v.2, n.2, p.145, 1984.

OKEZIE, B. O.; KOSIKOWKI, F. V. Cassava as a food. Critical Reviews in food and nutrictial. Boca Raton: CRC Press, 1982. 285p.

OKOLIE, N. P.; IBEH, I. N.; UGOCHUKWU, F. N. Pruducion of improve cassava fou-fou, "akpu", through controllrd fermentation. Food Chemistry, v.44, n.2, p.137, 1992.

OLIVIERI, D. A.; SARMENTO, S. B. S.; MENEZES, T. J. B. Transformação na textura durante a fermentação de mandioca para a produção de puba. IN: SIMPÓSIO INTERNATIONAL DE INICIAÇÃO CIENTÍFICA DA USP/ESALQ, 7., Piracicaba, 1999. Resumos. Piracicaba: ESALQ, 1999.

OYENUGA, V. A. Nigeria's food and feeding stuffs. s.I.: University Press, 1968. p.20-27.

OYEWOLE, O. B. Cassava processing in Africa. In: Application of biotechnology to traditional fermented food. Washington: National Research Council, 1992. p.8992. (Repport of an ad-hoc panel of the board on size an technology for international development) 
OYEWOLE, O. B. Optimization of cassava fermentation for fufu production: effects of single starter cultures. Journal of Appied Bacteriology, v.68, n.1, p.49-54, 1990.

OYEWOLE, O. B.; ODUNFA, S.A. Characterization and distribuition of lactic acid bactéria in cassava fermentation during fou-fou production. Journal of Applied Bacteriology, v.68, n.3, p.145-152, 1990.

OYEWOLE, O. B.; ODUNFA, S.A. Effect of fermentation on the carbohydrate, mineral and protein contents of cassava during "foo foo" production. Journal of Food Composition and Analisis, v.2, n.4, p.170-176, 1989.

OYEWOLE, O. B.; ODUNFA, S.A. Microbiologial studies on cassava fermentation for "lafum" production. Food Microbiology, v.5, n.2, p.125-133, 1988.

PADMAJA, G.; BALOGOPALAN C. Effect of molasses and urea on silage fermentaction of cassava tubers. Tropical Science, v.31, n.4, p.257-264, 1991.

PHAN, T. H.; MERCIER, C. Improvement of the composition and the texture of the tradicional Africa meal "foofoo" by adding monoglycerides to cassava (Manihot esculenta). Sciences des Aliments, v.4, n.2, p.109-120, 1984.

PREGNOLATO, W.; PREGNOLATO, N. P. Normas analíticas do Instituto Adolfo Lutz. 3. ed. São Paulo: Instituto Adolfo Lutz, 1986. 533p.

PRESCOTT, S.C.; DUNN,C.G. Industrial microbiology. 3.ed. New York: McGraw-Hill Book, 1959. 945p.

RICHARD, J. E.; BEHN, K. R. Avaliation of acid and enzyme hidrolytic methods for the determination African of cassava starch. Journal of Science of Food and Agriculture, v.41, n.4, p.373-379, 1987. 
SHARMA, A.; JOSEPH, R. Studies of the aplication of plant cell wall degrading enzymes from Aspergillus terreus and Neurospora crassa. Biotecnology Letters, v.7, n.5, p.481-486, 1983.

SOMOGY, M. Determination of blood sugar. Journal of Biological Chemistry, n.160, p.61-68, 1945.

SREENATH, H. K.; FREY, M. D.; RADOLA, B. J. Degradation of a washed carrot preparations by cellulase and pectinases. Biotechnlogy and Bioteengineering, v.26, n.7, p.788-796, 1984.

TINAY, A. H.; BURENG, P. L.; YAS, A. E. Hydrocyanic levels in fermented cassava Journal of Food Technology, v.19, n.3, p.297-202, 1984.

ZETELAKI-HORVATH, K.; GATAI, K. Application of endo-poligalacturonase to vegetables and fruits. Acta Alimentaria, v.6, n.4, p.355-376, 1977. 